CONTEXTO DEPOSICIONAL E DIAGÊNESE DE ROCHAS NEOPROTEROZÓICAS (FORMAÇÃO SERRA SANTA HELENA) A PARTIR DA COMPOSIÇÃO E ÍNDICE DE KÜBLER: INFLUÊNCIA DA MOAGEM DAS AMOSTRAS

DISSERTAÇÃO № 372

LUCAS FREYER SAMPAIO 
UNIVERSIDADE DE BRASÍLIA - UNB

INSTITUTO DE GEOCIÊNCIAS - IG/UNB

\title{
CONTEXTO DEPOSICIONAL E DIAGÊNESE DE ROCHAS NEOPROTEROZÓICAS (FORMAÇÃO SERRA SANTA HELENA) A PARTIR DA COMPOSIÇÃO E ÍNDICE DE KÜBLER: INFLUÊNCIA DA MOAGEM DAS AMOSTRAS
}

\author{
DISSERTAÇÂO № 372
}

LUCAS FREYER SAMPAIO

BANCA EXAMINADORA

Prof ${ }^{\mathrm{a}}$.Dr ${ }^{\mathrm{a}}$. Edi Mendes Guimarães (Orientadora - IG-UnB)

Prof. Dr. Carlos José Souza de Alvarenga (IG-UnB)

Dr ${ }^{\text {a }}$. Camila Wense Dias dos Anjos (Petrobrás)

Prof. Dr. José Elói Guimarães Campos (Suplente - IG-UnB) 


\section{AGRADECIMENTOS}

Agradeço à minha orientadora, pelos conselhos, discussões e cobranças, sempre na hora certa.

À minha família, pelo apoio.

Aos meus colegas de laboratório e amigos, Rafael, Laura, Gabi e outros, pelas horas de discussão, trabalho conjunto e farra.

À minha esposa Janice, pela paciência e carinho.

À todos, muito obrigado. 


\section{RESUMO}

O Grupo Bambuí compreende uma sequência de rochas carbonáticas e terrígenas de idade neoproterozoica que constitui extensa área da região central do Brasil, constituindo parte da Faixa de Dobramentos Brasília e estendendo-se sobre o Cráton do São Francisco. Numerosos trabalhos têm estudado variados aspectos desta unidade, no entanto, sem se aprofundar no conhecimento da composição das rochas siliciclásticas, relevante para a interpretação paleoambiental e pósdeposicional. Buscando contribuir com a construção do conhecimento de sua história deposicional e diagenética e posteriores influências tectônicas, este trabalho tem como objetivo apresentar o significado deposicional e diagenético da composição mineral e das características cristalográficas, químicas e petrográficas das rochas siliciclásticas da Formação Serra de Santa Helena (Grupo Bambuí) ao longo de um transecto W-E. Este é traçado desde a região goiana de Padre Bernardo (meridiano 48 ${ }^{\circ} 30$ ), nas proximidades da zona interna da Faixa de Dobramentos Brasília (FDB), até a Serra de São Domingos (meridiano 4650) no estado de Minas Gerais, limite entre a zona externa da FDB e a zona cratônica. Por geoquímica e petrografia foi possível inferir o ambiente tectônico-deposicional e as rochas presentes na área-fonte dos sedimentos constituintes da Formação Serra de Santa Helena como, respectivamente, orógeno reciclado e terrenos formados por rochas máficas-intermediárias, com contribuição de sequências sedimentaresmetassedimentares. A decomposição do pico $\mathrm{d}(001)$ dos difratogramas de raios $\mathrm{x}$, associada com a análise da largura à meia altura, indicou condições de diagênese para as rochas da Formação Serra de Santa Helena. O estágio diagenético alcançado pela Formação Serra de Santa Helena é mais alto quanto mais próximo do centro do orógeno, que chega à anquizona, evidenciando a influência dos esforços tectônicos sobre a cristalinidade da illita. É também possível que haja contribuição das nappes do Grupo Canastra, evidenciando que a carga tectônica exerceu influência sobre a cristalinidade dos argilominerais. Exceções constituem zonas de falhas, onde o calor gerado pelo movimento pode elevar a cristalinidade dos argilminerais.

Palavras-Chave: Grupo Bambuí; illita; cristalinidade; proveniência. 


\begin{abstract}
The Bambuí Group comprises a sequence of neoproterozoic carbonatic and terrigenous rocks outcropping in a vast area of central Brazil, constituting part of the Brasilia Fold Belt and extending over the São Francisco Craton. Numerous researchers have studied various aspects of this unit, however, without delving into the composition of siliciclastic rocks, relevant to the paleoenvironmental and post-depositional interpretation. Aiming to contribute to the construction of knowledge about depositional and diagenetic history and subsequent tectonic influences over the sedimentary sequences of Bambuí Group, this work aims to present the mineral, crystallographic, chemical and petrographic characteristics to infer the depositional context and diagenetic conditions of siliciclastic rocks of Serra de Santa Helena Formation (Bambuí Group) along a W-E transect. This section extends from Padre Bernardo (Goiás state, meridian $48^{\circ} 30$ ), near the inner zone of the Brasilia Fold Belt (Faixa de Dobramentos Brasília - FDB) to the Serra de São Domingos (meridian $46{ }^{\circ} 50$ ) in the state of Minas Gerais, limit between the outer zone of the FDB and the cratonic domain. Using data from geochemistry and petrography analysis was possible to infer the tectonic-depositional setting and the litotypes present in the source area as, respectively, recycled orogen and sequences formed by mafic-intermediate rocks with contribution of sedimentary-metasedimentary origin. The decomposition of the X-ray diffraction patterns, associated with the analysis of the width at half maximum, indicated diagenetic conditions for rocks of the Bambuí Group. The diagenetic stage reached by the Serra de Santa Helena Formation is higher the closer to the center of the orogen, showing the influence of tectonic stress on illite crystallinity. It is also possible that there is contribution from nappes of the Canastra Group. Exceptions are fault zones, where the heat generated by the movement can increase the clay mineral crystallinity.
\end{abstract}

Keywords: Bambuí Group; illite; crystallinity; provenance. 


\section{Sumário}

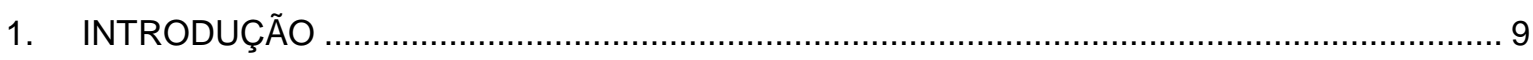

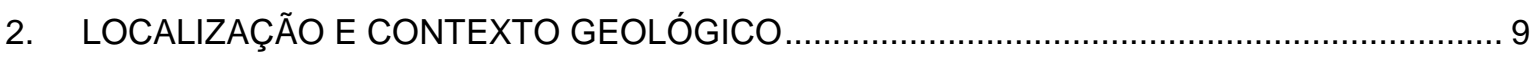

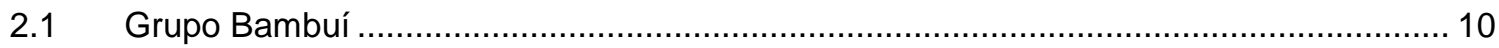

3. ROCHAS SEDIMENTARES: EVOLUÇÃO DO CONHECIMENTO PARA INTERPRETAÇÃO DE PROVENIÊNCIA, CONTEXTO DEPOSICIONAL E DIAGÊNESE ....................................... 12

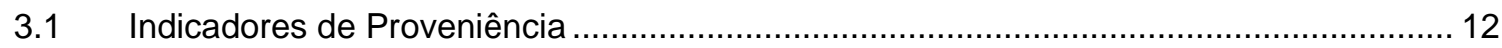

3.1.1 Considerações gerais sobre grauvacas .......................................................... 13

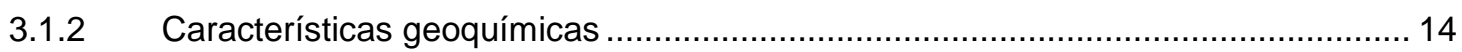

3.1.3 Significado das Grauvacas ......................................................................... 14

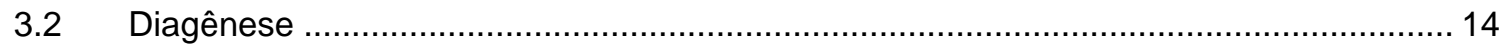

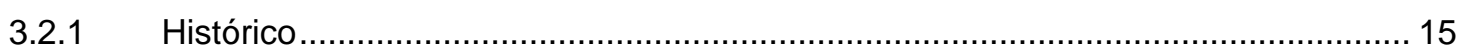

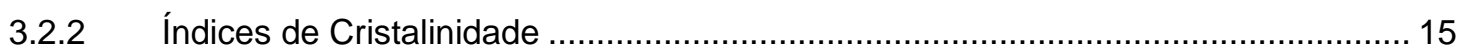

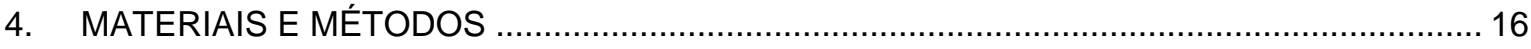

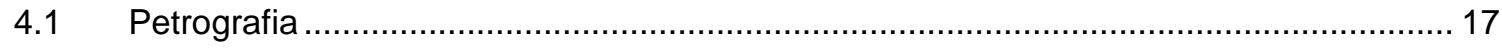

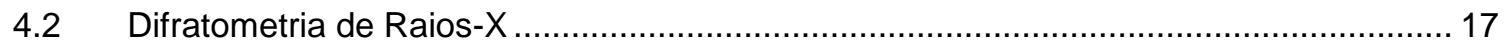

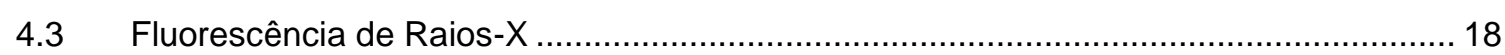

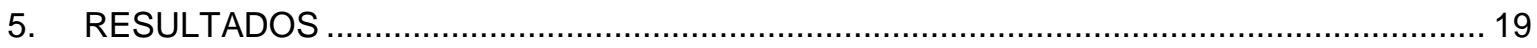

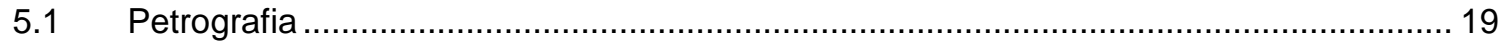

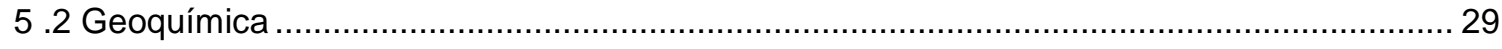

5.3 Desagregação das amostras e separação dos argilominerais ....................................... 33

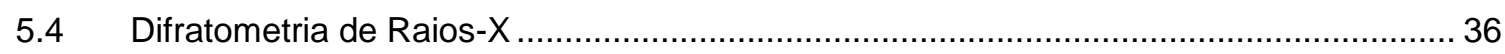

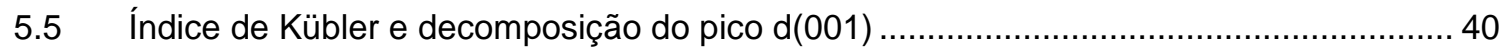

6 DISCUSSÃO: CONDIÇÕES DEPOSICIONAIS E DIAGENÉTICAS DA FORMAÇÃO SERRA DE SANTA HELENA, COM BREVES CONSIDERAÇÕES SOBRE A INFLUÊNCIA DA DESAGREGAÇÃO DE AMOSTRAS E A DETERMINAÇÃO DO ÍNDICE DE KÜBLER. ................. 43

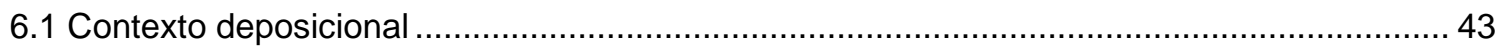

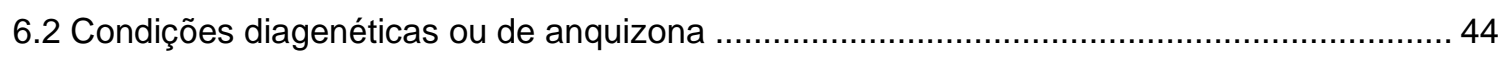

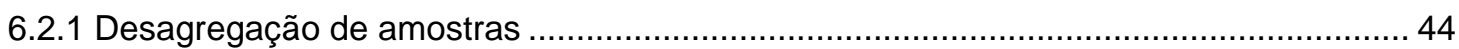

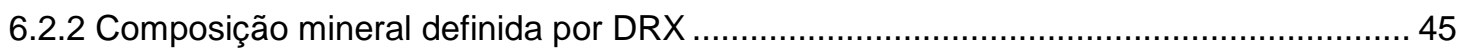

6.2.3 Decomposição da reflexão 001 da illita/moscovita e Determinação do Índice de Kübler

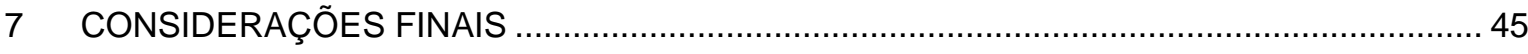

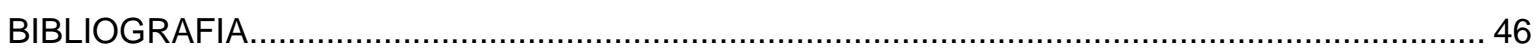

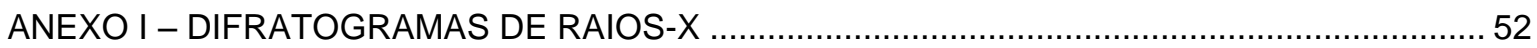


Índice de Figuras

Figura 1 - Mapa geológico da área em estudo, mostrando também os locais de amostragem e as colunas estratigráficas de estudos realizados na região. Adaptado de Lacerda Filho et al. (2004) e Alvarenga et al. (2007). 10

Figura 2 - Moinho Micronizador McCrone. Observar o recipiente para colocação da amostra (1) e as peças de ágata utilizadas na moagem (2) ...................................................................... 17

Figura 3 - Morteiro (1), peças de moagem de coríndon (2) e peneira (3)................................... 17

Figura 4 - Arenito muito fino com marcas onduladas. Formação Serra de Santa Helena próximo à Serra de São Domingos-MG, ponto 14-II-56.

Figura 5 - Arenito muito fino. Observar o formato lenticular de algumas camadas, caracterizando estruturas tipo hummocky. Fm. Serra de Santa Helena próximo à Serra de São Domingos-MG, ponto LS-004.

Figura 6 - Camadas mais espessas, no centro da foto, correspondem aos arenitos muito finos, enquanto as mais finas correspondem a ritmitos compostos por siltitos e arenitos muito finos. Fm. Serra de Santa Helena próximo à Serra de São Domingos-MG, ponto LS-005......

Figura 7 - Classificação petrográfica de Pettijohn et al. (1972). As amostras são classificadas como grauvacas líticas. Qt - Quartzo total; F - Feldspatos; L - Fragmentos líticos.

Figura 8 - Diagrama de Dickinson et al. (1983) mostrando a proveniência dos sedimentos que compõem os arenitos de acordo com a composição mineralógica. Qt - Quartzo total; F Feldspatos; $L$ - Fragmentos líticos.

Figura 9 - No centro da foto, grão de quartzo arredondado (Nicóis cruzados, Ponto 13-V-1) ...... 23

Figura 10 - No centro da foto, grão de plagioclásio exibindo macla polissintética (lei da albita) (Nicóis cruzados, ponto LS-004). Qtz - Quartzo; PI - Plagioclásio.

Figura 11 - No centro da foto, grão de microclínio límpido, exibindo característica macla "tartan" (Nicóis cruzados, ponto LS-006). Qtz - Quartzo; Kfs - Feldspato potássico; Ms - Muscovita....... 23

Figura 12 - Grão de feldspato parcialmente alterado para illita (PI 1), no qual as palhetas de illita se desenvolveram nos planos de clivagem. Há também um grão de feldspato completamente alterado (PI 2). PI - Plagioclásio.

Figura 13 - Palheta de muscovita detrítica (indicada pela seta) deformada por compactação (Nicóis cruzados, ponto 12-IV-78).

Figura 14 - No centro da foto, palheta de clorita detrítica indicada pela seta (Nicóis paralelos, ponto LS-003).

Figura 15 - Destacada nas duas imagens, palheta de biotita detrítica vista sob nicóis paralelos (esquerda) e cruzados (direita) (ponto 12-IV-78)......

Figura 16 - Cristais euédricos de pirita, exibindo coloração amarelo clara (destacados pelas setas) (Luz refletida sob nicóis paralelos, ponto LS-002).

Figura 17 - Palhetas de vermiculita vistas em nicóis paralelos (esquerda) e cruzados (direita), indicadas pelas setas (ponto LS-008a).

Figura 18 - Vermiculita indicada pela seta. Observar o desenvolvimento preferencial das palhetas ao longo do que possivelmente eram os planos de clivagem do anfibólio (Nicóis paralelos, ponto LS-008a) 26 
Figura 19 - Grão de quartzo (destacado pela seta) exibindo crescimento secundário de sílica (Nicóis cruzados, ponto 12-IV-78)...

Figura 20 - Cimento ferruginoso substituindo grãos de variados minerais e porções da matriz (Nicóis paralelos, ponto 11-III-84).

Figura 21 - Deformação sin-sedimentar. Observar a variação no conteúdo de argila das lâminas, evidenciada pela mudança de cor (Nicóis paralelos, ponto LS-005).

Figura 22 - Superfície de erosão marcando o limite entre laminações (laminação cruzada) (Nicóis paralelos, ponto LS-003).

Figura 23 - Acamamento gradacional. Observar a mudança brusca de granulometria ao passar de uma sequência para outra (Nicóis paralelos, ponto LS-001).

Figura 24 - Gráfico de $\mathrm{K}_{2} \mathrm{O} / \mathrm{Na}_{2} \mathrm{O}$ versus $\mathrm{SiO}_{2}$ (Roser \& Korsch 1986). MP - Margem Passiva; MCA - Margem Continental Ativa; ARC - Arco de llhas.

Figura 25 - Diagrama de TiO2 vs Fe2O3+MgO (Bathia 1983). MP - Margem Passiva; MCA Margem Continental Ativa; AIC - Arco de Ilhas Continental; AIO - Arco de llhas Oceânico............30

Figura 26 - Diagrama discriminante de Roser \& Korsch (1988).

Figura 27 - Diagrama discriminante de Bathia (1983). Os pontos se distribuem entre os campos de Arco de Ilhas Continental e Margem Continental Ativa

Figura 28 - Os asteriscos indicam a composição com o valor mínimo de CIA para variados tipos de rocha. A linha tracejada representa o trend de alteração. Os círculos vazios correspondem aos valores encontrados para as rochas da Fm. SSH. a) Gabro; b) Tonalito; c) Granodiorito; d) Granito; e) Granito tipo A; f) Charnoquito.

Figura 29 - Diagrama de classificação de Pettijohn. As amostras não alteradas se distribuem entre os campos de litarenitos e grauvacas.

Figura 30 - Comparação entre os valores de largura à meia altura das amostras preparadas com o Moinho McCrone e o morteiro. N - Fração argila orientada e seca ao ar; G - fração argila orientada e solvatada com etileno-glicol.

Figura 31 - Comparação entre os resultados do morteiro (superior) e McCrone (inferior) para a amostra LS-003 (altamente coesa). Chl - Clorita; III - Illita; Ms - Muscovita; Qtz - Quartzo; Alb Albita.

Figura 32 - Comparação entre os resultados do morteiro (superior) e McCrone (inferior) para a fração argila da amostra LS-001 (pouco coesa). Chl - Clorita; III - Illita; Ms - Muscovita; Qtz Quartzo; Alb - Albita.

Figura 33 - Difratograma de rocha total da amostra LS-004, representativo da mineralogia das amostras analisadas.

Figura 34 - Difratogramas da fração argila $(N)$, solvatada com etileno-glicol $(G)$ e aquecida $(A)$ da amostra 11-III-84.

Figura 35 - Difratograma de rocha total da amostra 11-II-78. Observar a reflexão do microclínio assinalada

Figura 36 - Difratogramas da fração argila $(N)$, solvatada com etileno-glicol $(G)$ e aquecida $(A)$ da amostra LFDF006.2. Observar a reflexão da esmectita assinalada. 
Figura 37 - Difratogramas da fração argila $(N)$, solvatada com etileno-glicol $(G)$ e aquecida $(A)$ da

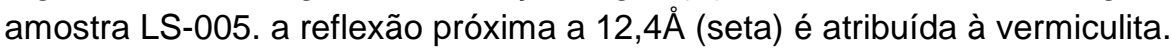

Figura 38 - Valores de FWHM, em ${ }^{\circ} \Delta 2 \theta$, de Bonhomme (1986) (quadrados) e deste trabalho (losangos)

Figura 39 - Decomposição da reflexão 001 da illita da fração argila da amostra 13-V-1. A linha azul representa 0 valor medido. A linha vermelha representa a linha calculada que melhor se ajusta à reflexão. As linhas pretas representam as reflexões após a decomposição.

Figura 40 - Valores de FWHM da fração argila $(\mathrm{N})$ versus valores de FWHM da argila solvatada com etileno-glicol (G)

Figura 41 - Variação do índice de Kübler de acordo com a distância do Orógeno. Valores de FWHM em ${ }^{\circ} \Delta 2 \theta$.

\section{Índice de Tabelas}

Tabela 1 - Compilação de análises químicas de grauvacas. (1) Kozlowsky et al. (2014) - média das análises; (2) Zimmermann (2005) - média das amostras COR; (3) Bauluz et al. (2000) - média de Quartzwackes Cambrianas; (4) El-Rahman et al. (2010) - amostra EGY-04-24; (5) Pettijohn (1957b) - Grauvaca arqueana, Manitou Lake, Ontario, Canada.

Tabela 2 - Valores dos limites da anquizona, em $\Delta 2 \theta$

Tabela 3 - Litotipos analisados. DRX - Difratometria de Raios-X; PTR - Petrografia; FRX Fluorescência de Raios-X. Observar exceção para as amostras LS-008, cuja zona UTM é 22S.. 16

Tabela 4 - Siglas padrão dos minerais citados neste trabalho, segundo Krets (1983). 19

Tabela 5 - Composição mineral identificada por petrografia 20

Tabela 6 - Resultados das análises por Fluorescência de Raios-X. P.F. - Perda ao Fogo; CIA Índice de Alteração Química

Tabela 7 - Largura à meia altura, em ${ }^{\circ} \Delta 2 \theta$, das amostras desagregadas com o Moinho McCrone e com morteiro, secas ao ar e tratadas com etileno-glicol. N - Fração argila orientada e seca ao ar; $G$ - Fração argila orientada e solvatada com etileno-glicol..

Tabela 8 - Minerais identificados na análise de rocha total e fração argila por DRX. N - Fração argila seca ao ar. Qtz - Quartzo; PI - Plagioclásio; Kfs - Feldspato potássico; Chl - Clorita; III Illita; Ms - Muscovita; Hem - hematita; Vrm - Vermiculita; Smc - Esmectita; M - constituinte maior; $m$ - constituinte menor; $\operatorname{tr}$ - constituinte traço. 36

Tabela 9 - Valores de FWHM após a decomposição. N - Fração argila seca ao ar; G - Fração argila solvatada com etileno-glicol. 


\section{INTRODUÇÃO}

As rochas sedimentares têm grande destaque, tanto no contexto acadêmico como no econômico. Seu estudo possibilita a descoberta de depósitos minerais de grande importância, como fosfato, calcário, evaporito, carvão e hidrocarbonetos, entre outros. No meio acadêmico, o estudo dessas rochas possibilita realizar inferências sobre o ambiente tectônico e sistema deposicional onde foram formados e depositados os sedimentos, clima, paleorrelevo, fauna e flora, viabilizando a construção de um panorama geral da época.

O Grupo Bambuí compreende uma sequência de rochas carbonáticas e terrígenas de idade neoproterozoica que constitui extensa área da região central do Brasil, constituindo parte da Faixa de Dobramentos Brasília e estendendo-se sobre o Cráton do São Francisco. Numerosos trabalhos têm estudado variados aspectos desta unidade, como a estratigrafia (Dardenne 1978, Alvarenga \& Dardenne 1978), depósitos minerais (Dardenne 1979 in Dardenne \& Schobbenhaus 2001), geologia estrutural e tectônica (Fuck 1994, Alkmim \& Martins-Neto 2001) e quimioestratigrafia de rochas carbonáticas (Santos et al. 1997, 2000; Alvarenga et al. 2007, 2012, 2014). Entretanto, o conhecimento da composição das rochas siliciclásticas, relevante para a interpretação paleoambiental e pós-deposicional (Guimarães \& Dutra 1969, Bonhomme 1976, Gomes 1988, Guimarães 1997, Campos 2013, Campos et al. 2015), é pouco desenvolvido. Na região do Distrito Federal e entorno a comparação da composição mineral das rochas siliciclásticas do Grupo Bambuí com as sequências subjacentes - Grupo Paranoá e Formação Jequitaí - evidencia a mudança de área-fonte dos sedimentos dessas unidades (Guimarães 1993, 1997). Enquanto aos sedimentos constituintes das rochas do Gr. Paranoá e Fm. Jequitaí atribui-se fonte cratônica, aos sedimentos imaturos, ricos em minerais ferro-magnesianos e em plagioclásio, do Gr. Bambuí foi associada área-fonte distinta, possivelmente exposta durante a Orogênese Brasiliana.

Buscando contribuir com a construção do conhecimento de sua história deposicional e diagenética e posteriores influências tectônicas, este trabalho tem como objetivo apresentar o significado deposicional e diagenético da composição mineral e das características cristalográficas, químicas e petrográficas das rochas siliciclásticas da Formação Serra de Santa Helena (Grupo Bambuí) ao longo de um transecto W-E. Este é traçado desde a região goiana de Padre Bernardo (meridiano 48 ${ }^{\circ} 30$ ), nas proximidades da zona interna da Faixa de Dobramentos Brasília (FDB), até a Serra de São Domingos (meridiano 4650) no estado de Minas Gerais, limite entre a zona externa da FDB e a zona cratônica.

\section{LOCALIZAÇÃO E CONTEXTO GEOLÓGICO}

A Faixa de Dobramentos Brasília (FDB), localizada na porção leste da Província Tocantins (Almeida et al. 1977; 1981), se formou durante a colisão continental entre os crátons Amazônico, São Francisco e Paranapanema (hoje encoberto pela bacia do Paraná) durante o Neoproterozoico, no evento conhecido como Orogenia Brasiliana. A FDB estende-se por aproximadamente $1100 \mathrm{~km}$ na direção NS, recobrindo parte dos estados de Minas Gerais, Goiás e Tocantins. É composta basicamente de quatro conjuntos litológicos (Pimentel et al. 2011). São eles:

i Espessa sequência de rochas sedimentares e metassedimentares, na porção leste da Faixa, depositados e deformados ao longo da margem oeste do Cráton São Francisco Congo. São agrupadas em sete unidades estratigráficas principais: grupos Paranoá, Araxá, Canastra, Ibiá, Vazante, Serra da Mesa e Bambuí;

ii O Maciço de Goiás, interpretado como um bloco crustal alóctone que consiste basicamente de terrenos Arqueanos; orógeno;

iii Complexo granulítico Anápolis Itauçu, interpretado como núcleo metamórfico do

iv Arco Magmático de Goiás, mais a oeste, descrito como uma associação Neoproterozóica de rochas vulcânicas e plutônicas de caráter juvenil. 
A área em estudo está localizada na porção leste da FDB, se estendendo até o limite com o Cráton São Francisco. Compreende dois domínios tectônicos: (i) Domínio não deformado, cujas rochas não foram afetadas pela orogênese; (ii) Domínio de embasamento não envolvido na deformação ou Zona Externa da FDB (Dardenne 1978, 2000), caracterizado pelas falhas reversas com vergência para leste (Figura 1).

$\mathrm{Na}$ área de estudo ocorrem as seguintes unidades: Grupo Paranoá, sequência psamopelítica que finaliza com um membro pelito carbonatado, sucedido pelo Grupo Bambuí, descrito em maior detalhe a seguir; sobrepostos tectonicamente sobre as duas unidades anteriormente citadas ocorrem os grupos Canastra (sequência metassedimentar de grau xisto verde) e Araxá (biotita e clorita-xistos) (Freitas-Silva \& Campos 1998).

\subsection{Grupo Bambuí}

Denominado inicialmente como Série Bambuí por Rimann (1917 in Dardenne 2000), foi descrito como uma sucessão de "xistos argilosos e argilas xistosas". Trabalhos posteriores (Costa \& Branco 1961, Barbosa 1965 e Braun 1968 in COMIG/CPRM 1999) adicionaram unidades siliciclásticas à base da Série, denominadas Formação Paranoá e Conglomerado (Formação) Samburá. Dardenne (1978) propõe a retirada da Formação Paranoá da base, elevando-a à categoria de Grupo, e caracteriza o Grupo Bambuí como sendo constituído pelas formações Jequitaí (base), Sete Lagoas, Serra de Santa Helena, Lagoa do Jacaré, Serra da Saudade e Três Marias (topo). Na Serra de São Domingos, onde aflora a sequência completa, o Grupo Bambuí é composto por cinco destas unidades, excetuando-se a da base (Alvarenga et al. 2012).

A Formação Sete Lagoas é composta por dolomitos cinza-claros com pseudomorfos de aragonita e estromatólitos, sucedidos por calcarenitos e calcilutitos intercalados por lâminas de argilito arroxeado, calcários com superfície de retrabalhamento por ondas de tempestade, calcarenitos e calcilutitos negros e por fim, no topo, dominam calcários. 


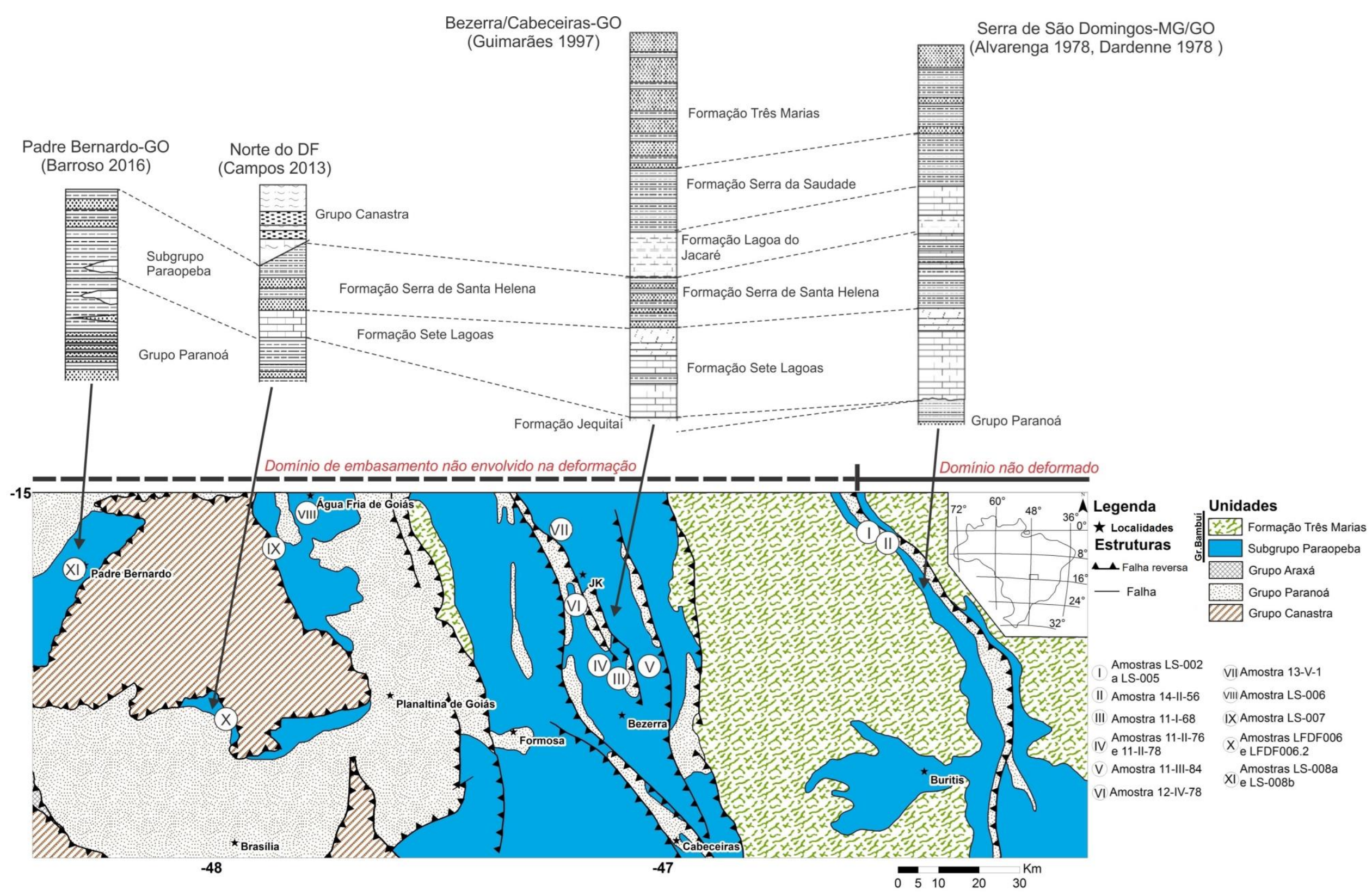

Figura 1 - Mapa geológico da área em estudo, mostrando também os locais de amostragem e as colunas estratigráficas de estudos realizados na região. Adaptado de Lacerda Filho et al. (2004) e Alvarenga et al. (2007). 
A Formação Serra de Santa Helena, objeto de estudo deste trabalho, consiste basicamente de intercalações de siltitos e grauvacas finas cinza-escuro esverdeadas com ocasionais estruturas de marca ondulada, hummocky e de carga. Na região de Formosa-GO, Guimarães (1997) descreve essa unidade como sendo constituída por arenitos com aproximadamente $40 \%$ de quartzo, 30 a $40 \%$ de feldspatos, 10 a $20 \%$ de filossilicatos, que podem chegar a $50 \%$ em rochas de granulometria mais fina, e quantidades inferiores a $10 \%$ de material não identificado e fragmentos líticos, que formam pseudomatriz. No norte do Distrito Federal, Campos (2013) descreve siltitos e arenitos muito finos com cores variando entre cinza escuro e cinza esverdeado, quando frescos. Quando alterados por intemperismo ocorrem nas cores roxo e amarelo. Os arenitos têm, em média, $30 \%$ de quartzo, $15 \%$ de feldspatos, $18 \%$ de filossilicatos, $4 \%$ de fragmentos líticos na forma de pseudomatriz e $34 \%$ de matriz.

Em contato transicional, a Formação Lagoa do Jacaré se inicia com intercalações de siltitos e siltitos calcíferos. Caracteriza-se por calcários e ocasionalmente bancos de calcarenitos, que são sucedidos por calcarenitos laminados, calcarenitos maciços, calcirruditos e calcilutitos com intercalações de lâminas argilosas pretas (Alvarenga et al. 2012).

A Formação Serra da Saudade se inicia logo acima do último nível carbonático da Formação Lagoa do Jacaré. Na sua base apresenta fácies síltico-argilosas, que gradam para camadas centimétricas de arenito fino com laminação cruzada, transicionando gradualmente para a formação superior (Alvarenga et al. 2012).

A Formação Três Marias, no topo do Grupo Bambuí, é constituída por bancos métricos de arenitos subquartzosos finos que se intercalam com siltitos, aumentando a granulometria para 0 topo (Alvarenga et al. 2012).

A denominação Subgrupo Paraopeba, utilizada em RADAMBRASIL (1982), se refere conjuntamente às formações Sete Lagoas, Serra de Santa Helena, Lagoa do Jacaré e Serra da Saudade, sendo aplicada também na ausência de uma ou mais destas unidades.

\section{ROCHAS SEDIMENTARES: EVOLUÇÃO DO CONHECIMENTO PARA INTERPRETAÇÃO DE PROVENIÊNCIA, CONTEXTO DEPOSICIONAL E DIAGÊNESE}

\subsection{Indicadores de Proveniência}

Há muito tempo se sabe que rochas sedimentares guardam, com elevado grau de fidelidade, características petrográficas, mineralógicas e geoquímicas da área-fonte. Cada ambiente tectônico gera uma pilha sedimentar com características distintas de maturidade dos sedimentos, bem como padrões distintos de elementos maiores, traço e terras raras. Esses dados, juntamente com estudos da estratigrafia e das rochas ígneas eventualmente intercaladas, permitem inferir com grande precisão o ambiente tectônico e o tipo de bacia onde se deu a deposição dos sedimentos.

Existem, na literatura, diversos trabalhos que utilizam a relação entre diferentes elementos maiores, traço e terras raras para realizar uma interpretação da rocha-fonte, do ambiente deposicional e das características desse ambiente (ex. Roser \& Korsch 1986, Bathia 1983, Bathia \& Crook 1986, Nesbit \& Young 1982, entre outros). A seguir são descritos alguns desses métodos.

O diagrama de classificação petrográfica com base na geoquímica de Pettijohn et al. (1987) permite diferenciar entre os grandes grupos de arenitos, não permitindo, no entanto, a diferenciação entre subtipos, como grauvaca lítica ou feldspática.

Os diagramas de Harker mostram a variação de elementos maiores $\left(\mathrm{MgO}, \mathrm{CaO}, \mathrm{Na}_{2} \mathrm{O}\right.$, $\mathrm{K}_{2} \mathrm{O}, \mathrm{FeO}$, etc) em relação ao conteúdo de $\mathrm{SiO}_{2}$. Estes diagramas mostram muito bem a evolução da maturidade dos sedimentos, com a diminuição dos elementos mais móveis e aumento dos mais imóveis em relação à sílica.

$\mathrm{O}$ diagrama de $\mathrm{K}_{2} \mathrm{O} / \mathrm{Na}_{2} \mathrm{O}$ versus $\mathrm{SiO}_{2}$ é um dos modos mais simples de determinar o ambiente tectônico onde se formaram os detritos que compõem uma rocha sedimentar. Foi apresentado por Middleton (1960) e posteriormente utilizado por Roser \& Korsch (1986) para distinção entre os ambientes de margem passiva, arco de ilhas e margem continental ativa (orógenos em geral).

$\mathrm{O}$ diagrama de $\mathrm{SiO}_{2} / \mathrm{Al}_{2} \mathrm{O}_{3}$ versus $\mathrm{K}_{2} \mathrm{O} / \mathrm{Na}_{2} \mathrm{O}$, (McLennan et al. 1990), assim como o anterior, possibilita a distinção entre margem passiva, arco de ilhas e margem continental ativa, 
porém permite também a distinção entre diferentes tipos de proveniência de zonas continentais, como interior cratônico e orógeno reciclado.

De modo semelhante aos anteriores, o diagrama de Ti versus $\mathrm{MgO}+\mathrm{Fe}_{2} \mathrm{O}_{3}$ (Bathia 1983) discrimina entre os ambientes de margem passiva, margem continental ativa, arco de ilhas continental e arco de ilhas oceânico.

Os diagramas discriminantes de Bathia (1983) e Roser \& Korsch (1988) expressam, respectivamente, o ambiente tectônico onde foram depositados os sedimentos e o tipo de rocha presente na área fonte. No diagrama de Bathia (1983), é possível discriminar as rochas entre os ambientes de Arco de llhas Oceânico (AIO), Arco de llhas Continental (AIC), Margem Continental Ativa (MCA) e Margem Continental Passiva (MCP, no entanto sedimentos depositados em bacias intracratônicas também plotam neste campo). Os pontos são plotados através das seguintes fórmulas:

$\mathbf{F} \mathbf{1}=-0,0447 \mathrm{SiO}_{2}-0,972 \mathrm{TiO}_{2}+0,008 \mathrm{Al}_{2} \mathrm{O}_{3}+0,208 \mathrm{Fe}_{2} \mathrm{O}_{3}-3,082 \mathrm{MnO}+0,140 \mathrm{MgO}+0,195 \mathrm{CaO}+$ $0,719 \mathrm{Na}_{2} \mathrm{O}-0,032 \mathrm{~K}_{2} \mathrm{O}+7,510 \mathrm{P}_{2} \mathrm{O}_{5}+0,303$

$\mathbf{F 2}=-0,421 \mathrm{SiO}_{2}+1,988 \mathrm{TiO}_{2}-0,526 \mathrm{Al}_{2} \mathrm{O}_{3}-1,61 \mathrm{Fe}_{2} \mathrm{O}_{3}+2,720 \mathrm{MnO}+0,881 \mathrm{MgO}-0,907 \mathrm{CaO}-$ $0,177 \mathrm{Na}_{2} \mathrm{O}-1,840 \mathrm{~K}_{2} \mathrm{O}+7,244 \mathrm{P}_{2} \mathrm{O}_{5}+43,57$

Já no diagrama de Roser \& Korsch (1988), são diferenciadas as rochas-fonte P1 (máficas com intermediárias subordinadas), P2 (intermediárias), P3 (félsicas) e P4 (recicladas/sedimentos quartzosos de proveniência continental). Os pontos são plotados usando as seguintes fórmulas:

$\mathbf{F} 1=-1,733 \mathrm{TiO}_{2}+0,607 \mathrm{Al}_{2} \mathrm{O}_{3}+0,760 \mathrm{Fe}_{2} \mathrm{O}_{3}-1,50 \mathrm{MgO}+0,616 \mathrm{CaO}+0,509 \mathrm{Na}_{2} \mathrm{O}-1,224 \mathrm{~K}_{2} \mathrm{O}-$ 9,09

$\mathbf{F} 2=0,445 \mathrm{TiO}_{2}+0,070 \mathrm{Al}_{2} \mathrm{O}_{3}-0,250 \mathrm{Fe}_{2} \mathrm{O}_{3}-1,142 \mathrm{MgO}+0,438 \mathrm{CaO}+1,475 \mathrm{Na}_{2} \mathrm{O}+1,426 \mathrm{~K}_{2} \mathrm{O}-$ 6,861

O Índice de Alteração Química (CIA - Chemical Index of Alteration, Nesbitt \& Young 1982) expressa 0 grau de alteração que o sedimento sofreu desde a rocha-fonte até sua deposição. Permite realizar inferências sobre o paleoclima da área-fonte e sobre a distância desta em relação ao ambiente deposicional. É dado pela equação $\left(\mathrm{Al}_{2} \mathrm{O}_{3} /\left[\mathrm{Al}_{2} \mathrm{O}_{3}+\mathrm{CaO}^{*}+\mathrm{Na}_{2} \mathrm{O}+\mathrm{K}_{2} \mathrm{O}\right]\right)^{*} 100$, onde $\mathrm{CaO}$ * representa todo o cálcio da rocha que não está contido em carbonatos. Valores entre 50 e 60 são considerados baixos, entre 60 e 80 intermediários e acima de 80 , altos, significando que se trata de sedimento muito maduro, ou mesmo que a própria rocha sedimentar sofreu alteração intempérica e, assim, interpretações dos elementos maiores podem levar a conclusões errôneas. Este pode ser associado ao gráfico ternário A-CN-K (Fedo et al. 1995) que, utilizando os trends de análises formados por amostras com diferentes graus de intemperismo, as associa com uma rocha inalterada original.

\subsubsection{Considerações gerais sobre grauvacas}

Grauvacas são, na definição mais clássica, rochas de cor cinza-escura ou preta, geralmente muito duras e litificadas. Diferentemente de outros tipos de arenitos, cujos grãos são unidos por algum tipo de cimento, nas grauvacas o material intergranular é composto por matriz fina de argilominerais, quartzo e feldspato (Pettijohn et al. 1987).

A proporção de grãos de quartzo, feldspato e fragmentos líticos é extremamente variável, porém predominam as rochas com maior proporção do primeiro componente. A descrição petrográfica de grauvacas é complicada devido à dificuldade na diferenciação entre matriz e fragmentos líticos após a modificação diagenética dos mesmos, o que pode levar a interpretações errôneas sobre ambiente tectônico e composição da rocha-fonte.

Quanto à classificação petrográfica, pode-se subdividir o grupo das grauvacas de acordo com o predomínio de feldspato (grauvacas feldspáticas ou arcoseanas) ou de fragmentos líticos (grauvacas líticas). Outra classificação é baseada na abundância de grãos de quartzo, segundo Crook (1970b): pobres em quartzo (<15\%), intermediárias (15-65\%) e ricas em quartzo (>65\%). 


\subsubsection{Características geoquímicas}

São características químicas das grauvacas a predominância de $\mathrm{MgO}$ sobre $\mathrm{CaO}$, de $\mathrm{FeO}$ sobre $\mathrm{Fe}_{2} \mathrm{O}_{3}$ e, principalmente, de $\mathrm{Na}_{2} \mathrm{O}$ sobre $\mathrm{K}_{2} \mathrm{O}$, característica esta que as diferenciam dos arcóseos. Para sedimentos com alto grau de maturidade, ou rochas sedimentares que tenham sofrido intemperismo químico moderado a alto, pode ocorrer uma inversão na relação do $\mathrm{Na}_{2} \mathrm{O}$ com $\mathrm{K}_{2} \mathrm{O}$. A composição química das grauvacas se aproxima mais daquela de um granodiorito do que de uma rocha máfica (basaltos e gabros) (tabela 1 ).

Tabela 1 - Compilação de análises químicas de grauvacas. (1) Kozlowsky et al. (2014) média das análises; (2) Zimmermann (2005) - média das amostras COR; (3) Bauluz et al. (2000) - média de Quartzwackes Cambrianas; (4) El-Rahman et al. (2010) - amostra EGY-0424; (5) Pettijohn (1957b) - Grauvaca arqueana, Manitou Lake, Ontario, Canada.

(1)

\begin{tabular}{ll}
\hline $\mathrm{SiO}_{2}(\%)$ & 74,17 \\
\hline $\mathrm{Al}_{2} \mathrm{O}_{3}$ & 12,18 \\
\hline $\mathrm{Fe}_{2} \mathrm{O}_{3}$ & 6,32 \\
\hline $\mathrm{MgO}$ & 1,69 \\
\hline $\mathrm{CaO}$ & 0,48 \\
\hline $\mathrm{Na}_{2} \mathrm{O}$ & 2,42 \\
\hline $\mathrm{K}_{2} \mathrm{O}$ & 1,89 \\
\hline $\mathrm{TiO}_{2}$ & 0,63 \\
\hline $\mathrm{P}_{2} \mathrm{O}_{5}$ & 0,14 \\
\hline $\mathbf{M n O}$ & 0,09 \\
\hline $\mathbf{P F}$ & 4,06
\end{tabular}

(2)

63,43

\begin{tabular}{lll}
4,17 & 63,43 & 7 \\
\hline 2,18 & 15,76 & 1 \\
6,32 & 6,07 & 3,6 \\
\hline, 69 & 2,3 & 2,4 \\
0,48 & 1 & 0,4 \\
\hline, 42 & 1,86 & 0,4 \\
1,89 & 4,01 & 3,4 \\
0,63 & 0,58 & 0,4 \\
0,14 & 0,16 & 0 \\
, 09 & 0,13 & \\
, 06 & 3,9 &
\end{tabular}

(3)

\subsubsection{Significado das Grauvacas}

Grauvacas representam sedimentos que foram erodidos, transportados por curtas distâncias e depositados rapidamente em ambiente marinho, de forma que não passaram por alterações químicas intensas. Em geral, são produtos de retrabalhamento, ou seja, gerados pela desestabilização de sedimentos em taludes. No entanto, nenhum turbidito da atualidade tem características semelhantes às das grauvacas, como por exemplo, a matriz abundante. Presumese então que boa parte da matriz seja oriunda da alteração diagenética de fragmentos líticos e minerais ferromagnesianos (Tucker 2001). Tal denominação também não pode ser associada a apenas um tipo de ambiente deposicional, tendo em vista que grauvacas são encontradas tanto em bacias do tipo foreland quanto em depósitos de margem passiva e sequências fluviais, entre outros.

\subsection{Diagênese}

A relação dos argilominerais com a diagênese tem sido tema de numerosos estudos nas últimas décadas. Weaver (1960 in Abad 2007) e Dunoyer de Segonzac (1969) publicaram alguns dos primeiros trabalhos que associam a composição dos argilominerais ao grau de diagênese. Kübler (1967) padronizou a relação entre largura à meia altura (Full Width at Half Maximum FWHM) da reflexão (001) da illita em difratogramas de raios-X com os limites entre diagênese, anquizona e epizona, denominando-a Índice de Cristalinidade da Illita (ICl). Os valores propostos para estes limites estão listados na tabela 2.

Tabela 2 - Valores dos limites da anquizona, em $\Delta \mathbf{2 \theta}$

\begin{tabular}{llllll}
\hline Zona & Kübler (1967) & Árkai (1991) & $\begin{array}{l}\text { Jaboyedoff } \\
\mathbf{( 2 0 0 1 )}\end{array}$ & et & al. \\
\hline Diagênese & $>0.42$ & $>0.34$ & $>0.42$ \\
\hline Anquizona & $0.42-0.25$ & $0.34-0.25$ & $0.42-0.25$ & \\
\hline Epizona & $<0,25$ & $<0.25$ & $<0.25$ &
\end{tabular}




\subsubsection{Histórico}

Diagênese é o conjunto de processos físico-químicos e biológicos, que ocorrem após a deposição dos sedimentos, pelos quais a assembleia mineral sedimentar original busca atingir equilíbrio geoquímico com o ambiente, reagindo entre si e também com os fluidos intersticiais (Curtis 1977, Burley et al. 1985 in Worden \& Burley 2003).

A diagênese pode ser dividida em três fases (Choquette \& Pray 1970 in Worden \& Burley 2003, Worden \& Burley 2003): diagênese precoce ou eodiagênese, que abrange todos os processos que ocorrem na superfície de deposição ou próximo a ela, e onde a química dos fluidos intersticiais é controlada pelo corpo d'agua que depositou os sedimentos; diagênese de soterramento ou mesodiagênese, que ocorre, durante o soterramento, a partir do ponto no qual a influência dos corpos d'agua superficiais cessa até o limite do metamorfismo de baixo grau; e, por fim, telodiagênese ou diagênese de soerguimento, na qual a rocha sedimentar passa a ser afetada por águas meteóricas, excluindo-se deste grupo os corpos d'agua superficiais.

Outra classificação comumente utilizada separa a diagênese em três estágios: diagênese precoce, anquizona e epizona. A anquizona é tida como o estágio de transição entre a zona de não metamorfismo (diagenética) e de metamorfismo de baixo grau (fácies xisto verde baixo) (Kisch 1983, Frey 1987a in Frey \& Robinson 1998). Kübler (in Kisch 1991) ressalta ainda que, originalmente, os limites entre estas zonas foi baseado no nível de maturação de hidrocarbonetos e em paragêneses mineralógicas características, sendo o limite diagênese-anquizona marcado pelo desaparecimento do gás seco e o limite anquizona-epizona, pelo surgimento de cloritoide. Estes limites são definidos pelos valores de $0,42^{\circ} \Delta 2 \theta$ e $0,25^{\circ} \Delta 2 \theta$ do índice de Kübler, respectivamente.

\subsection{2 Índices de Cristalinidade}

Na década de 1960 foram criados os primeiros índices de cristalinidade da illita, tendo em vista sua grande aplicabilidade na estimativa do grau de diagênese atingido pela rocha, informação de grande interesse para a exploração de petróleo (Abad 2007). O primeiro a verificar a relação das transformações da illita com o avanço da diagênese foi Weaver (1960 in Abad 2007), a partir de observações do formato da reflexão em $10 \AA ̊$. Seu índice, o Índice de Weaver

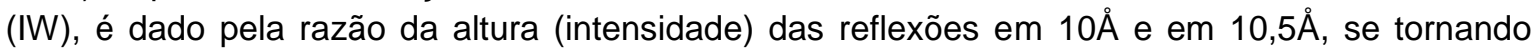
maior com a progressão da diagênese. Kübler (1967) provou que a acurácia do IW era baixa, e propôs outro índice, denominado Índice de Cristalinidade da Illita (ICI), que é a medida em ${ }^{\circ} 2 \theta$ da largura da reflexão 001 da illita à meia altura (Full-Width at Half Maximum - FWHM). Estudos posteriores (ex. Árkai 1991, Arkai et al. 1995, 2003, Battaglia et al. 2004, Bisevac et al. 2010, Drits et al. 1997, Srodon 1984, Srodon et al. 2013, , Warr \& Rice 1994, Jaboyedoff et al. 2001), o renomearam para Índice de Kübler (Kübler Index - KI). Este é amplamente utilizado para determinação das condições de metamorfismo de baixo grau/diagênese, sendo que seu valor diminui com o aumento da intensidade da diagênese até o metamorfismo (Jaboyedoff et al. 2001). Após reuniões promovidas pelo IGCO 294 e a publicação da tese de Frey (1987), foi possível estabelecer padrões de nomenclatura e correlações entre o $\mathrm{ICl}$ e outros critérios, como por exemplo, a refletividade da vitrinita (Nieto 1998).

Em um difratograma, pode haver a sobreposição da reflexão de diversos minerais. 0 exemplo mais comum descrito na literatura (Lanson \& Champion 1991; Lanson \& Besson 1992; Lanson \& Velde 1992; Lanson 1997) enfatiza a região entre 5 e $11^{\circ} 2 \theta(17,6$ a 8,0 $\AA)$, onde ocorre a sobreposição de diferentes picos da esmectita, illita, muscovita, paragonita, interestratificados, entre outros. Como a separação das fases detríticas e diagenéticas durante a preparação não é perfeita, devido ao diminuto tamanho das primeiras, este é um recurso útil para a determinação do valor de ICl com maior segurança. No entanto, Lanson \& Velde (1992) ressaltam que, na presença de uma fase diagenética com alto grau de cristalinidade, esta se torna indistinguível da contribuição detrítica, não sendo possível então determinar sua origem por este método. 
4. MATERIAIS E MÉTODOS

Inicialmente, foi realizada uma revisão bibliográfica das técnicas a serem utilizadas durante o trabalho e da geologia da área de estudo, com enfoque nas rochas do Grupo Bambuí, resultando na Geologia Regional apresentada neste trabalho. Nas regiões onde não há ocorrência confirmada do Gr. Bambuí na literatura, foi gerado um mapa a partir da fotointerpretação de imagens LANDSAT e SRTM, do mapa em escala 1:1.000.000 do Serviço Geológico do Brasil CPRM e de dados de campo.

Os trabalhos de campo ocorreram espaçadamente durante o primeiro ano de trabalho. Foram coletadas 19 amostras em diferentes localidades e níveis estratigráficos da Formação Serra de Santa Helena (tabela 3). Para utilização nas análises, foram selecionadas as porções com menos sinais de alteração de cada amostra. A amostra LS-001, coletada em Guarani de Goiás, não consta no mapa por esta localidade se encontrar muito a norte da área demarcada, e caso fosse plotada, geraria problemas de escala.

Tabela 3 - Litotipos analisados. DRX - Difratometria de Raios-X; PTR - Petrografia; FRX Fluorescência de Raios-X. Observar exceção para as amostras LS-008, cuja zona UTM é $22 S$.

\begin{tabular}{|c|c|c|c|c|c|c|}
\hline \multirow{2}{*}{ Amostra } & \multirow{2}{*}{$\begin{array}{l}\text { Coord. } \\
\text { UTM } \\
\text { Zona 23S }\end{array}$} & \multirow{2}{*}{ Litotipo } & \multirow{2}{*}{ Localidade } & \multicolumn{3}{|c|}{ Análises realizadas } \\
\hline & & & & DRX & PTR & FRX \\
\hline LS - 001 & $\begin{array}{l}349087 / \\
8463751\end{array}$ & $\begin{array}{l}\text { Siltito cinza-claro com } \\
\text { micas detríticas. Pouco } \\
\text { litificado }\end{array}$ & $\begin{array}{l}\text { Guarani de } \\
\text { Goiás-GO }\end{array}$ & OK & OK & OK \\
\hline LS - 002 & $\begin{array}{l}334907 / \\
8331849\end{array}$ & $\begin{array}{l}\text { Arenito muito fino cinza } \\
\text { escuro. Muito litificado }\end{array}$ & $\begin{array}{l}\text { Serra de S. } \\
\text { Domingos- } \\
\text { MG }\end{array}$ & OK & OK & OK \\
\hline LS - 003 & $\begin{array}{l}334907 / \\
8331849\end{array}$ & $\begin{array}{l}\text { Arenito muito fino cinza } \\
\text { escuro. Muito litificado }\end{array}$ & $\begin{array}{l}\text { Serra de S. } \\
\text { Domingos- } \\
\text { MG }\end{array}$ & OK & OK & OK \\
\hline LS - 004 & $\begin{array}{l}334907 / \\
8331849\end{array}$ & $\begin{array}{l}\text { Arenito muito fino cinza } \\
\text { escuro. Muito litificado }\end{array}$ & $\begin{array}{l}\text { Serra de S. } \\
\text { Domingos- } \\
\text { MG }\end{array}$ & OK & OK & OK \\
\hline LS - 005 & $\begin{array}{l}334907 / \\
8331849\end{array}$ & $\begin{array}{l}\text { Siltito verde-escuro } \\
\text { moderadamente } \\
\text { alterado. }\end{array}$ & $\begin{array}{l}\text { Serra de S. } \\
\text { Domingos- } \\
\text { MG }\end{array}$ & OK & OK & OK \\
\hline $14-I I-56$ & $\begin{array}{l}338626 / \\
8329698\end{array}$ & $\begin{array}{l}\text { Arenito muito fino cinza } \\
\text { escuro. Muito litificado }\end{array}$ & $\begin{array}{l}\text { Serra de S. } \\
\text { Domingos- } \\
\text { MG }\end{array}$ & OK & OK & OK \\
\hline LS - 006 & $\begin{array}{l}200466 / \\
8334922\end{array}$ & $\begin{array}{l}\text { Arenito muito fino cinza } \\
\text { claro. Muito litificado }\end{array}$ & $\begin{array}{l}\text { Água Fria- } \\
\text { GO }\end{array}$ & OK & OK & OK \\
\hline LS - 007 & $\begin{array}{l}192398 / \\
8325875\end{array}$ & $\begin{array}{l}\text { Arenito muito fino cinza } \\
\text { claro. Muito litificado }\end{array}$ & $\begin{array}{l}\text { Água Fria- } \\
\text { GO }\end{array}$ & OK & OK & OK \\
\hline 11-I-68 & $\begin{array}{l}275052 / \\
8294935\end{array}$ & $\begin{array}{l}\text { Arenito muito fino cinza } \\
\text { claro, alterado nas } \\
\text { bordas. }\end{array}$ & Formosa-GO & OK & OK & OK \\
\hline 11-II-76 & $\begin{array}{l}270221 / \\
8297931\end{array}$ & $\begin{array}{ll}\text { Arenito fino silicificado } \\
\text { cinza claro. Pouco } \\
\text { denso. } & \\
\end{array}$ & Formosa-GO & OK & & \\
\hline 11-II-78 & $\begin{array}{l}270740 / \\
8297928 \\
\end{array}$ & $\begin{array}{l}\text { Arenito muito fino cinza } \\
\text { escuro. Muito litificado. }\end{array}$ & Formosa-GO & OK & OK & OK \\
\hline $11-|| \mid-84$ & $\begin{array}{l}282129 / \\
8298042\end{array}$ & $\begin{array}{l}\text { Siltito cinza escuro } \\
\text { laminado }\end{array}$ & Formosa-GO & OK & OK & OK \\
\hline 12-IV-78 & $\begin{array}{l}264291 / \\
8312999\end{array}$ & $\begin{array}{l}\text { Arenito muito fino de } \\
\text { cor verde-amarelada. }\end{array}$ & Formosa-GO & OK & OK & \\
\hline $13-V-1$ & $\begin{array}{l}260900 / \\
8331369 \\
\end{array}$ & $\begin{array}{l}\text { Arenito fino } \\
\text { azulado maciço. }\end{array}$ & Formosa-GO & OK & OK & OK \\
\hline LFDF006 & $\begin{array}{l}181773 / \\
8283864\end{array}$ & $\begin{array}{l}\text { Arenito muito fino cinza } \\
\text { esverdeado }\end{array}$ & $\begin{array}{ll}\text { Norte } & \text { do } \\
\text { Distrito } & \\
\text { Federal } & \end{array}$ & OK & OK & OK \\
\hline
\end{tabular}




\begin{tabular}{llllllll} 
LFDF006.2 & $\begin{array}{l}181773 / \\
8283864\end{array}$ & \multicolumn{2}{l}{$\begin{array}{l}\text { Arenito muito fino cinza } \\
\text { esverdeado }\end{array}$} & $\begin{array}{l}\text { Norte } \\
\text { Distrito } \\
\text { Federal }\end{array}$ & OK & OK & \\
\hline LS-008a & $\begin{array}{l}790960 / \\
8321502\end{array}$ & $\begin{array}{l}\text { Pelito maciço } \\
\text { acinzentado }\end{array}$ & bege- & $\begin{array}{l}\text { Padre } \\
\text { Bernardo-GO }\end{array}$ & OK & OK & OK \\
\hline LS-008b & $\begin{array}{l}790960 / \\
8321502\end{array}$ & $\begin{array}{l}\text { Pelito maciço } \\
\text { amarelado }\end{array}$ & bege- & $\begin{array}{l}\text { Padre } \\
\text { Bernardo-GO }\end{array}$ & OK & OK & \\
& 8 & & & &
\end{tabular}

\subsection{Petrografia}

As lâminas petrográficas foram confeccionadas no Laboratório de Laminação do Instituto de Geociências - IG-UnB. Para cada amostra foi determinada a melhor seção para confeccionar a lâmina, preferencialmente perpendicular ao plano de acamamento, visando a descrição da mineralogia e estruturas deposicionais/pós-deposicionais. A estimativa de porcentagem dos constituintes da rocha foi realizada tomando-se como referência a escala presente na lente ocular. Esta contagem foi realizada em diferentes pontos da lâmina, e a partir destas foi feita a média das porcentagens.

A análise das lâminas foi realizada em um microscópio modelo ZEISS Axiolmager.A2m, equipado com uma câmera AxioCamICc 3, para obtenção de fotomicrografias.

\subsection{Difratometria de Raios-X}

As análises por Difratometria de Raios- $X$ foram realizadas no difratômetro Rigaku Ultima IV do Laboratório de Difratometria de Raios-X (LARIX-UnB), operando com tubo de cobre e filtro de níquel, sob voltagem de $35 \mathrm{kV}$ e $15 \mathrm{~mA}$, à velocidade de varredura de $5 \% \mathrm{~min}$. O intervalo de varredura foi de 2 a $80^{\circ}$ para a amostra total (amostra pulverizada em grau de ágata e compactada a seco em lâmina de vidro com cavidade retangular) e de 2 a $40^{\circ}$ para a fração argila. Para separação da fração argila, foram dispersos $2,5 \mathrm{~g}$ de material pulverizado em $50 \mathrm{~mL}$ de água destilada. Essa mistura foi centrifugada em um primeiro ciclo, a 750rpm por 7 minutos, separado $o$ sobrenadante, e então novamente centrifugada em um segundo ciclo, a 3000rpm por 30 minutos, para decantação da fração argila. Caso houvesse sobrenadante após o segundo ciclo, a mistura passaria por um terceiro ciclo a 10000rpm por 10 minutos, para decantação da fração $<0,2 \mu \mathrm{m}$. $O$ material decantado foi então espalhado sobre uma lâmina de vidro usando a técnica do esfregaço, e seco ao ar. Posteriormente essas lâminas foram solvatadas com etileno-glicol e aquecidas a $490^{\circ} \mathrm{C}$ por 4 horas em mufla N480D da Fornos Magnus.

Neste trabalho foram testados dois métodos de desagregação em oito amostras, o moinho micronizador McCrone (figura 2) e o morteiro (figura 3) (como sugerido por Kisch 1991, Árkai \& Lelkes-Felvári 1993 e Süssenberger et al. 2014), tendo em vista a melhor separação dos componentes detríticos e diagenéticos. Para o moinho McCrone, foram realizados dois ciclos de 10 minutos para as amostras mais resistentes, e dois ciclos de 5 minutos para as amostras menos resistentes. Para o morteiro, foram utilizados $2,5 \mathrm{~g}$ de material triturado até o tamanho de grânulo, "desagregado" em ciclos de aproximadamente 1 minuto. Para ambos os métodos, ao final de cada ciclo o material fino desagregado foi separado, evitando assim a pulverização excessiva.

A interpretação dos difratogramas e a medição do $\mathrm{FWHM}$, em ${ }^{\circ} \Delta 2 \theta$, foram realizadas com o auxílio do programa JADE 9.0 para WINDOWS, utilizando o banco de dados PC-PDF (Powder Diffraction File - PDF para PC) produzido pelo ICDD (International Center for Diffraction Data). Para este trabalho, foi utilizada a reflexão 001 da illita tanto no difratograma da lâmina orientada seca ao ar quanto na solvatada com etileno-glicol, bem como os valores de $0.420^{\circ} \Delta 2 \theta$ CuKa e $0.250^{\circ} \Delta 2 \theta$ CuKa como limite inferior e superior da anquizona, respectivamente (Kübler 1967).

Para realização da decomposição foi utilizado o software DECOMPXR, como descrito em Lanson (1997). Este programa, a partir da comparação dos difratogramas com funções matemáticas (gaussiana), gera novas reflexões cuja soma se aproxima ao máximo daquela do difratograma original. Neste programa também foram medidos, em ${ }^{\circ} \Delta 2 \theta$, os valores de FWHM da illita. 


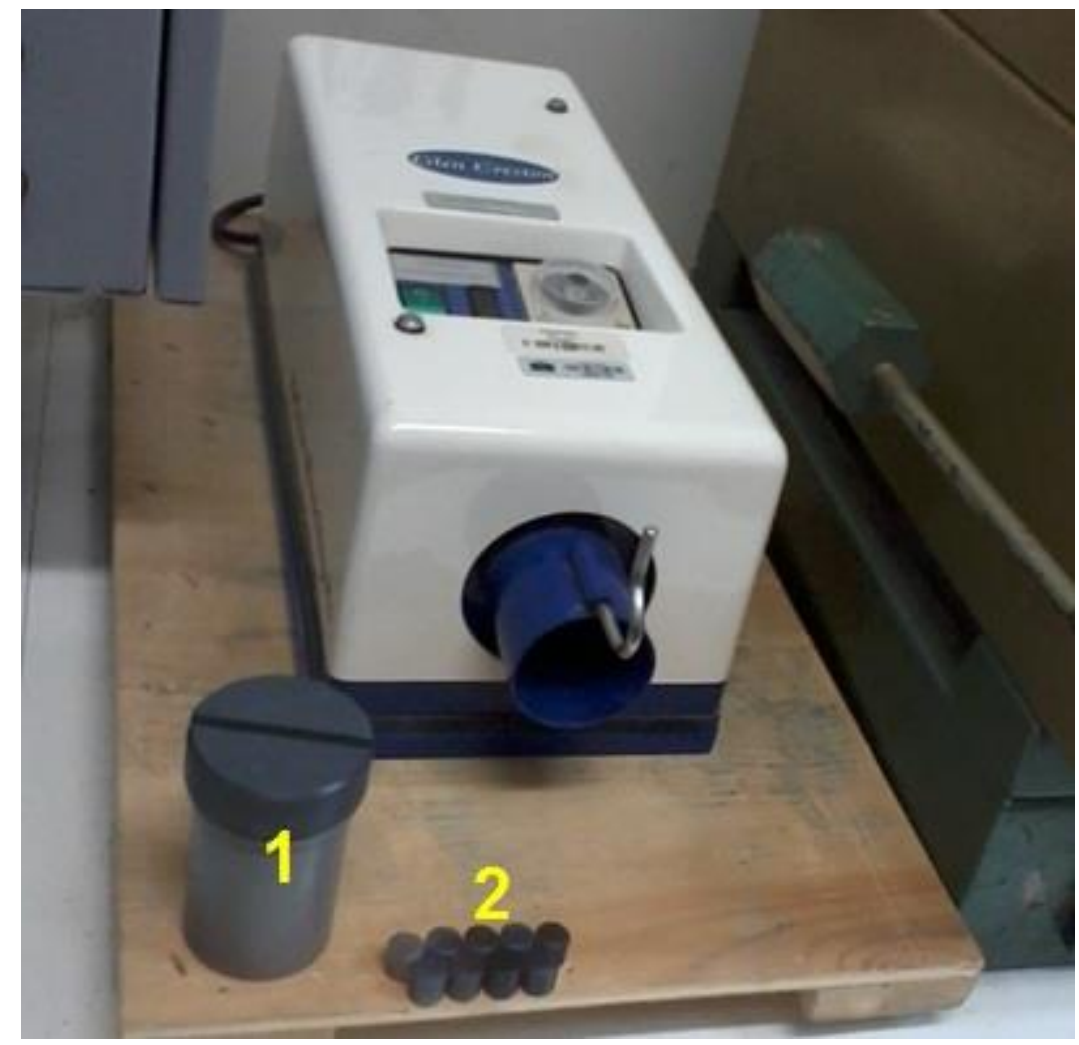

Figura 2 - Moinho Micronizador McCrone. Observar o recipiente para colocação da amostra (1) e as peças de ágata utilizadas na moagem (2).

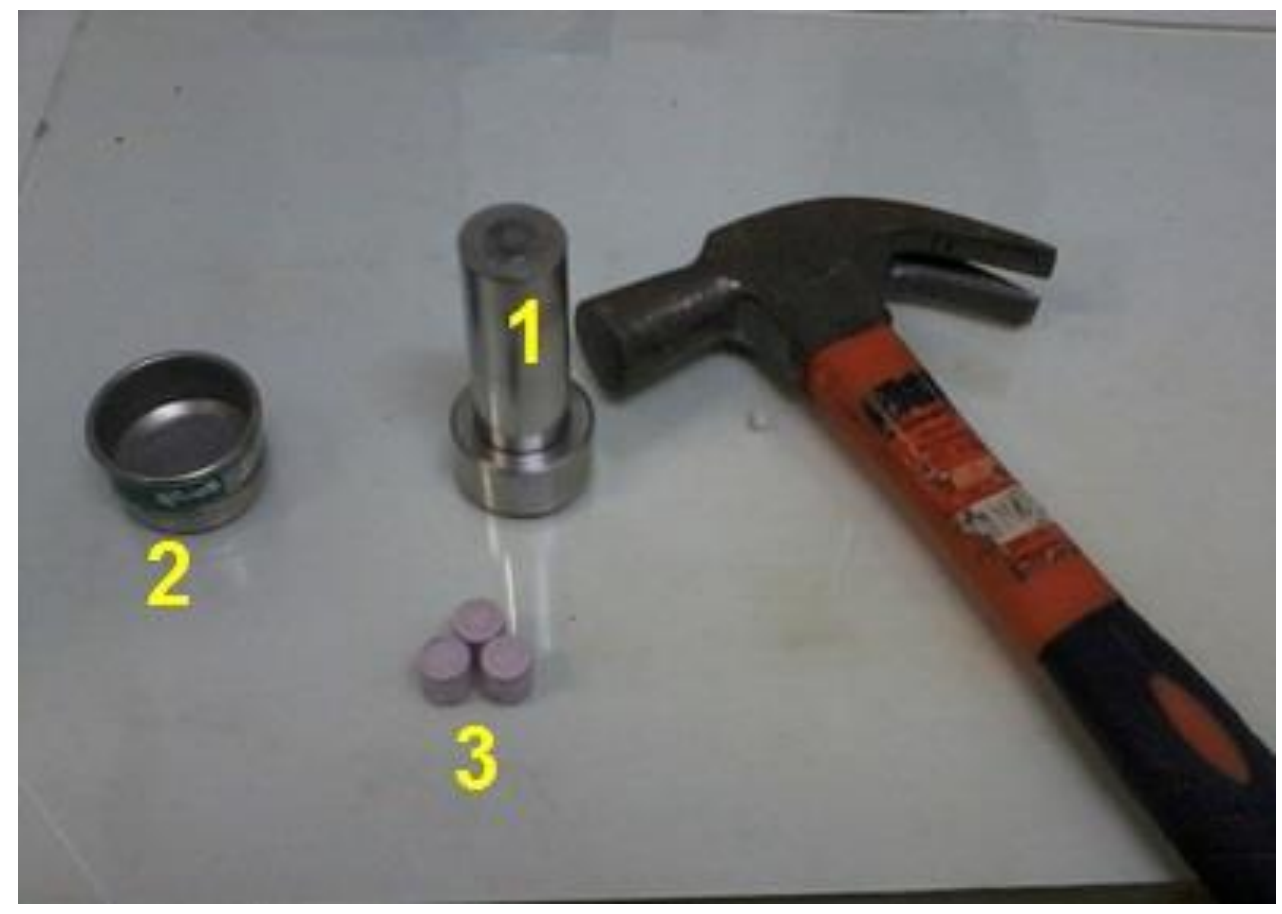

Figura 3 - Morteiro (1), peneira (2) e peças de moagem de coríndon (3).

\subsection{Fluorescência de Raios-X}

As análises geoquímicas foram realizadas no Laboratório de Geocronologia da Universidade de Brasília, em Espectrômetro de fluorescência de raio $X$ dispersivo de comprimento de onda com tubo superior ZSX Primus II. Foram realizados procedimentos para determinação do 
valor de "Perda ao Fogo" e a confecção das pastilhas de material prensado para análise de Fluorescência de Raios-X, obtendo-se a concentração de 10 elementos maiores.

Para a perda ao fogo, $2,1 \mathrm{~g}$ da amostra pulverizada foi levada à estufa a $70^{\circ} \mathrm{C}$ por 12 horas. Os cadinhos foram tarados em mufla, por 1 hora à $1000^{\circ} \mathrm{C}$, pesados, e o valor obtido anotado na planilha "Análise de Perda ao Fogo". As amostras foram então levadas à mufla, a $1000^{\circ} \mathrm{C}$, por 2 horas, sendo necessário abri-la periodicamente para que haja escape dos elementos voláteis que impediriam a calcinação completa. Os cadinhos foram então colocados no dessecador até atingirem a temperatura ambiente, pesados e o valor do peso total (cadinho tarado + amostra após aquecimento a $1000^{\circ} \mathrm{C}$ ) anotado na planilha. Por fim, foi calculada a porcentagem de Perda ao Fogo diretamente no Excel.

Para a confecção do disco de amostra fundida foram misturados $0,9 \mathrm{~g}$ de amostra, $9,0 \mathrm{~g}$ de Tetraborato de Lítio $\left(\mathrm{Li}_{2} \mathrm{~B}_{4} \mathrm{O}_{7}\right)$ e, posteriormente, três espátulas pequenas de nitrato de amônio $\left(\mathrm{NH}_{4} \mathrm{NO}_{3}\right)$. A mistura foi homogeneizada em um cadinho de platina, onde foram adicionadas duas gotas de solução de Brometo de Lítio ( $\mathrm{LiBr}$ ) $50 \% \mathrm{~m} / \mathrm{v}$, e levada para a fusora.

\section{RESULTADOS}

São apresentados a seguir os resultados da petrografia, dos métodos de desagregação das amostras, e das análises por difratometria e fluorescência de Raios- $X$, bem como dos métodos de desagregação das amostras. Para informação de minerais em tabelas e figuras foram utilizadas as siglas propostas por Krets (1983) (tabela 4).

Tabela 4 - Siglas padrão dos minerais citados neste trabalho, segundo Krets (1983)

\begin{tabular}{llll} 
Sigla & Mineral & Sigla & Mineral \\
\hline$C h l$ & Clorita & $O p$ & Opacos \\
\hline$I I I$ & Illita & $P l$ & Plagioclásio \\
\hline$K f s$ & Feldspato potássico & $Q t z$ & Quartzo \\
\hline$L$ & Fragmento lítico & $V r m$ & Vermiculita \\
\hline$M s$ & Muscovita & $Z r n$ & Zircão
\end{tabular}

\subsection{Petrografia}

Na região da Serra de São Domingos, em Formosa-GO e no norte do Distrito Federal foi possível reconhecer e individualizar, em campo e por fotointerpretação, os afloramentos da Formação Serra de Santa Helena. Estes se destacam na paisagem como cristas alongadas e baixas, de topo arredondado, contrastando com o relevo rebaixado correspondente aos siltitos e às cristas carbonáticas das formações Sete Lagoas e Lagoa do Jacaré. Em Água Fria-GO também é possível reconhecer essas cristas, porém sua relação com as unidades carbonáticas próximas é incerta. Em Padre Bernardo-GO não foi possível diferenciar unidades, e a feição característica dos arenitos da Formação Serra de Santa Helena não é observada.

Foram observadas, nos afloramentos, estruturas deposicionais como marcas onduladas (figura 4) e hummocky (figura 5) e também variação na granulometria das rochas, com intercalações métricas entre as fácies psamíticas e pelíticas (figura 6). Quando frescas essas rochas apresentam coloração azul escura a cinza azulada, que se torna cinza esverdeada até bege amarelada com a progressão do intemperismo. Mesmo levemente intemperizada, apresenta alta resistência mecânica. 


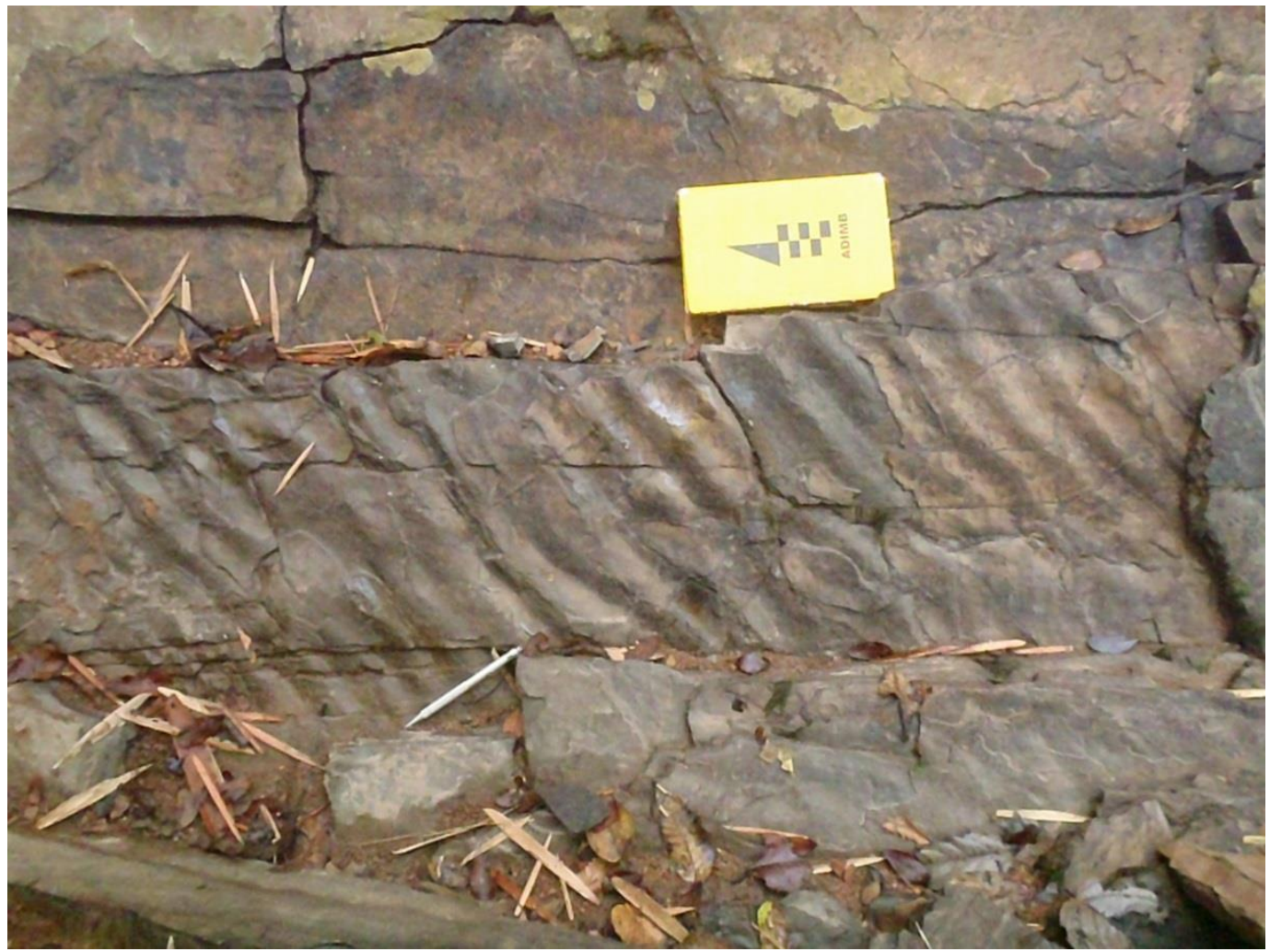

Figura 4 - Arenito muito fino com marcas onduladas. Formação Serra de Santa Helena próximo à Serra de São Domingos-MG, ponto 14-II-56.

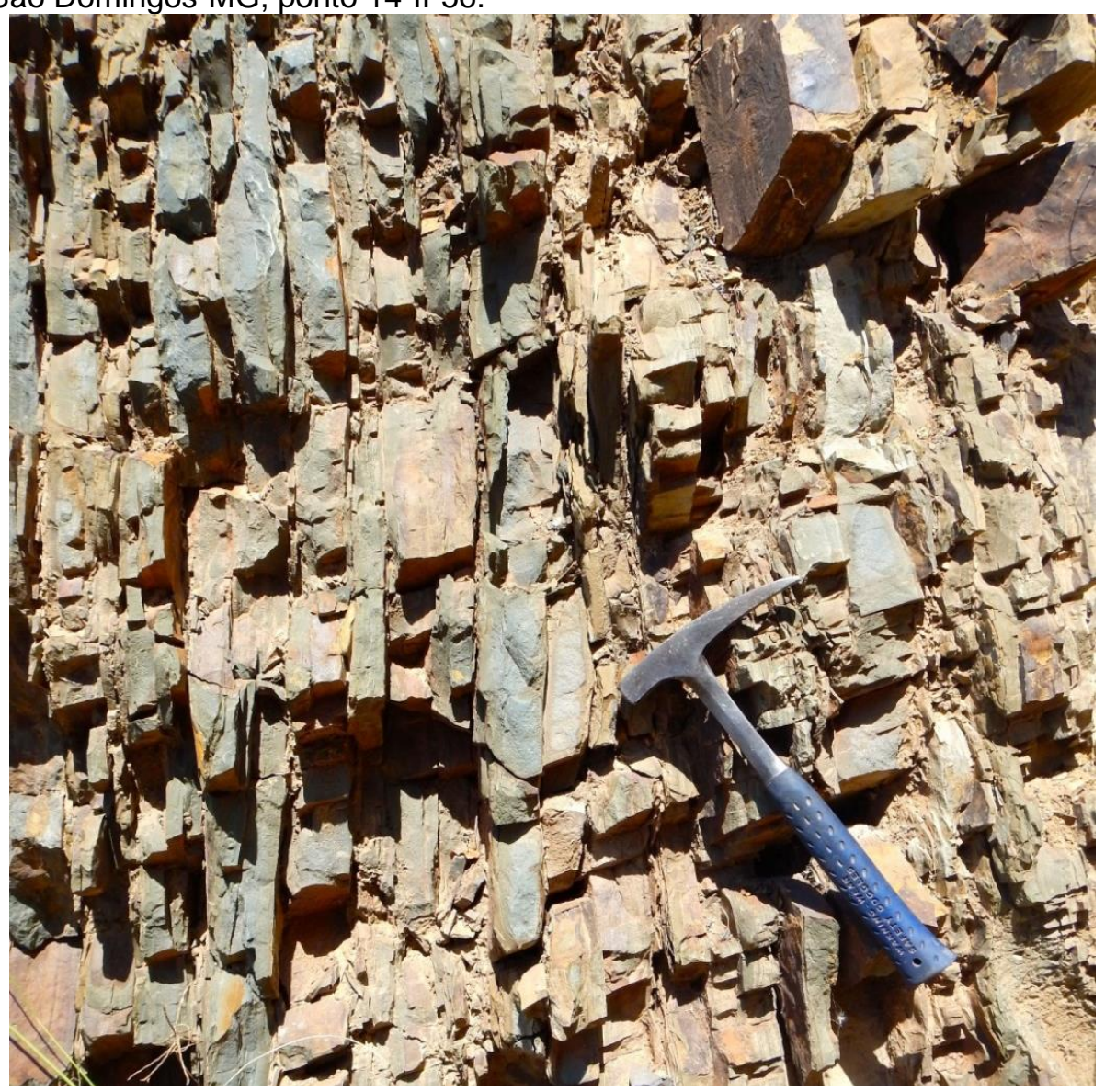

Figura 5 - Arenito muito fino. Observar o formato lenticular de algumas camadas, caracterizando estruturas tipo hummocky. Fm. Serra de Santa Helena próximo à Serra de São Domingos-MG, ponto LS-004. 


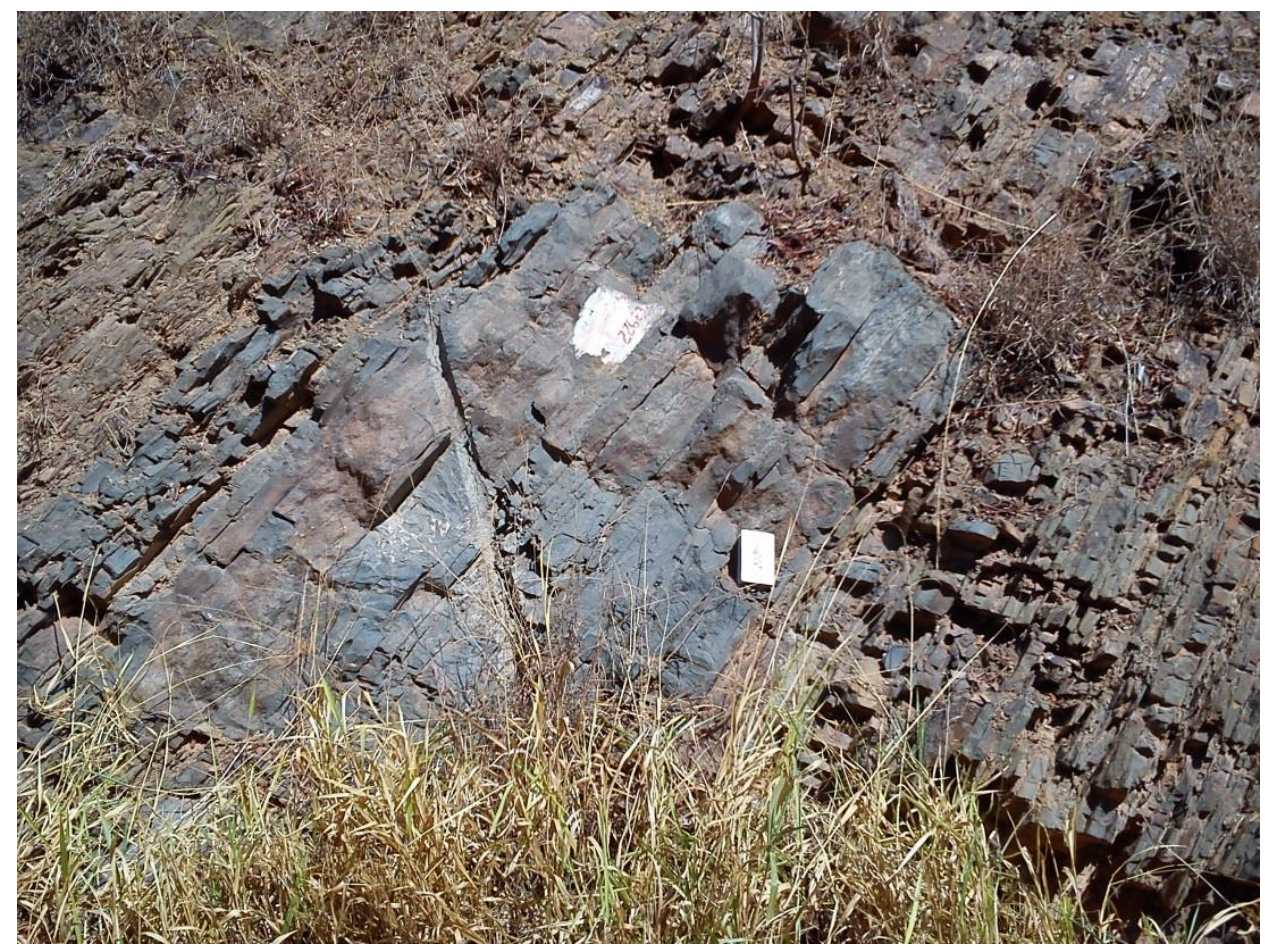

Figura 6 - Camadas mais espessas, no centro da foto, correspondem aos arenitos muito finos, enquanto as mais finas correspondem a ritmitos compostos por siltitos e arenitos muito finos. Fm. Serra de Santa Helena próximo à Serra de São Domingos-MG, ponto LS-005.

Foram identificados, por petrografia, os seguintes minerais: Quartzo, muscovita, clorita, plagioclásio, biotita e feldspato potássico (microclínio) como componentes do arcabouço, zircão e turmalina como minerais acessórios e pirita e hematita como minerais opacos (tabela 5). Para efeito de análise de proveniência e ambiente tectônico, será considerada toda a matriz como pseudomatriz, proveniente da compactação diagenética de grãos lábeis.

Tabela 5 - Composição mineral identificada por petrografia

\begin{tabular}{|c|c|c|c|c|c|c|c|c|c|c|}
\hline & & \multicolumn{9}{|c|}{ Minerais } \\
\hline Amostras & Qtz & PI & Ms & ChI & $\mathrm{Bt}$ & Kfs & Op & $\mathbf{L}$ & Zrn & Mtx \\
\hline LS-001 & & & & & & & & & & $90-50$ \\
\hline LS-002 & 50 & 7 & 4 & 7 & - & - & 6 & 5 & - & 22 \\
\hline LS-003 & 45 & 4 & 15 & 10 & - & - & - & - & 1 & 25 \\
\hline LS-004 & 53 & 6 & 7 & 7 & - & - & 3 & - & - & 24 \\
\hline LS-005 & & & & & & & & & & \\
\hline 14-II-56 & 42 & 7 & 7 & 7 & - & - & 1 & - & - & 36 \\
\hline LS-006 & 45 & 5 & 4 & 3 & - & 4 & 1 & - & - & 38 \\
\hline LS-007 & 40 & 7 & 8 & 6 & - & 2 & 7 & - & - & 30 \\
\hline $11-I-68$ & 50 & 5 & 3 & 5 & 2 & - & 3 & - & - & 32 \\
\hline 11-II-78 & 50 & 9 & 5 & 4 & - & 3 & 1 & - & - & 28 \\
\hline 11-III-84 & 32 & 3 & 15 & 10 & - & - & 10 & - & - & 30 \\
\hline 12-IV-78 & 40 & 12 & 2 & 3 & - & 2 & 2 & - & - & 39 \\
\hline $13-V-1$ & 33 & 4 & 3 & 1 & 1 & 5 & 8 & - & - & 44 \\
\hline LFDF006 & 30 & 4 & 4 & 4 & 6 & 7 & 6 & 4 & - & 35 \\
\hline LFDF006.2 & 26 & 5 & 8 & 3 & 8 & 11 & 5 & 4 & - & 30 \\
\hline LS-008a & & & & & - & & & & & \\
\hline LS-008b & & & & & - & & & & & \\
\hline
\end{tabular}

As rochas analisadas são arenitos muito finos, geralmente com muita matriz (em média 30\%), e siltitos. De acordo com a classificação de Pettijohn et al. (1972), são grauvacas líticas (figura 7). No diagrama de Dickinson et al. (1983) (figura 8), os pontos plotam no campo Orógeno Reciclado.

O principal componente do arcabouço é o quartzo, geralmente monocristalino com extinção reta, raramente com extinção ondulante, subanguloso a subarredondado. Em algumas lâminas foram observados grãos de quartzo arredondados (figura 9) e policristalinos, em 
proporção igual ou menor a $1 \%$ da rocha. O feldspato predominante é o plagioclásio, exibindo macla polissintética (figura 10), porém em algumas amostras ocorre feldspato potássico, discernível do quartzo pela macla xadrez (microclínio) (figura 11) ou pela alteração parcial/total para argilominerais (figura 12), o que faz com que seja incluído na matriz. Muscovita detrítica ocorre como palhetas, orientadas segundo os planos de acamamento, muitas vezes deformadas por compactação dos sedimentos (figura 13). Clorita detrítica ocorre como palhetas alongadas ou como grãos, com cor variando de marrom-esverdeado a verde-claro em N// (figura 14), podendo ser a alteração de minerais ferromagnesianos variados como biotita e anfibólio. Localmente observa-se biotita completamente preservada (figura 15), que exibe cor de interferência de alta ordem em contraste com o azul-acinzentado da clorita. Nas rochas com grau de alteração moderado predomina a variedade de clorita com pleocroísmo de verde a verde claro ou incolor, geralmente associado à espécie magnesiana. Illita e clorita diagenéticas ocorrem na matriz, conferindo a esta um aspecto esverdeado. Minerais acessórios observados foram grãos de zircão e muito raramente turmalina. Os minerais opacos são principalmente pirita euédrica a subédrica (figura 16) e substituições de pirita, feldspatos e filossilicatos por óxidos de ferro.

Nas rochas com sinais de alteração intempérica, observam-se cristais de vermiculita (figura 17), com pleocroísmo de amarelo claro a castanho escuro e cor de interferência que varia desde amarelo pálido de baixa ordem até tons de vermelho e azul de mais alta ordem. São possivelmente derivados da alteração de biotita e clorita, esta última tanto detrítica quanto diagenética. $O$ hábito do cristal mostrado na figura 18, juntamente com a direção de crescimento das palhetas de vermiculita, indicam que possivelmente anfibólio tenha sido um componente da rocha-fonte.

O cimento é geralmente silicoso ou ferruginoso. No primeiro caso se apresenta como pequenos sobrecrescimentos nos grãos de quartzo, totalizando $1 \%$ ou menos da rocha (figura 19). No segundo caso, o cimento tem origem na alteração intempérica de minerais ferromagnesianos, substituindo boa parte da matriz argilosa e alguns grãos de minerais instáveis, como feldspatos e pirita (figura 20).

Nos pelitos, é possível identificar estruturas pós-deposicionais, como micro escorregamentos e deformação sin-sedimentar (figura 21). Tais estruturas podem indicar deposição em ambiente instável, como taludes. As estruturas identificáveis nas grauvacas são estratificações cruzadas (figura 22), acamamento gradacional (figura 23) e laminação planoparalela, muitas vezes identificável pela variação na quantidade de matriz. 


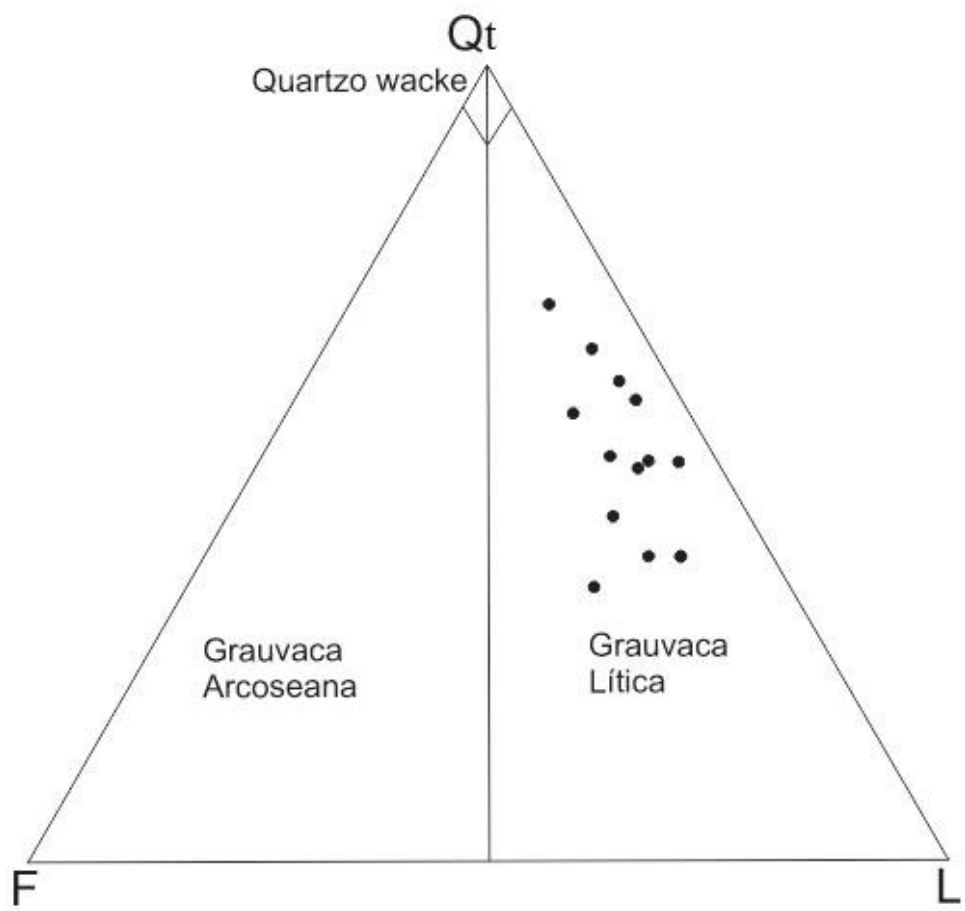

Figura 7 - Classificação petrográfica de Pettijohn et al. (1972). As amostras são classificadas como grauvacas líticas. Qt - Quartzo total; F - Feldspatos; L - Fragmentos líticos.

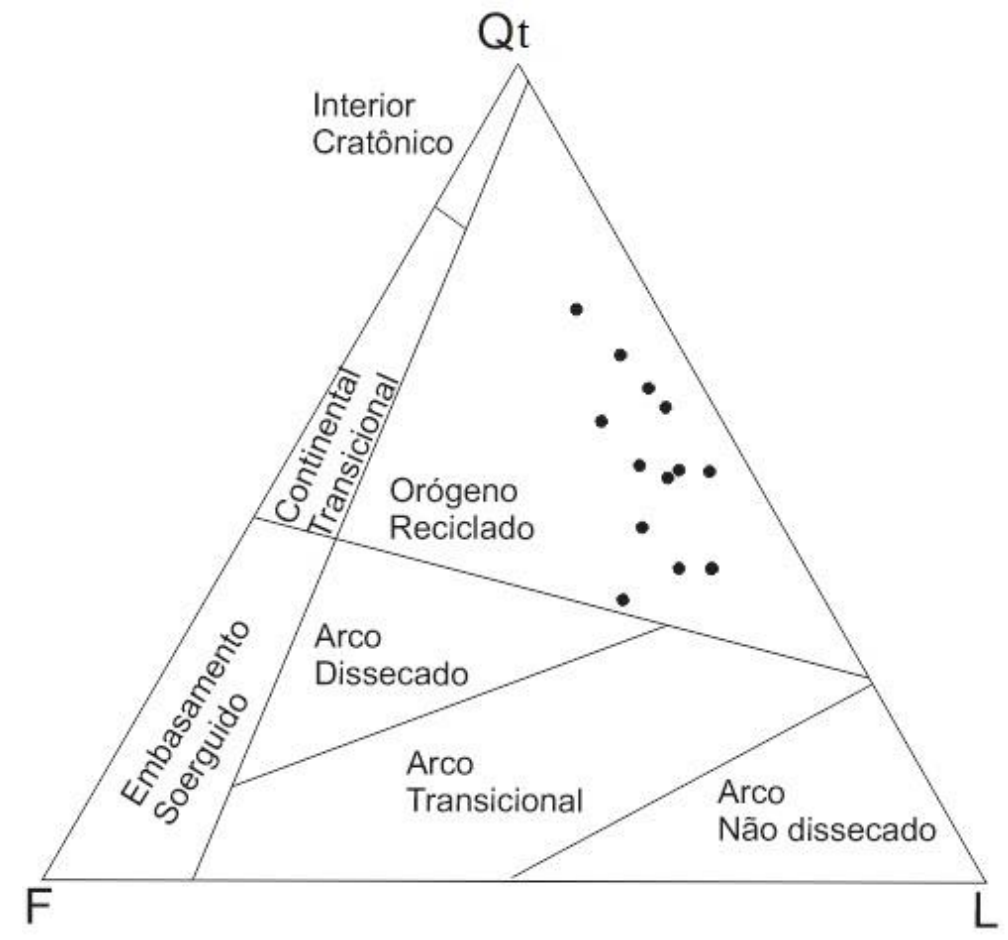

Figura 8 - Diagrama de Dickinson et al. (1983) mostrando a proveniência dos sedimentos que compõem os arenitos de acordo com a composição mineralógica. Qt - Quartzo total; F Feldspatos; L - Fragmentos líticos. 


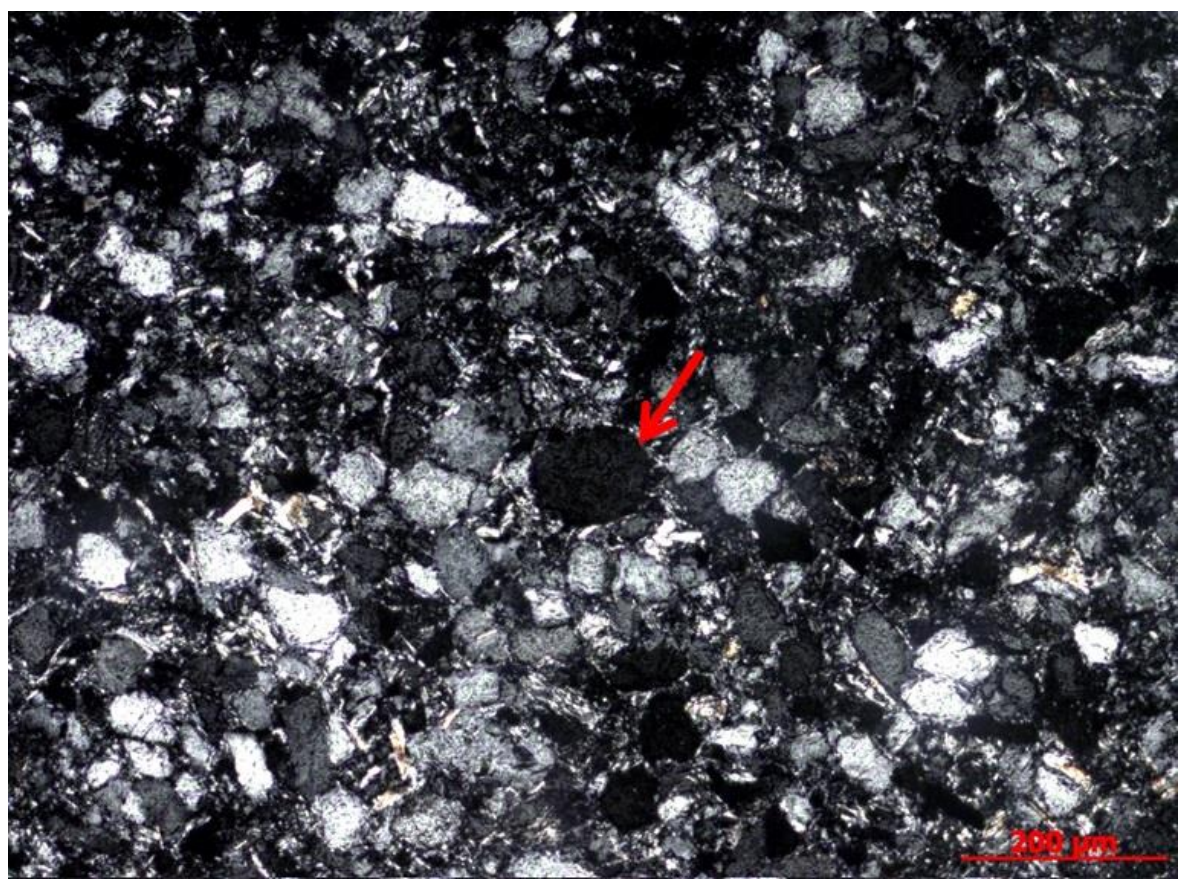

Em sentido anti-horário:

Figura 9 - No centro da foto, grão de quartzo arredondado (Nicóis cruzados, Ponto 13-V-1).

Figura 10 - No centro da foto, grão de plagioclásio exibindo macla polissintética (lei da albita) (Nicóis cruzados, ponto LS-004). Qtz - Quartzo; $\mathrm{PI}$ - Plagioclásio.

Figura 11 - No centro da foto, grão de microclínio límpido, exibindo característica macla "tartan" (Nicóis cruzados, ponto LS-006). Qtz - Quartzo; Kfs - Feldspato potássico; Ms - Muscovita.
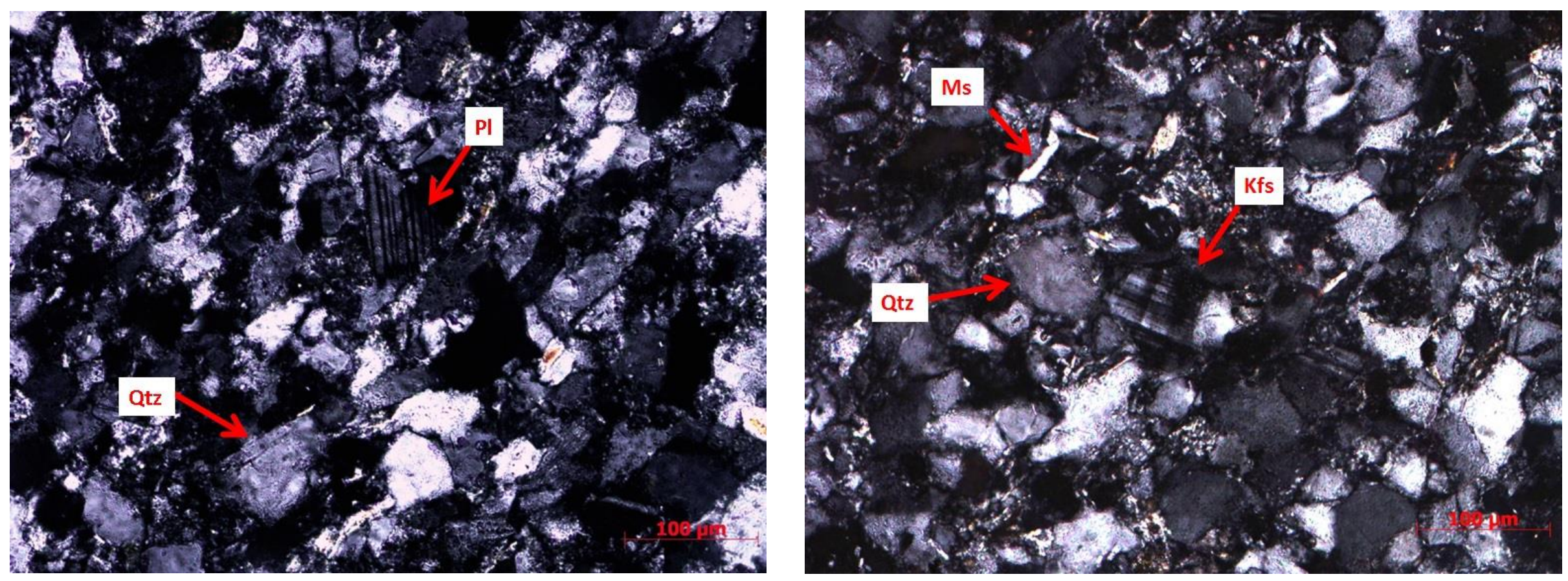


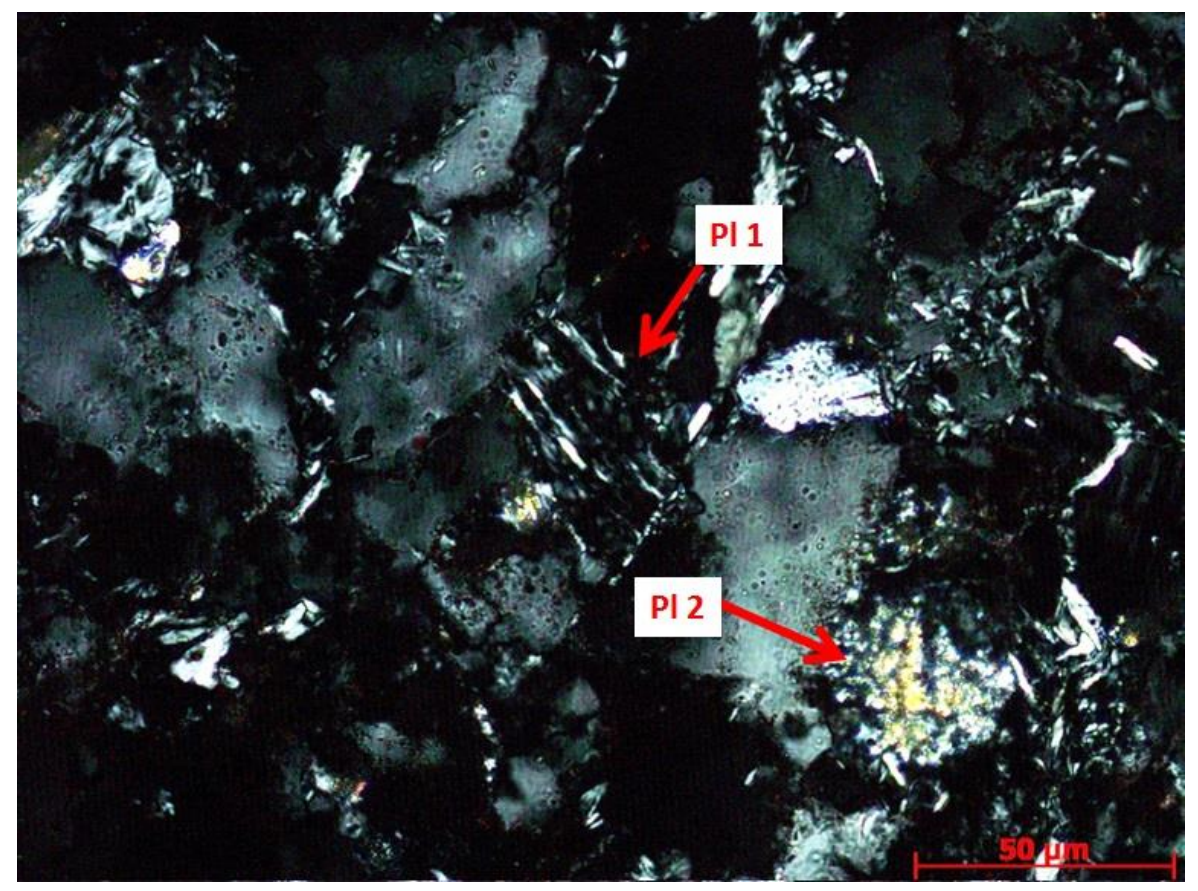

Em sentido anti-horário:

Figura 12 - Grão de feldspato parcialmente alterado para illita (PI 1), no qual as palhetas de illita se desenvolveram nos planos de clivagem. Há também um grão de feldspato completamente alterado (PI 2). PI - Plagioclásio.

Figura 13 - Palheta de muscovita detrítica (indicada pela seta) deformada por compactação (Nicóis cruzados, ponto 12-IV-78).

Figura 14 - No centro da foto, palheta de clorita detrítica indicada pela seta (Nicóis paralelos, ponto LS-003).
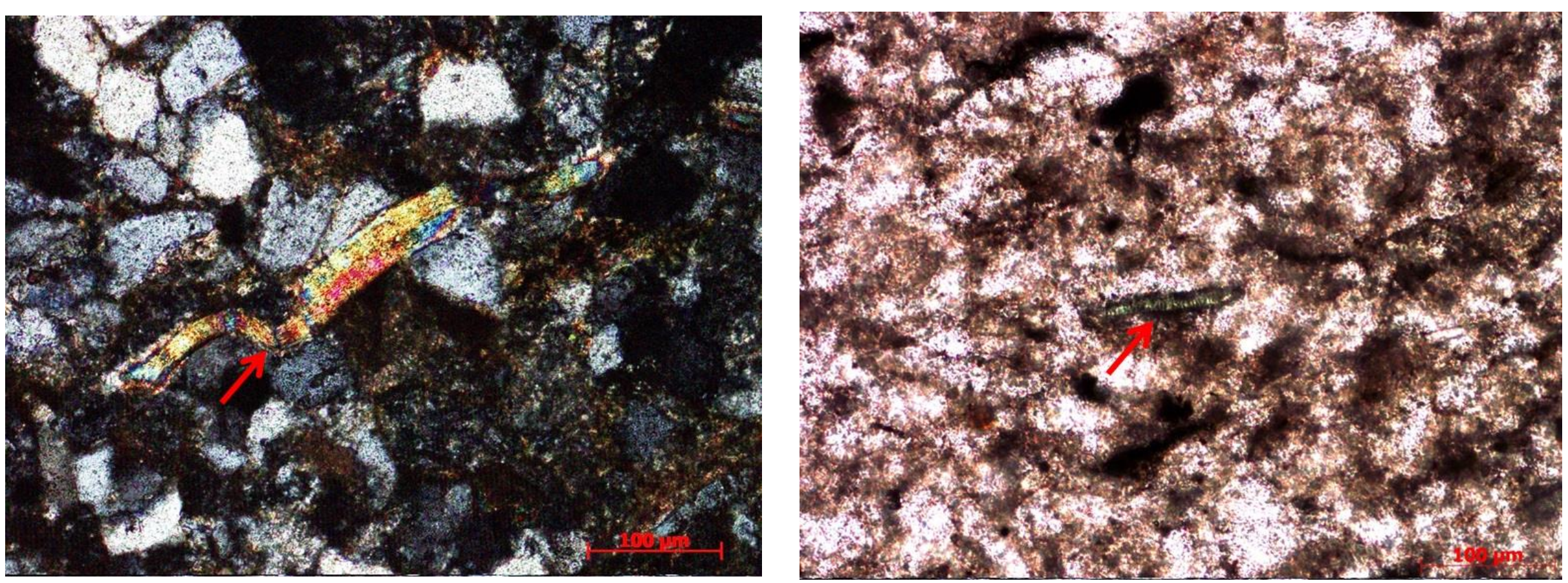


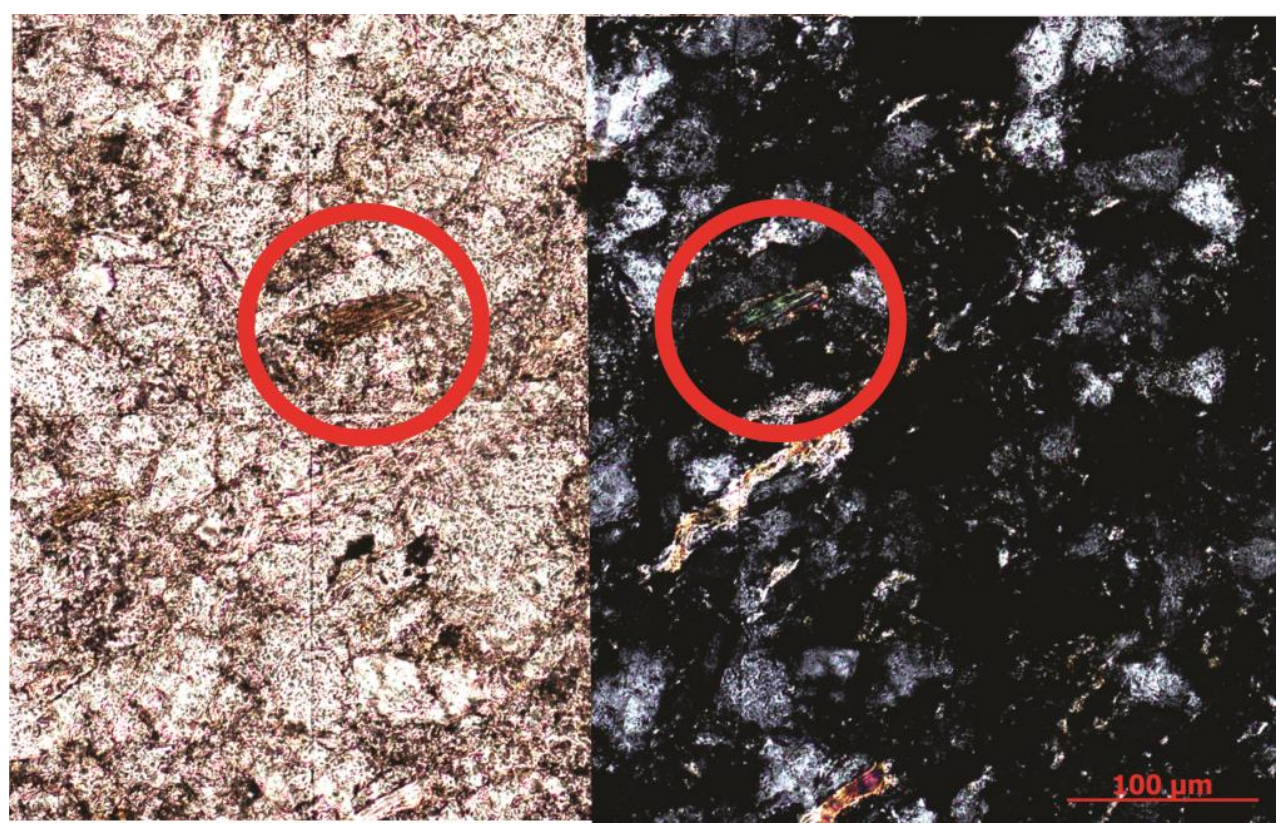

Em sentido anti-horário:

Figura 15 - Destacada nas duas imagens, palheta de biotita detrítica vista sob nicóis paralelos (esquerda) e cruzados (direita) (ponto 12-IV-78).

Figura 16 - Cristais euédricos de pirita, exibindo coloração amarelo clara (destacados pelas setas) (Luz refletida sob nicóis paralelos, ponto LS002).

Figura 17 - Palhetas de vermiculita vistas em nicóis paralelos (esquerda) e cruzados (direita), indicadas pelas setas (ponto LS-008a).
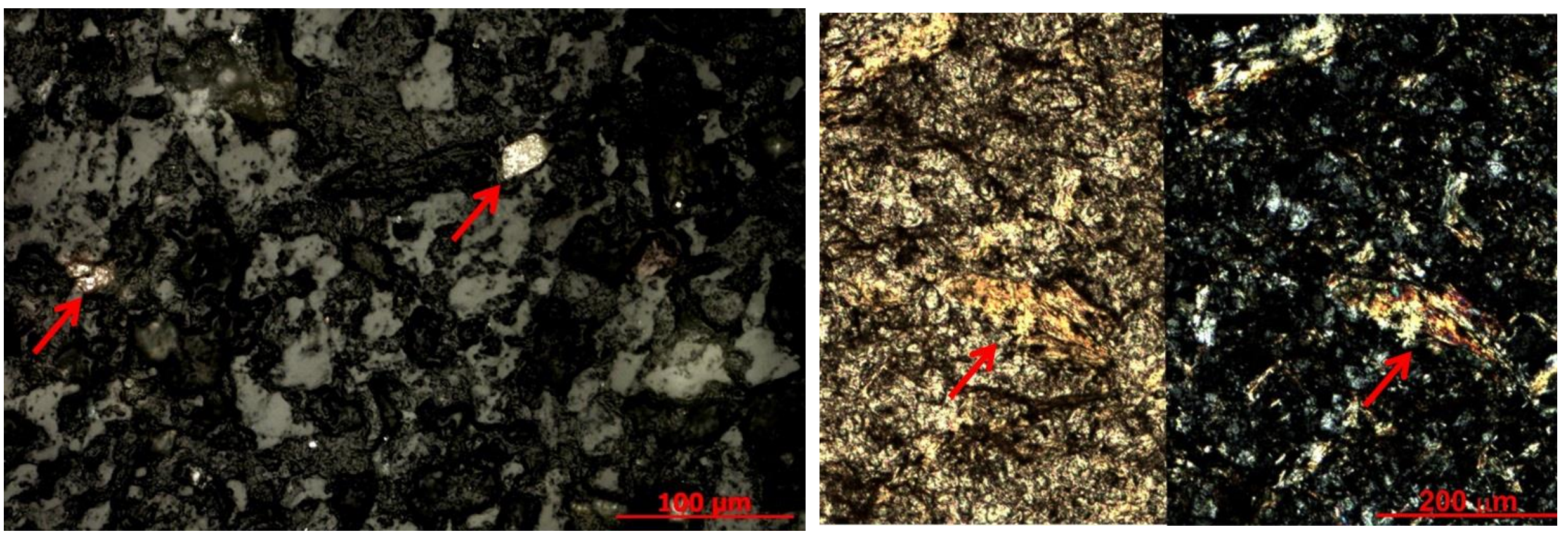


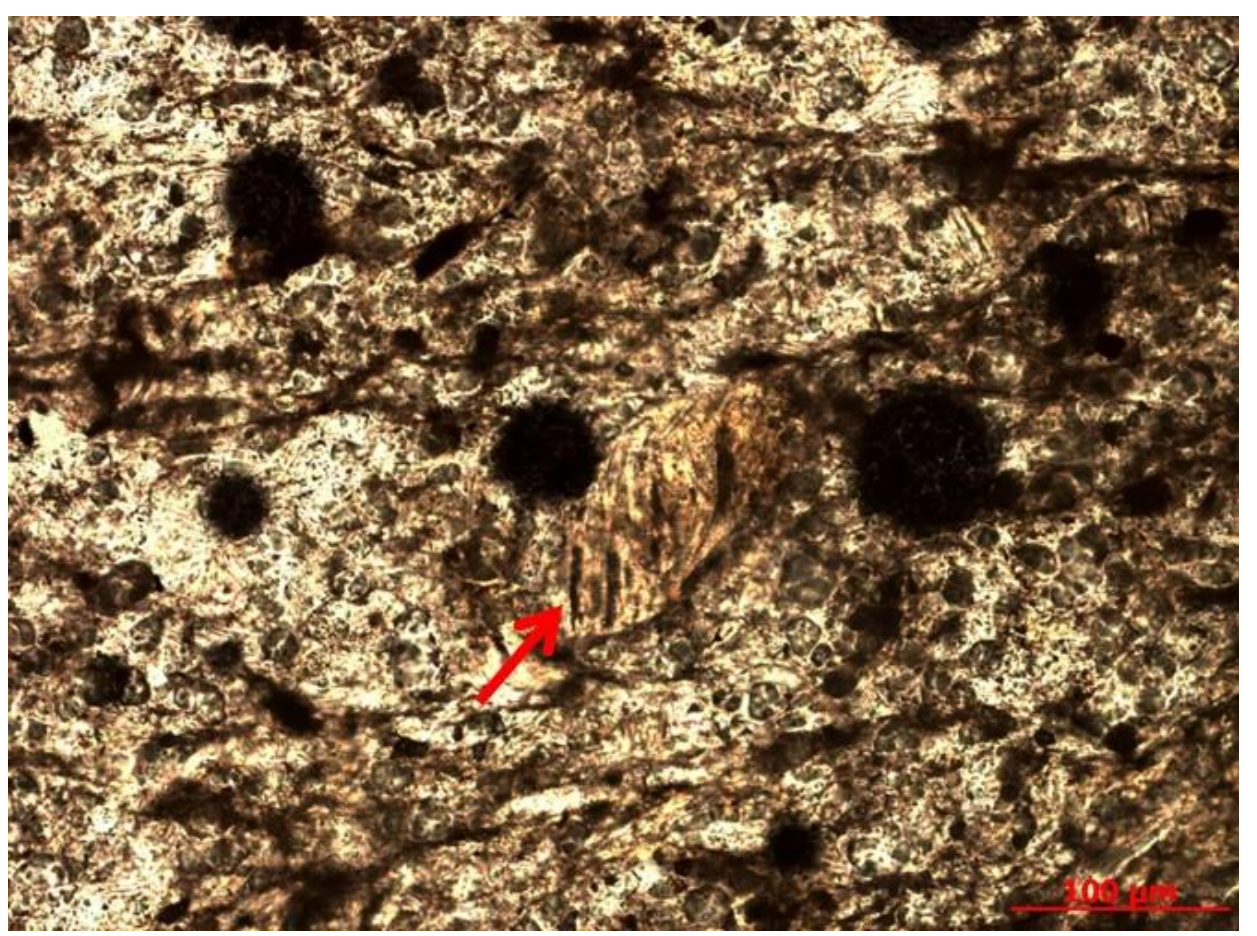

Em sentido anti-horário:

Figura 18 - Vermiculita indicada pela seta. Observar o desenvolvimento preferencial das palhetas ao longo do que possivelmente eram os planos de clivagem do anfibólio (Nicóis paralelos, ponto LS-008a).

Figura 19 - Grão de quartzo (destacado pela seta) exibindo crescimento secundário de sílica (Nicóis cruzados, ponto 12-IV-78).

Figura 20 - Cimento ferruginoso substituindo grãos de variados minerais e porções da matriz (Nicóis paralelos, ponto 11-III-84).
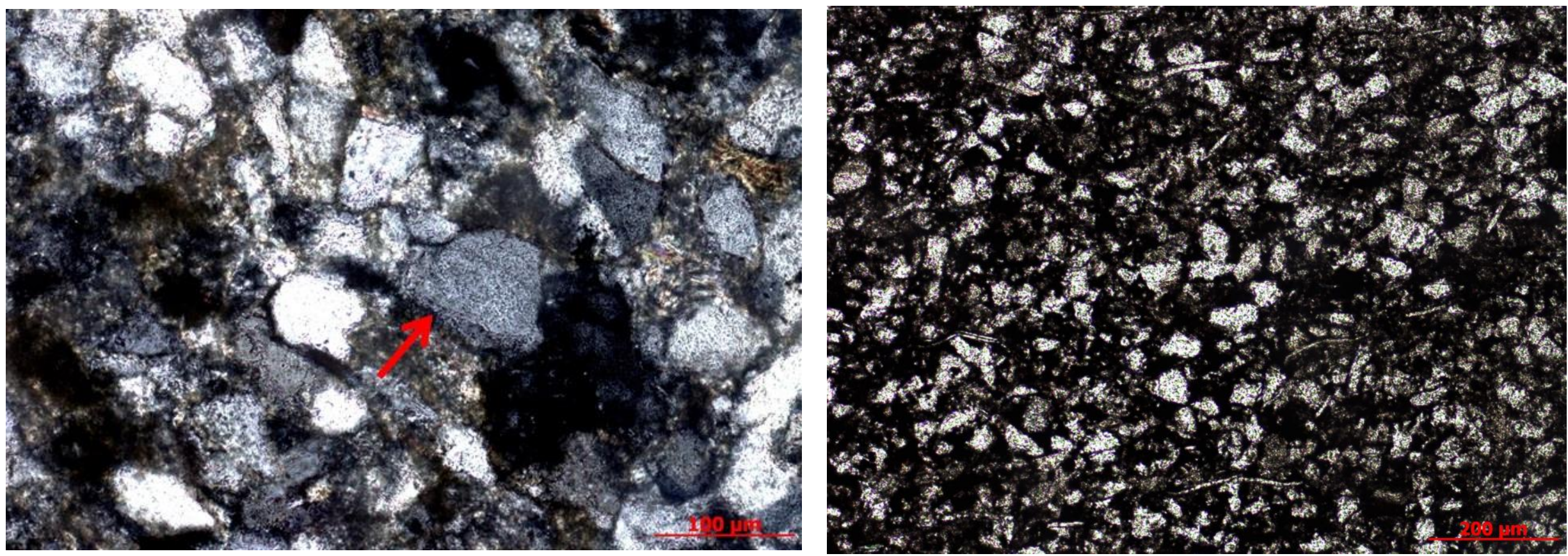


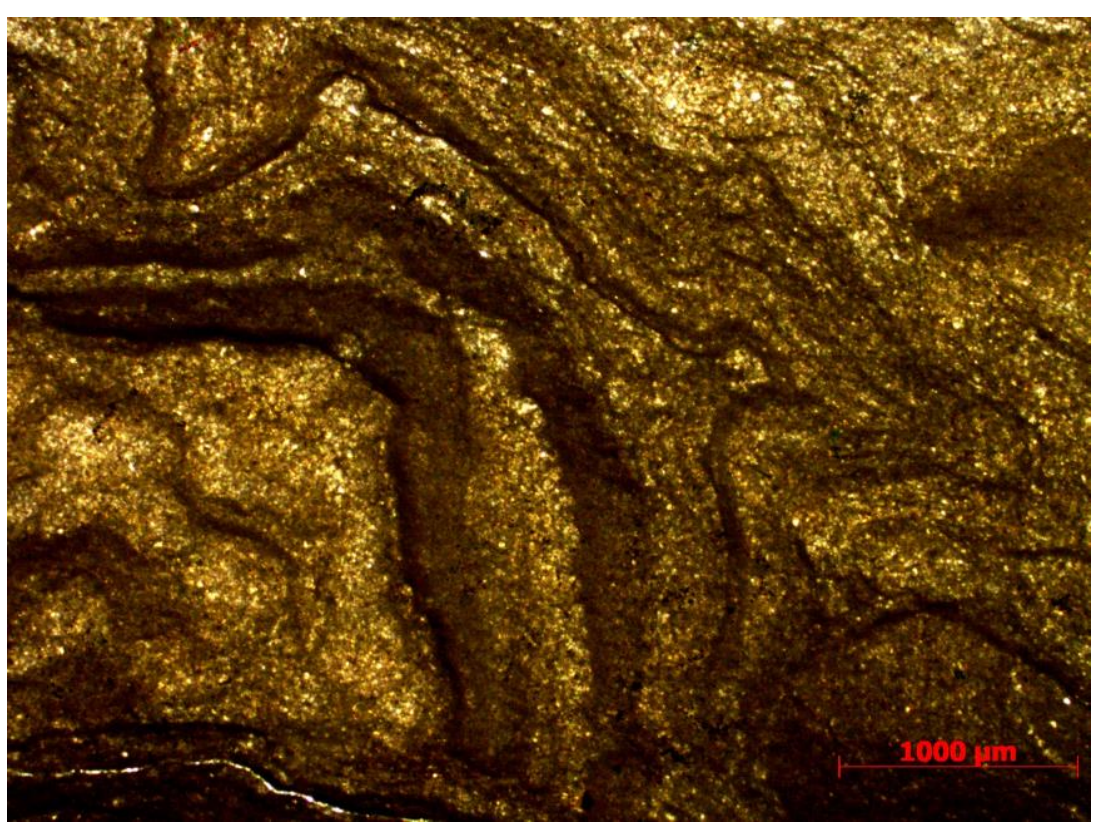

Em sentido anti-horário:

Figura 21 - Deformação sin-sedimentar. Observar a variação no conteúdo de argila das lâminas, evidenciada pela mudança de cor (Nicóis paralelos, ponto LS-005).

Figura 22 - Superfície de erosão marcando o limite entre laminações (laminação cruzada) (Nicóis paralelos, ponto LS-003).

Figura 23 - Acamamento gradacional. Observar a mudança brusca de granulometria ao passar de uma sequência para outra (Nicóis paralelos, ponto LS-001).
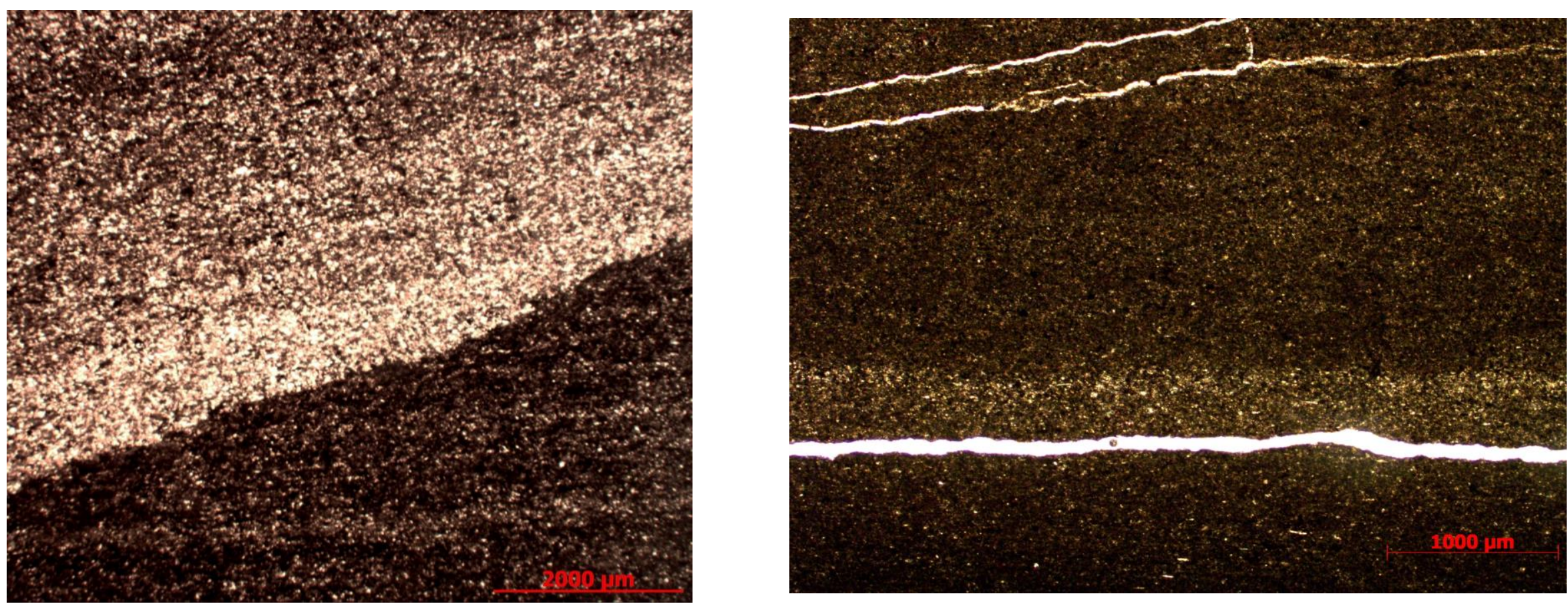


\section{5 .2 Geoquímica}

Os resultados das análises químicas são apresentados na tabela 6. Observa-se semelhança entre estes resultados e os valores apresentados na tabela 1 , com relação às porcentagens de óxidos. O índice CIA varia de 63 a 69, indicando intemperismo moderado na área fonte dos sedimentos. Algumas amostras exibiram CIA mais alto ( $>70)$, porém apresentavam sinais de alteração intempérica (presença de vermiculita) e, portanto, não serão levadas em conta na interpretação de proveniência.

Quando plotados em diagrama $\log \left(\mathrm{Na}_{2} \mathrm{O} / \mathrm{K}_{2} \mathrm{O}\right)$ versus $\mathrm{SiO}_{2}$ (figura 24), os dados mostram claramente um ambiente de margem continental ativa, o que condiz com o modelo foreland para o Grupo Bambuí. Já no diagrama de $\mathrm{TiO}_{2}$ vs $\mathrm{Fe}_{2} \mathrm{O}_{3}+\mathrm{MgO}$, plotam entre os campos de arco de ilhas oceânico e arco de ilhas continental (figura 25).

No diagrama de Roser \& Korsch (1988), os pontos plotam em sua maioria no campo P4, indicativo de rochas sedimentares quartzosas na área-fonte, porém alguns pontos plotam na divisa ou dentro do campo P3, indicativo de rochas félsicas (figura 26). No diagrama de Bathia (1983), os pontos plotam entre os campos de Margem Continental Ativa e Arco de llhas Continental (figura 27). No gráfico A-CN-K (figura 28), observa-se que o trend (linha tracejada) formado pelas análises indica rochas tonalíticas/granodioríticas na área-fonte Este último indica também um possível enriquecimento da rocha em potássio.

No diagrama de classificação petrográfica de Pettijohn et al. (1987), os dados são plotados entre o campo de litarenitos e o de grauvacas (figura 29), condizente com o resultado da análise das lâminas petrográficas. 
Tabela 6 - Resultados das análises por Fluorescência de Raios-X. P.F. - Perda ao Fogo; CIA - Índice de Alteração Química

\begin{tabular}{|c|c|c|c|c|c|c|c|c|c|c|c|c|}
\hline & $\mathrm{SiO2}(\%)$ & $\mathrm{Al} 2 \mathrm{O} 3$ & $\mathrm{MgO}$ & $\mathrm{Fe} 2 \mathrm{O} 3$ & $\mathrm{CaO}$ & $\mathrm{Na2O}$ & $\mathrm{K} 2 \mathrm{O}$ & TiO2 & P2O5 & MnO & P.F. & CIA \\
\hline LS - 001 & 58,85 & 17,21 & 3,79 & 8,00 & 0,27 & 1,32 & 4,73 & 0,94 & 0,15 & 0,07 & 4,60 & 73 \\
\hline 14-II-56 & 70,43 & 12,63 & 1,88 & 5,79 & 0,40 & 3,07 & 2,33 & 0,86 & 0,16 & 0,06 & 2,26 & 69 \\
\hline LS - 002 & 74,22 & 11,21 & 1,33 & 4,15 & 0,44 & 3,54 & 2,01 & 0,85 & 0,19 & 0,05 & 1,95 & 65 \\
\hline LS - 003 & 69,78 & 12,85 & 1,91 & 5,43 & 0,38 & 3,01 & 2,38 & 0,97 & 0,16 & 0,06 & 2,89 & 69 \\
\hline LS - 004 & 72,22 & 11,72 & 1,63 & 4,88 & 0,44 & 4,00 & 1,93 & 0,79 & 0,16 & 0,08 & 2,06 & 65 \\
\hline LS - 005 & 60,18 & 16,39 & 3,10 & 8,71 & 0,26 & 1,71 & 3,73 & 1,02 & 0,15 & 0,08 & 4,54 & 74 \\
\hline MP11-III-84 & 64,07 & 14,25 & 2,20 & 8,77 & 0,56 & 1,87 & 3,89 & 1,13 & 0,16 & 0,30 & 2,63 & 69 \\
\hline MP1-11-1-68 & 76,65 & 11,57 & 0,82 & 2,99 & 0,23 & 2,83 & 2,21 & 0,73 & 0,18 & 0,03 & 1,66 & 69 \\
\hline MG1-13-V-1 & 65,67 & 13,91 & 2,26 & 8,14 & 0,50 & 1,70 & 3,94 & 1,09 & 0,22 & 0,17 & 2,21 & 69 \\
\hline MP1-11-II-78 & 75,16 & 10,42 & 1,49 & 3,58 & 0,58 & 2,71 & 2,81 & 0,71 & 0,20 & 0,03 & 1,61 & 63 \\
\hline LS - 006 & 76,23 & 10,47 & 0,98 & 3,49 & 0,77 & 3,38 & 1,58 & 0,83 & 0,20 & 0,03 & 1,88 & 65 \\
\hline LS - 007 & 73,80 & 10,72 & 1,15 & 4,44 & 1,14 & 3,11 & 1,90 & 1,06 & 0,27 & 0,04 & 2,25 & 64 \\
\hline LFDF-006 & 72,37 & 10,41 & 2,12 & 7,24 & 0,10 & 0,04 & 4,61 & 0,99 & 0,07 & 0,01 & 1,92 & 69 \\
\hline LS-008A & 60,59 & 17,24 & 2,52 & 7,79 & 0,33 & 1,33 & 4,92 & 1,03 & 0,18 & 0,10 & 3,85 & 72 \\
\hline
\end{tabular}




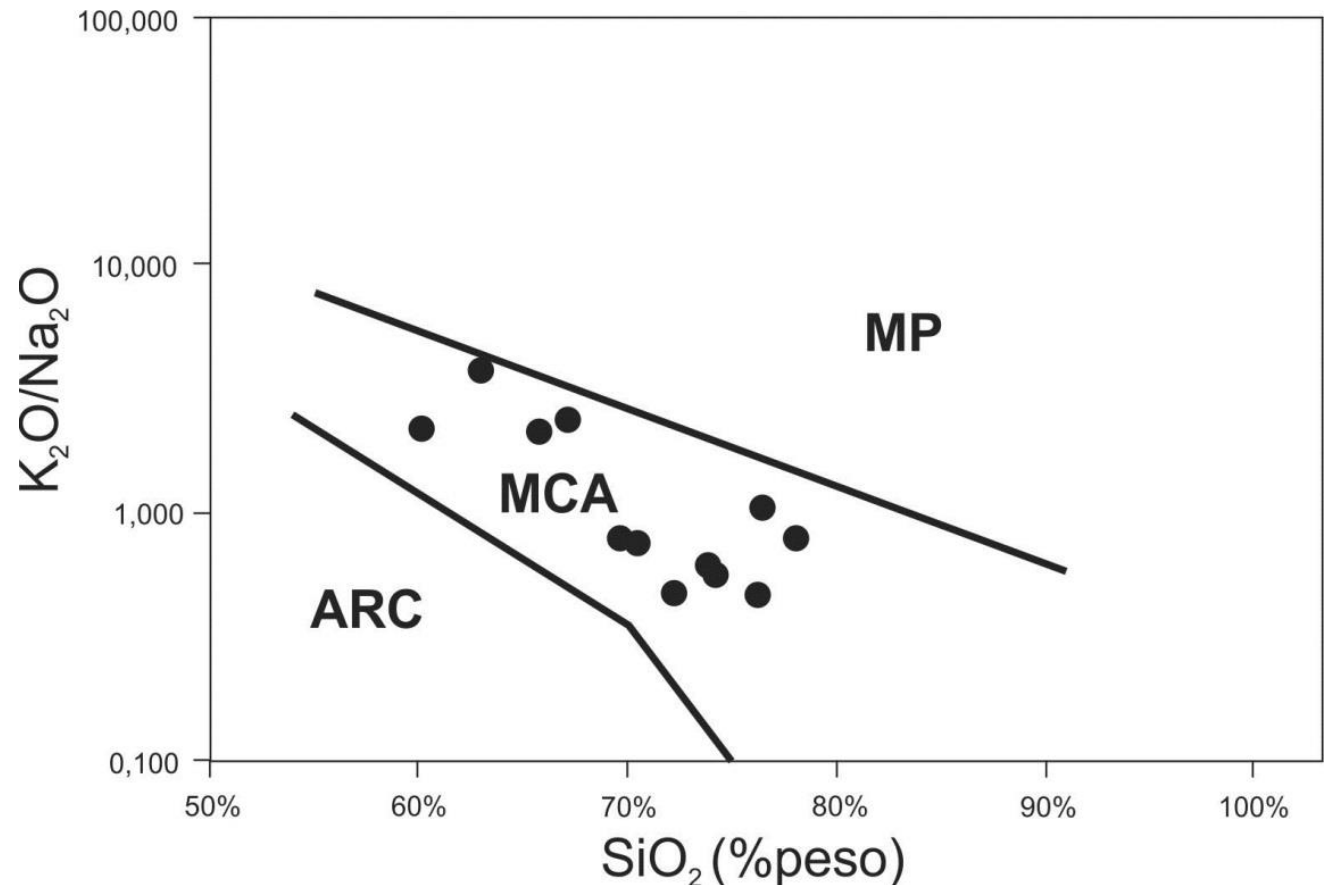

Figura 24 - Gráfico de $\mathrm{K}_{2} \mathrm{O} / \mathrm{Na}_{2} \mathrm{O}$ versus $\mathrm{SiO}_{2}$ (Roser \& Korsch 1986). MP - Margem Passiva; MCA - Margem Continental Ativa; ARC - Arco de llhas.

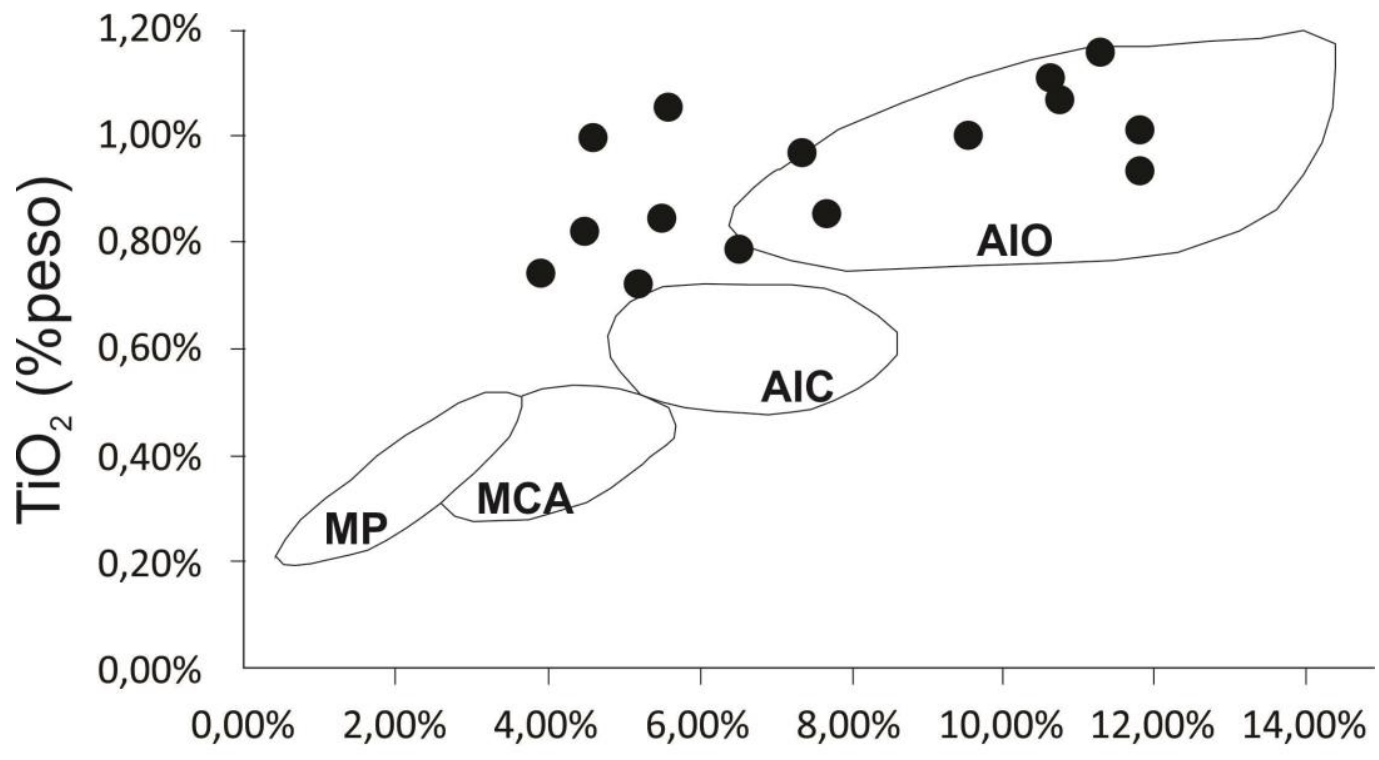
$\mathrm{Fe}_{2} \mathrm{O}_{3}+\mathrm{MgO}$ (\%peso)

Figura 25 - Diagrama de TiO2 vs Fe2O3+MgO (Bathia 1983). MP - Margem Passiva; MCA Margem Continental Ativa; AIC - Arco de llhas Continental; AIO - Arco de llhas Oceânico. 


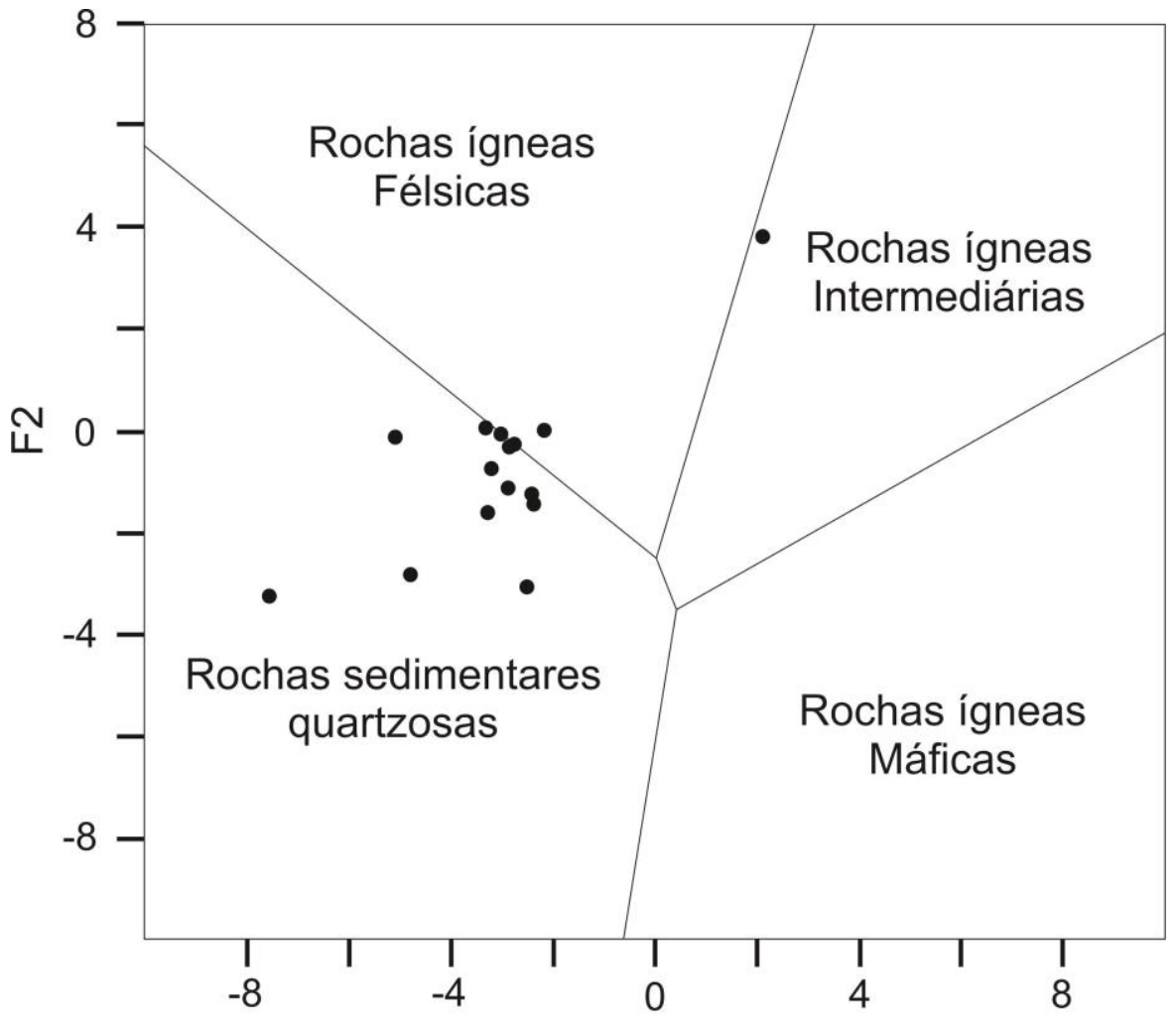

F1

Figura 26 - Diagrama discriminante de Roser \& Korsch (1988).

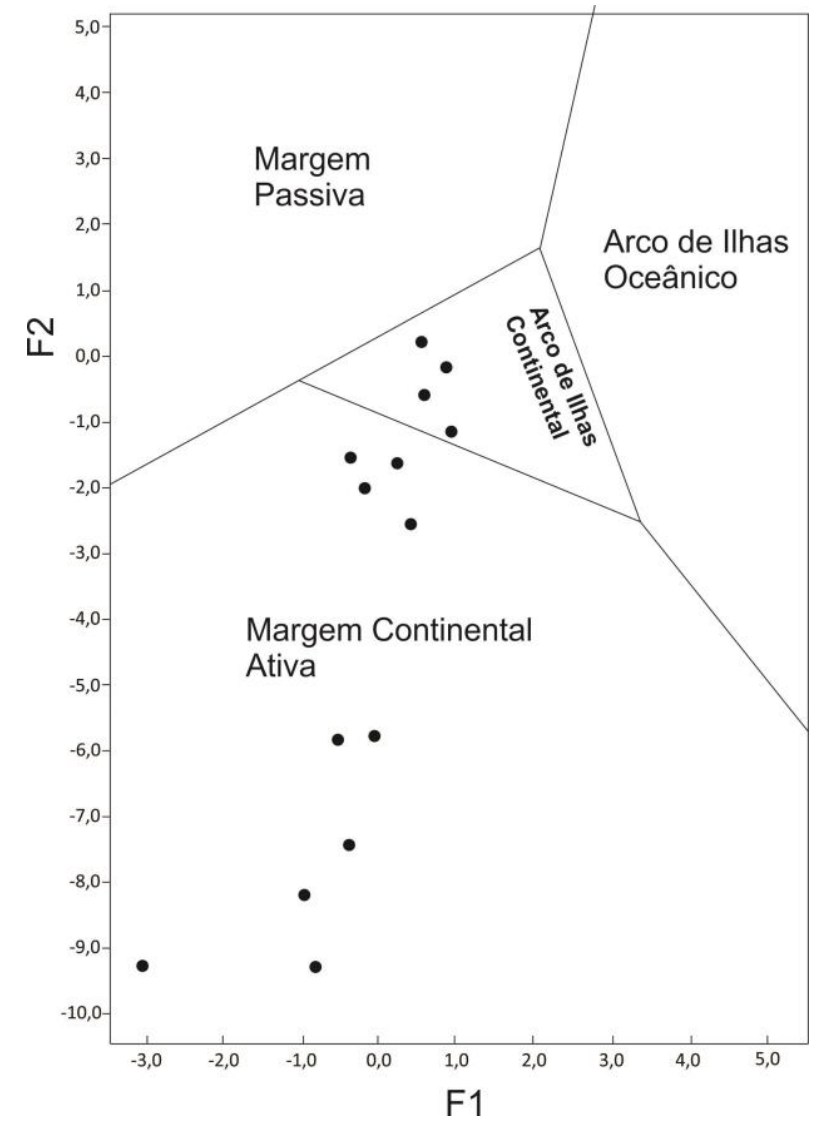

Figura 27 - Diagrama discriminante de Bathia (1983). Os pontos se distribuem entre os campos de Arco de llhas Continental e Margem Continental Ativa. 


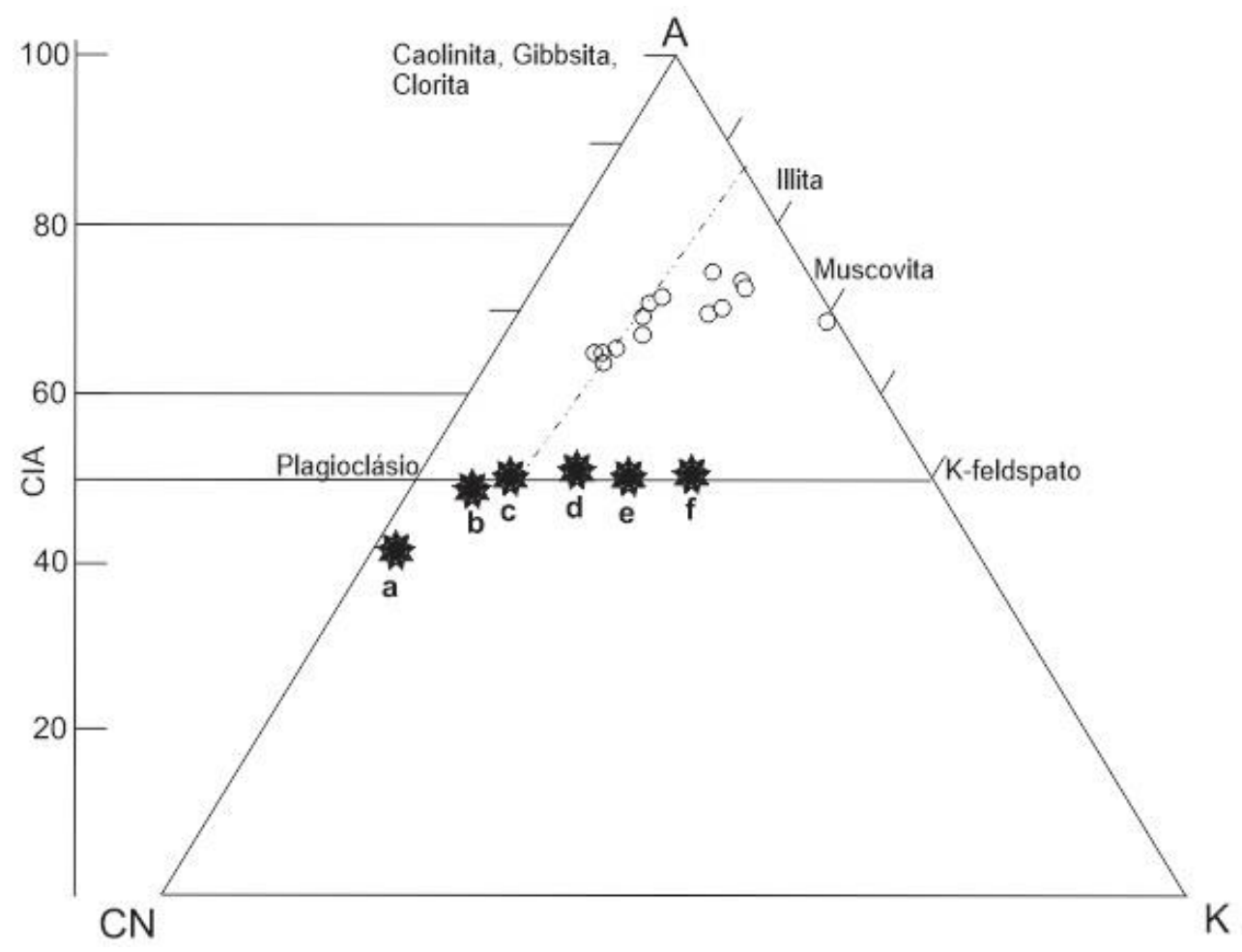

Figura 28 - Os asteriscos indicam a composição com o valor mínimo de CIA para variados tipos de rocha. A linha tracejada representa 0 trend de alteração. Os círculos vazios correspondem aos valores encontrados para as rochas da Fm. SSH. a) Gabro; b) Tonalito; c) Granodiorito; d) Granito; e) Granito tipo A; f) Charnoquito.

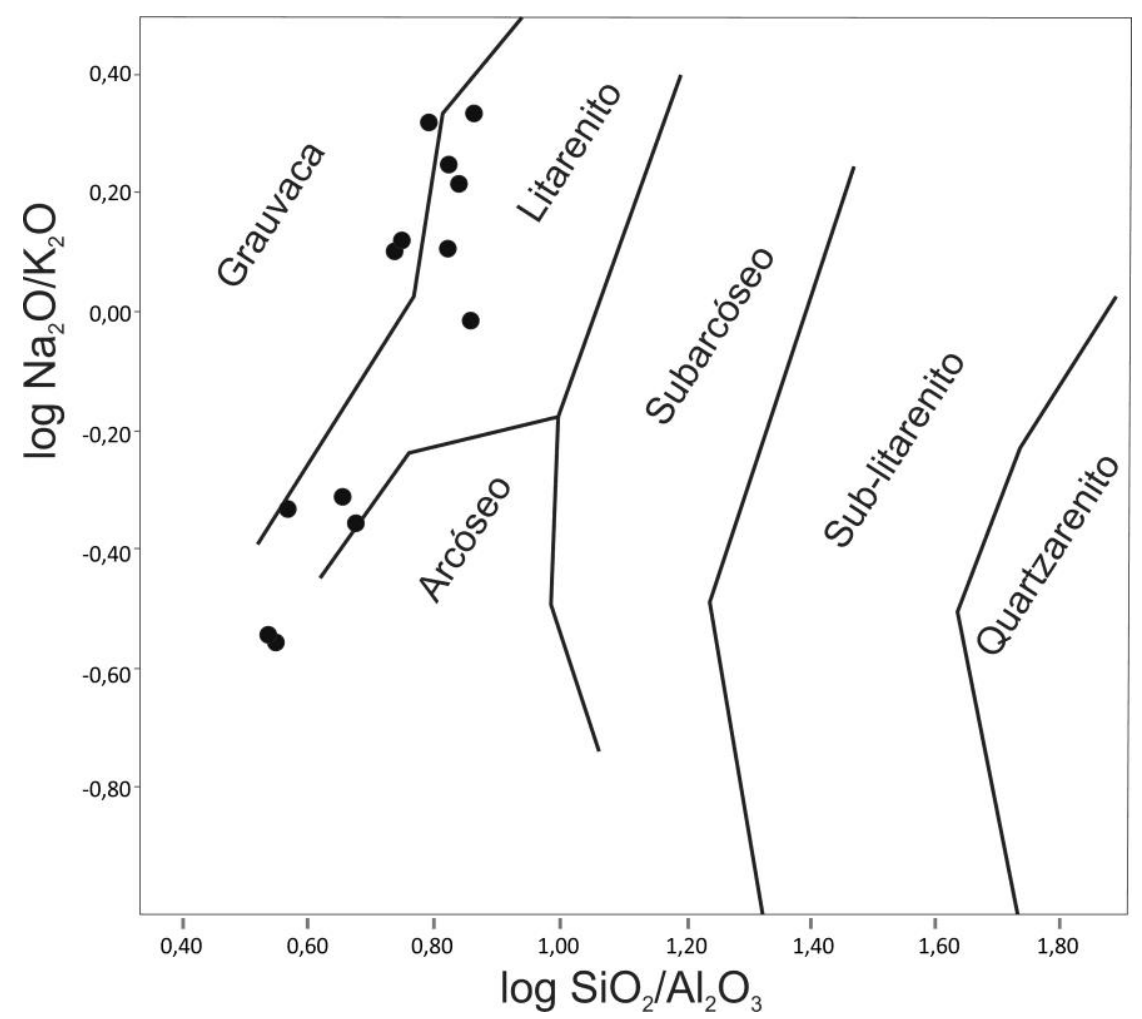

Figura 29 - Diagrama de classificação de Pettijohn. As amostras não alteradas se distribuem entre os campos de litarenitos e grauvacas.

\subsection{Desagregação das amostras e separação dos argilominerais}

Os valores de FWHM das reflexões 001 da illita foram medidos tanto nos difratogramas da fração argila seca ao ar quanto solvatada com etileno-glicol, de amostras preparadas tanto com o 
moinho McCrone quanto com o morteiro, sendo os resultados apresentados na tabela 7 e na figura 30 .

Tabela 7 - Largura à meia altura, em ${ }^{\circ} \Delta 2 \theta$, das amostras desagregadas com o Moinho McCrone e com morteiro, secas ao ar e tratadas com etileno-glicol. N - Fração argila orientada e seca ao ar; G - Fração argila orientada e solvatada com etileno-glicol.

\begin{tabular}{|c|c|c|c|c|}
\hline & McCrone $\mathbf{N}$ & McCrone G & Morteiro N & Morteiro G \\
\hline Amostras & $\begin{array}{c}\text { Illita } \\
001\end{array}$ & $\begin{array}{c}\text { Illita } \\
001\end{array}$ & $\begin{array}{c}\text { Illita } \\
001\end{array}$ & $\begin{array}{c}\text { Illita } \\
001\end{array}$ \\
\hline LS-001 & 0,362 & 0,338 & 0,361 & 0,347 \\
\hline LS-002 & 0,240 & 0,255 & 0,355 & 0,350 \\
\hline LS-003 & 0,333 & 0,278 & 0,374 & 0,354 \\
\hline LS-004 & 0,236 & 0,263 & 0,381 & 0,354 \\
\hline LS-005 & 0,409 & 0,378 & 0,341 & 0,298 \\
\hline $14-I I-56$ & 0,336 & 0,331 & 0,407 & 0,387 \\
\hline LS-006 & 0,244 & 0,259 & 0,276 & 0,267 \\
\hline LS-007 & 0,283 & 0,248 & 0,246 & 0,239 \\
\hline
\end{tabular}

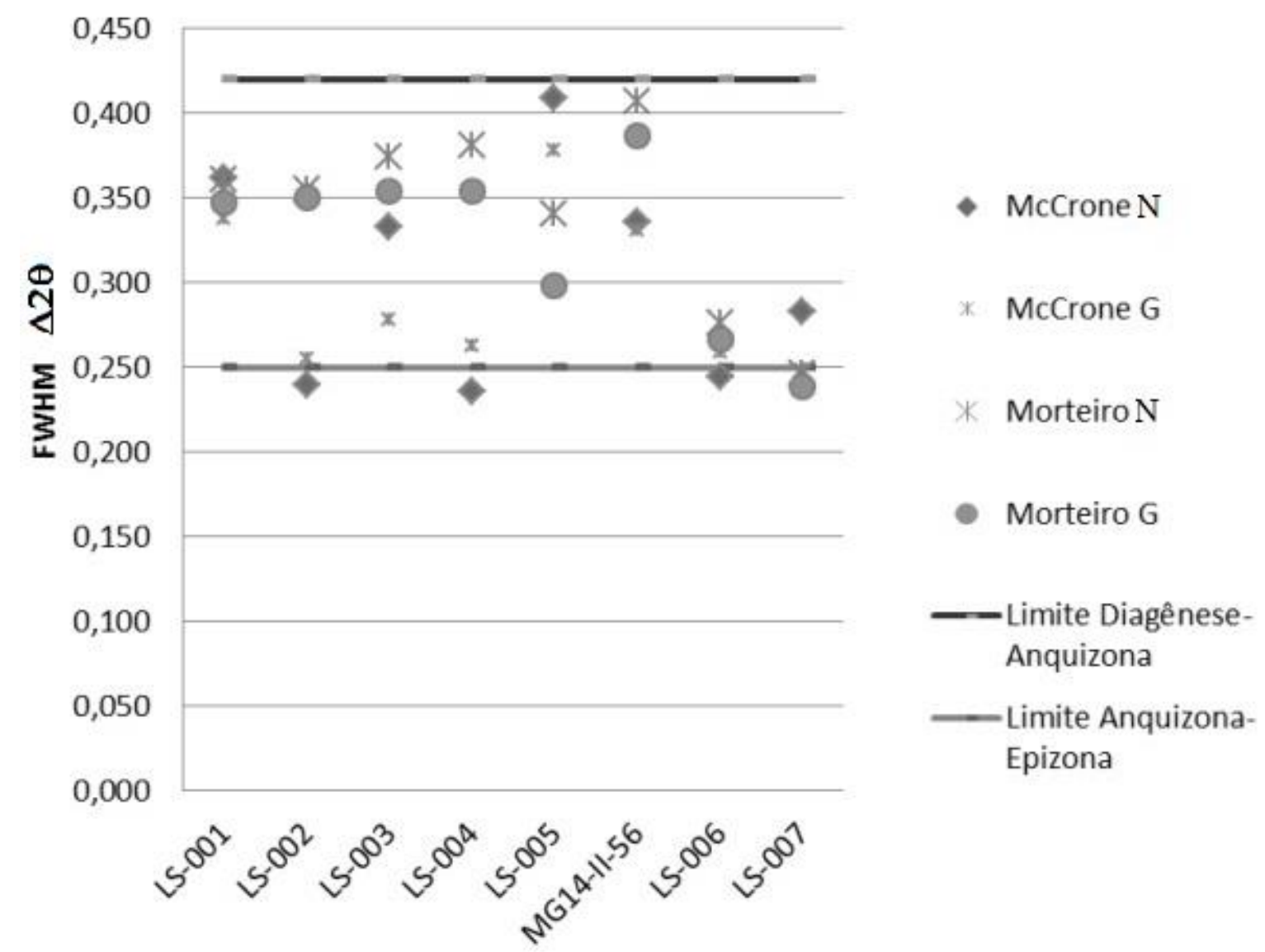

Figura 30 - Comparação entre os valores de largura à meia altura das amostras preparadas com o Moinho McCrone e o morteiro. N - Fração argila orientada e seca ao ar; G - fração argila orientada e solvatada com etileno-glicol.

As amostras preparadas com o moinho McCrone mostraram reflexões mais intensas para rochas menos coesas, enquanto a separação dos argilominerais nas rochas mais coesas não foi muito eficiente. Já as análises das amostras preparadas com morteiro mostraram uma separação eficiente dos argilominerais tanto nas amostras menos coesas quanto nas mais coesas. No entanto, apenas na preparação com o moinho McCrone foi possível separar a fração $<0.2 \mu \mathrm{m}$. Uma comparação entre os resultados do McCrone com o morteiro em amostras com alta e baixa coesão é apresentada nas figuras 31 e 32.

Observou-se um aumento relativo da intensidade das reflexões dos argilominerais, em relação ao quartzo e à albita, mais proeminente nas amostras preparadas com o morteiro do que 
naquelas preparadas com o moinho McCrone. É possível notar também que as amostras preparadas com o morteiro apresentam um padrão definido nos valores de FWHM, enquanto aquelas preparadas com o McCrone apresentam distribuição aleatória.

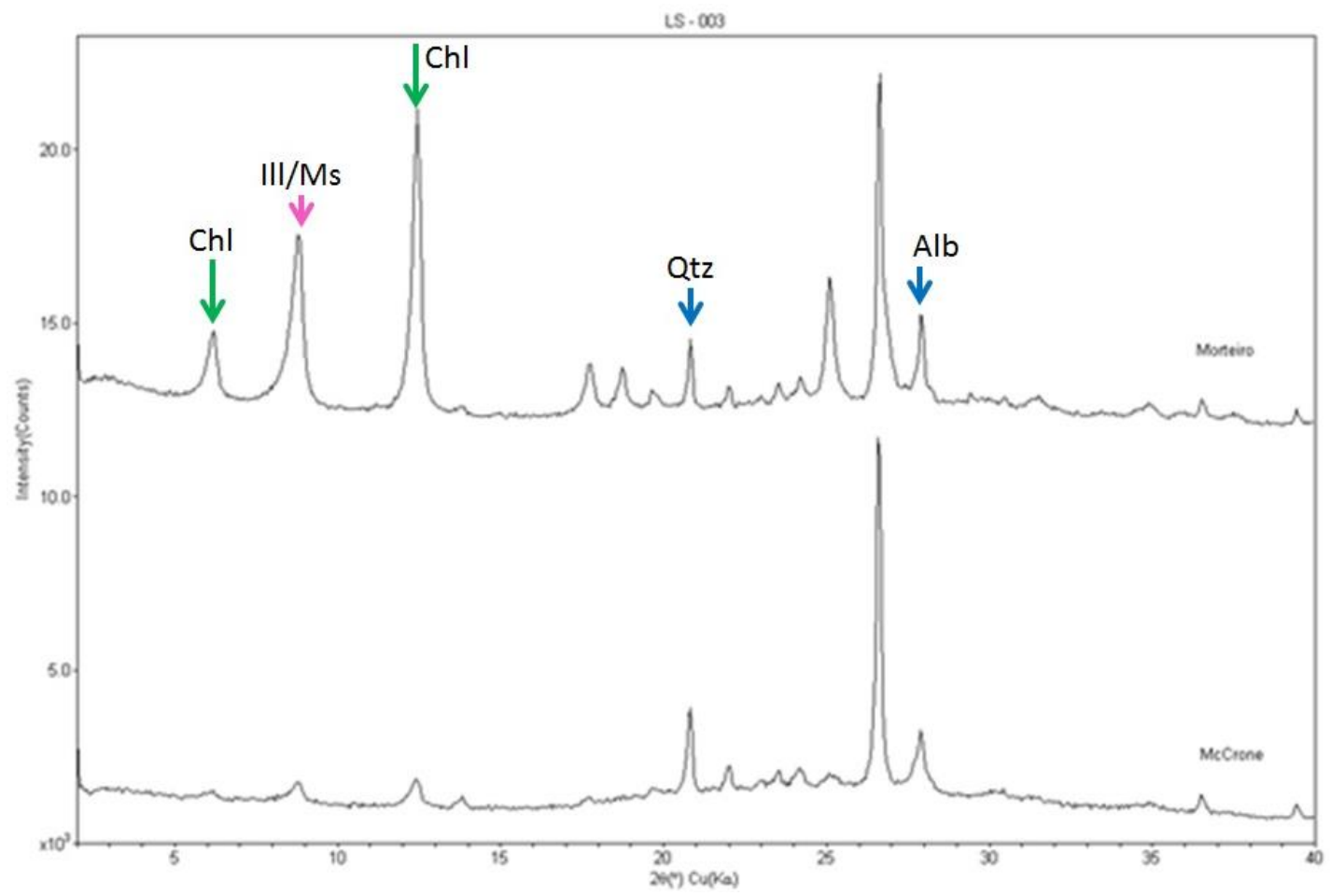

Figura 31 - Comparação entre os resultados do morteiro (superior) e McCrone (inferior) para a fração argila da amostra LS-003 (altamente coesa). Chl - Clorita; III - Illita; Ms - Muscovita; Qtz Quartzo; Alb - Albita.

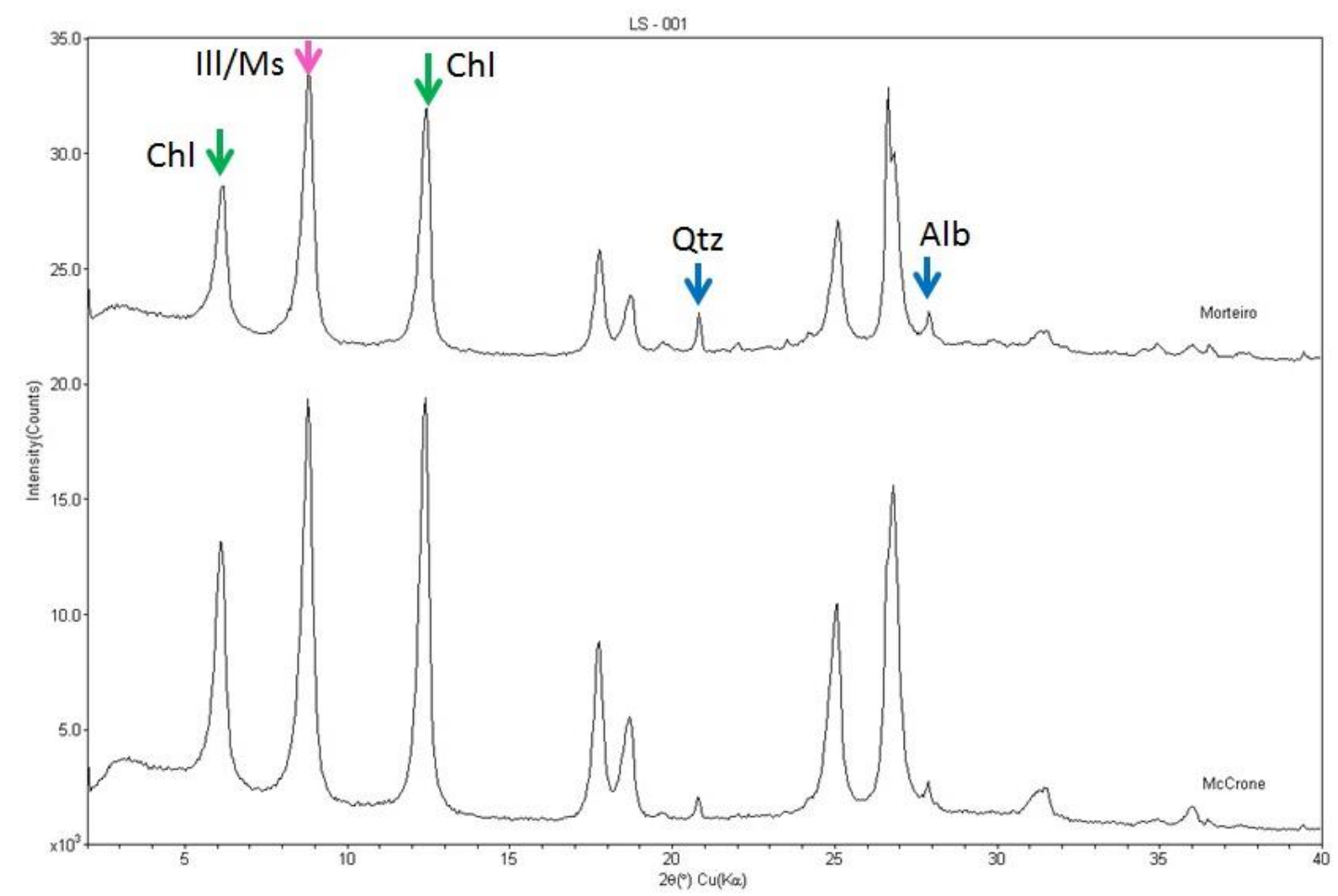

Figura 32 - Comparação entre os resultados do morteiro (superior) e McCrone (inferior) para a fração argila da amostra LS-001 (pouco coesa). Chl - Clorita; III - Illita; Ms - Muscovita; Qtz Quartzo; Alb - Albita. 


\subsection{Difratometria de Raios-X}

A mineralogia identificada por difratometria de raios- $X$ para cada amostra é apresentada na tabela 8.

Tabela 8 - Minerais identificados na análise de rocha total e fração argila por DRX. N Fração argila seca ao ar. Qtz - Quartzo; PI - Plagioclásio; Kfs - Feldspato potássico; Chl Clorita; III - Illita; Ms - Muscovita; Hem - hematita; Vrm - Vermiculita; Smc - Esmectita; M constituinte maior; m - constituinte menor; tr - constituinte traço.

\begin{tabular}{|c|c|c|c|c|c|c|}
\hline Amostra & Qtz & PI & Kfs & Chl & III/Ms & Outros \\
\hline LS-001 & $M$ & $m$ & - & ṃ & ṃ & - \\
\hline $\mathbf{N}$ & ṃ & - & - & $M$ & $M$ & Vrm - ṃ \\
\hline 14-II-56 & $M$ & ṃ & - & $\operatorname{tr}$ & $\operatorname{tr}$ & - \\
\hline $\mathbf{N}$ & ṃ & $\operatorname{tr}$ & - & $M$ & $M$ & - \\
\hline LS-002 & $M$ & ṃ & - & $\operatorname{tr}$ & $\operatorname{tr}$ & - \\
\hline $\mathbf{N}$ & ṃ & $\operatorname{tr}$ & - & $M$ & $M$ & - \\
\hline LS-003 & $M$ & ṃ & - & $\operatorname{tr}$ & $\operatorname{tr}$ & - \\
\hline $\mathbf{N}$ & ṃ & $\operatorname{tr}$ & - & $M$ & $M$ & - \\
\hline LS-004 & $M$ & ṃ & - & $\operatorname{tr}$ & $\operatorname{tr}$ & - \\
\hline $\mathbf{N}$ & ṃ & $\operatorname{tr}$ & - & $M$ & ṃ & - \\
\hline LS-005 & $M$ & ṃ & - & ṃ & ṃ & - \\
\hline $\mathbf{N}$ & ṃ & - & - & M & $M$ & Vrm - m \\
\hline LS-006 & M & ṃ & - & $\operatorname{tr}$ & $\operatorname{tr}$ & - \\
\hline $\mathbf{N}$ & M & ṃ & - & ṃ & ṃ & - \\
\hline LS-007 & $M$ & $m$ & - & $\operatorname{tr}$ & $\operatorname{tr}$ & - \\
\hline $\mathbf{N}$ & M & $m$ & - & $M$ & ṃ & - \\
\hline 11-I-68 & $M$ & ṃ & $\operatorname{tr}$ & $\operatorname{tr}$ & $\operatorname{tr}$ & - \\
\hline $\mathbf{N}$ & $M$ & ṃ & $\operatorname{tr}$ & $\operatorname{tr}$ & $\operatorname{tr}$ & - \\
\hline 11-II-76 & $M$ & - & - & - & - & - \\
\hline $\mathbf{N}$ & M & - & - & - & - & - \\
\hline 11-II-78 & M & ṃ & $M$ & $\operatorname{tr}$ & $\operatorname{tr}$ & - \\
\hline $\mathbf{N}$ & M & M & $\operatorname{tr}$ & M & ṃ & - \\
\hline 11-III-84 & $M$ & $m$ & - & m! & ṃ & Hem - tr \\
\hline $\mathbf{N}$ & $M$ & $m$ & - & M & $M$ & Hem - tr \\
\hline 12-IV-78 & $M$ & ṃ & - & $\operatorname{tr}$ & $\operatorname{tr}$ & - \\
\hline $\mathbf{N}$ & $M$ & M & $\operatorname{tr}$ & ṃ & ṃ & Vrm - tr \\
\hline $13-V-1$ & $M$ & ṃ & - & $\operatorname{tr}$ & $\operatorname{tr}$ & - \\
\hline $\mathbf{N}$ & $M$ & ṃ & - & $\mathrm{M}$ & $M$ & - \\
\hline LFDF006 & $M$ & ṃ & $\mathrm{M}$ & $\operatorname{tr}$ & $\operatorname{tr}$ & \\
\hline $\mathbf{N}$ & $M$ & $M$ & - & $\mathrm{M}$ & $\mathrm{M}$ & \\
\hline
\end{tabular}




\begin{tabular}{ccccccc} 
LFDF006.2 & M & $m$ & - & $m$ & $m$ & \\
\hline $\mathbf{N}$ & $M$ & $M$ & - & $M$ & $M$ & Smc $-m$ \\
\hline LS-008a & $M$ & $m$ & - & $m$ & $m$ & \\
\hline $\mathbf{N}$ & $M$ & $m$ & - & - & $M$ & Vrm - m \\
\hline LS-008b & $M$ & $m$ & - & $m$ & $m$ & \\
\hline $\mathbf{N}$ & $M$ & $m$ & - & tr & $M$ & Vrm $-\mathrm{m}$ \\
\hline
\end{tabular}

A partir dos difratogramas foi possível identificar uma associação básica que se repete em praticamente todas as amostras, composta por quartzo, muscovita/illita, clorita (clinocloro) e plagioclásio (albita) (figura 33). O constituinte maior de todas as amostras é o quartzo, acompanhado de plagioclásio. Clorita e muscovita/illita ocorrem como traço, exceto nas amostras mais intemperizadas, nas quais são constituintes menores. Na amostra 11-III-84 foi identificada também hematita (figura 34). Feldspato potássico (microclínio) ocorre como traço em algumas amostras (figura 35).

$\mathrm{Na}$ fração argila nota-se diminuição da intensidade das reflexões do quartzo e do plagioclásio, sinal de que estes constituintes do arcabouço são maiores que a fração argila e foram efetivamente removidos nesta fração. A fração argila também proporcionou o aumento relativo das reflexões da clorita e illita, que passam a ser constituintes maiores. Hematita continua presente na fração argila da amostra 11-III-84.

Com o tratamento com etileno-glicol, verificou-se o alargamento da reflexão da illita em algumas análises, além do aparecimento de nova reflexão em d 17 Å nas amostras LS-008a, LS008b e LFDF006.2, indício da presença de argilominerais expansivos (esmectitas) (figura 36).

Após o tratamento por aquecimento, todas as amostras apresentaram diminuição da intensidade das reflexões do clinocloro, no entanto em alguns casos observou-se ligeiro aumento de intensidade da reflexão com $\mathrm{d} \sim 14 \AA$. Em algumas amostras, após o tratamento por aquecimento, verificou-se o surgimento de uma reflexão pouco definida com $d \sim 12 \AA$, interpretada como vermiculita (figura 37).

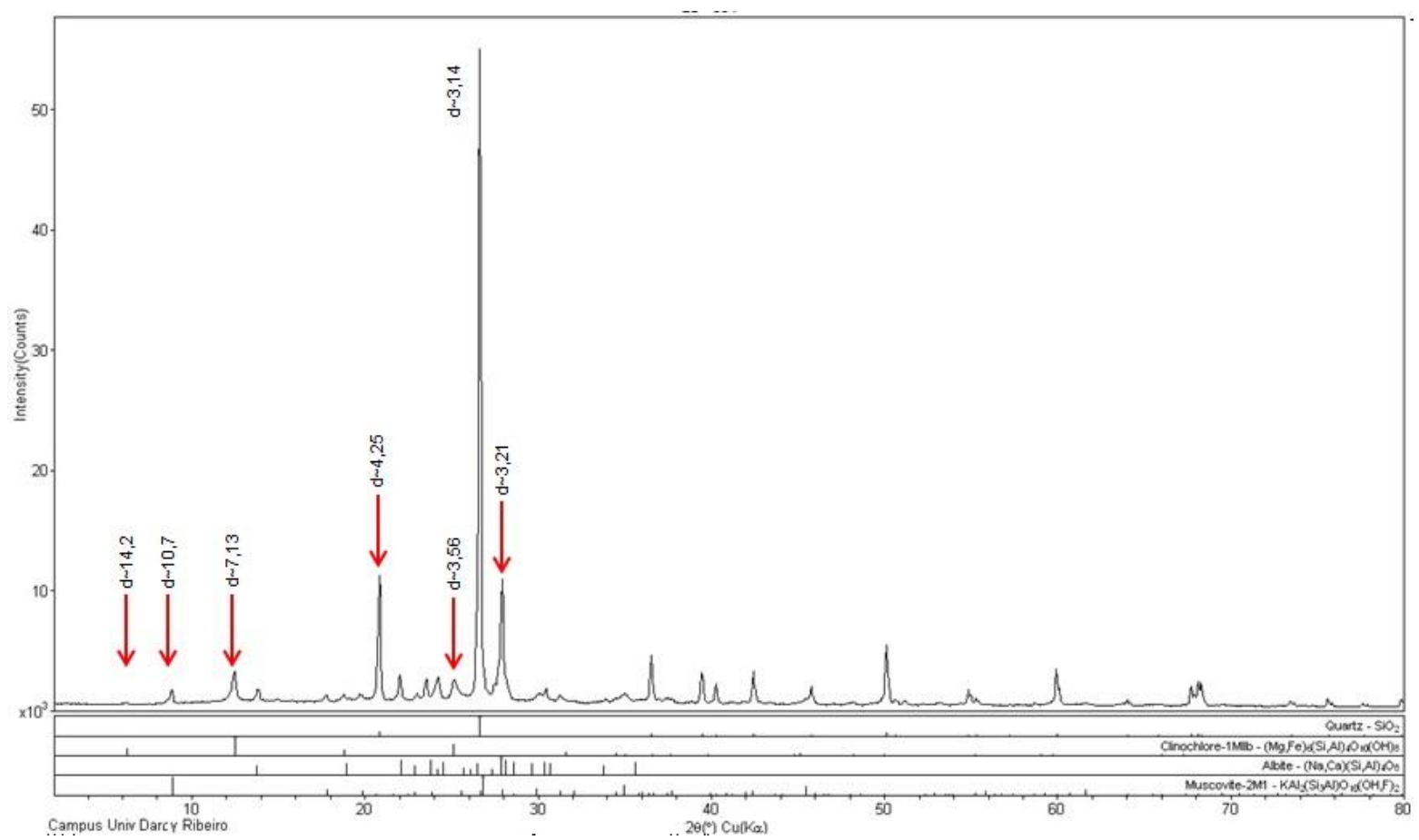

Figura 33 - Difratograma de rocha total da amostra LS-004, representativo da mineralogia das amostras analisadas. 


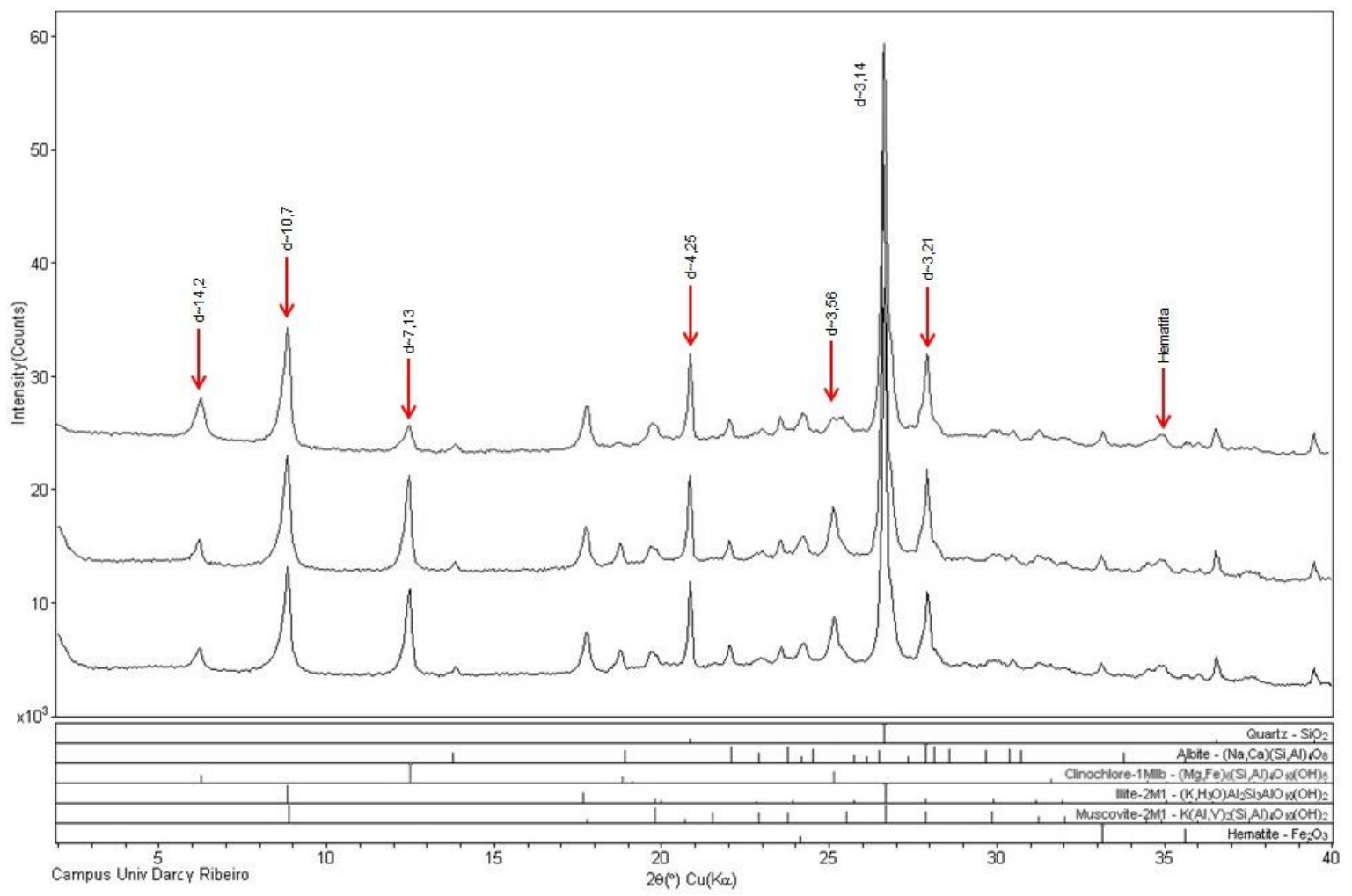

Figura 34 - Difratogramas da fração argila $(N)$, solvatada com etileno-glicol $(G)$ e aquecida $(A)$ da amostra 11-III-84

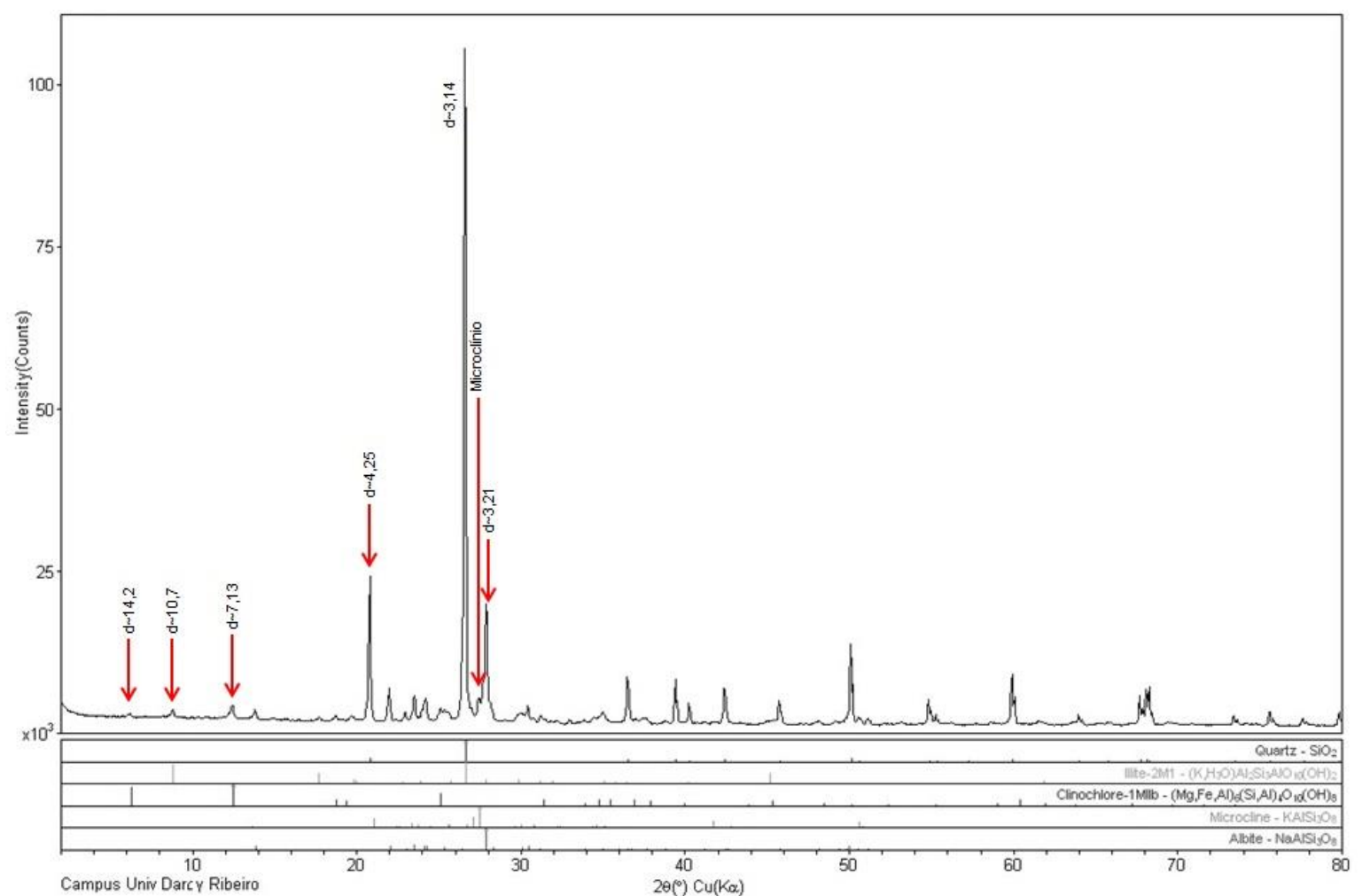

Figura 35 - Difratograma de rocha total da amostra 11-II-78. Observar a reflexão do microclínio assinalada. 


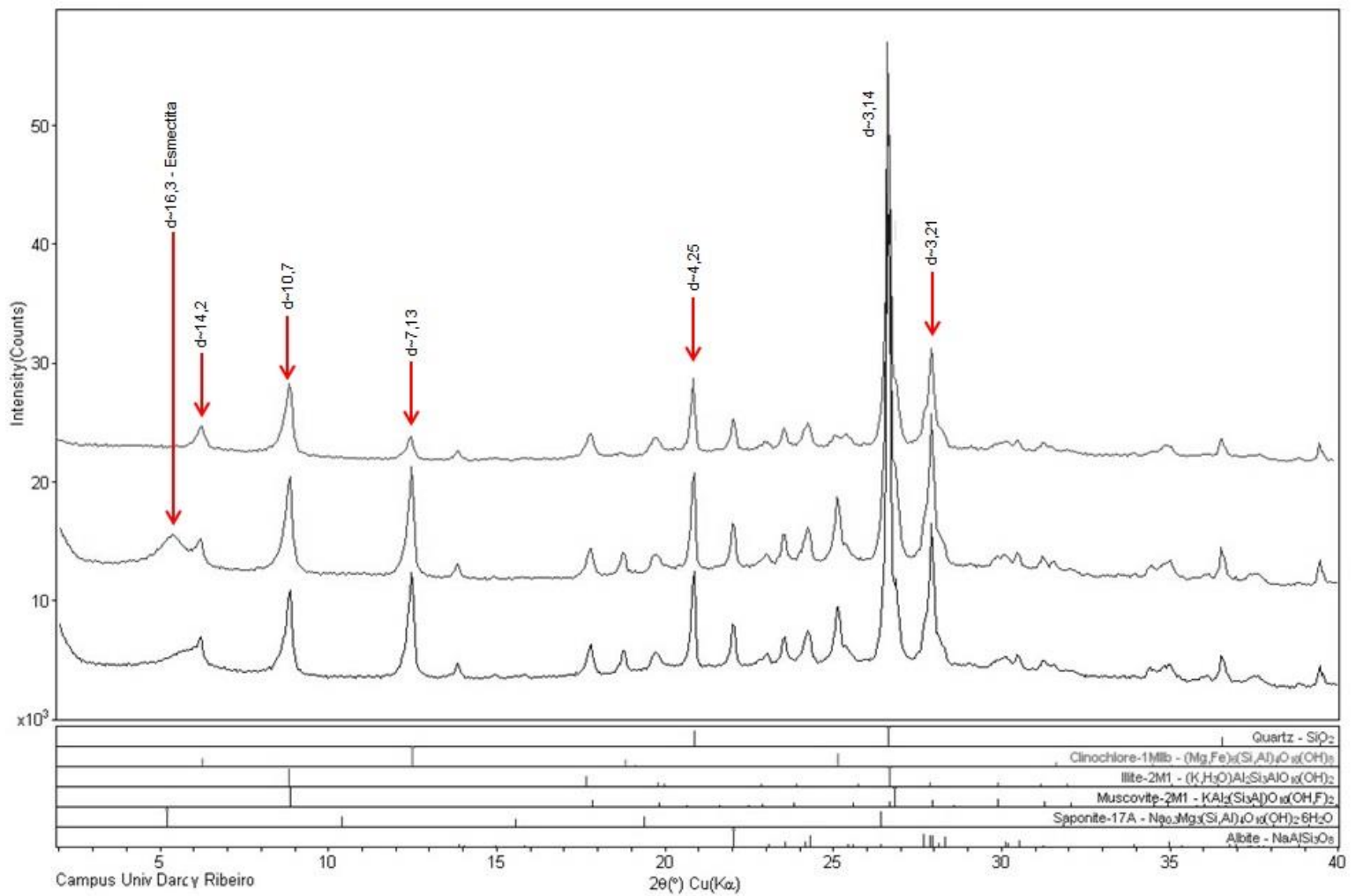

Figura 36 - Difratogramas da fração argila $(N)$, solvatada com etileno-glicol $(G)$ e aquecida $(A)$ da amostra LFDF006.2. Observar a reflexão da esmectita assinalada.

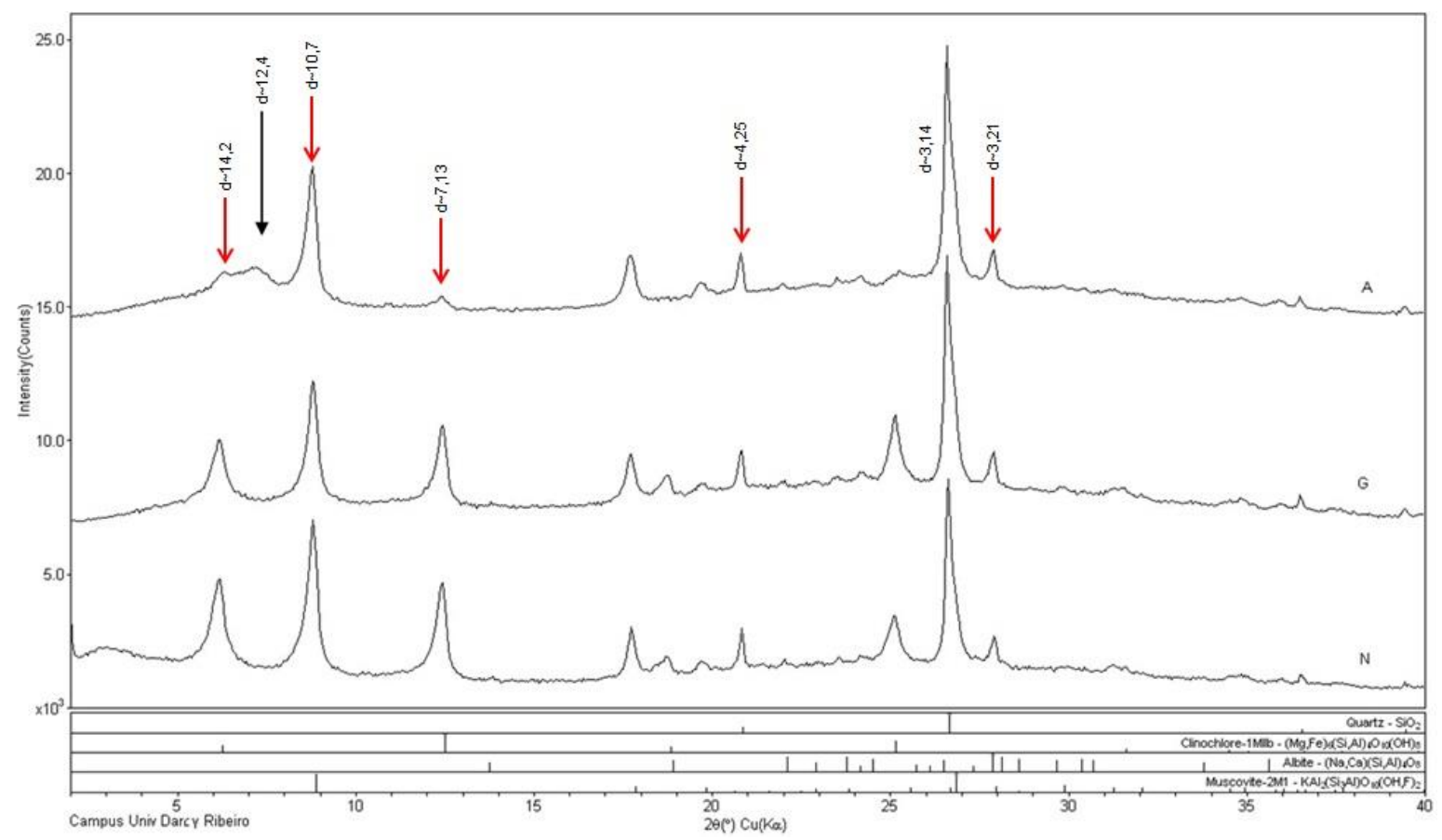

Figura 37 - Difratogramas da fração argila $(N)$, solvatada com etileno-glicol $(G)$ e aquecida $(A)$ da amostra LS-005. a reflexão próxima a 12,4Å (seta) é atribuída à vermiculita.

As amostras LFDF006, LFDF006.2, e possivelmente LS-007, 13-V-1, 11-II-78 e 11-III-84 apresentam o politipo $2 \mathrm{M} 2$ da illita, enquanto as outras amostras apresentam o politipo 2M1. Isso pode representar um estágio mais avançado de diagênese (anquizona), tendo em vista que ao menos as três primeiras amostras citadas se encontram próximas ao empurrão do Grupo Canastra. 
Para este trabalho, foram utilizados somente os dados das amostras desagregadas com morteiro. A figura 38 apresenta os valores de FWHM deste trabalho (losangos) comparados aos obtidos por Bonhomme (1986, quadrados) na região centro-norte de Minas Gerais, mais de $200 \mathrm{~km}$ a leste da Serra de São Domingos, já no domínio não deformado sobre o Cráton São Francisco. Os dados utilizados para conversão dos valores de Bonhomme (1986), em mm, para ${ }^{\circ} \Delta 2 \theta$, foram obtidos em Kisch (1991).

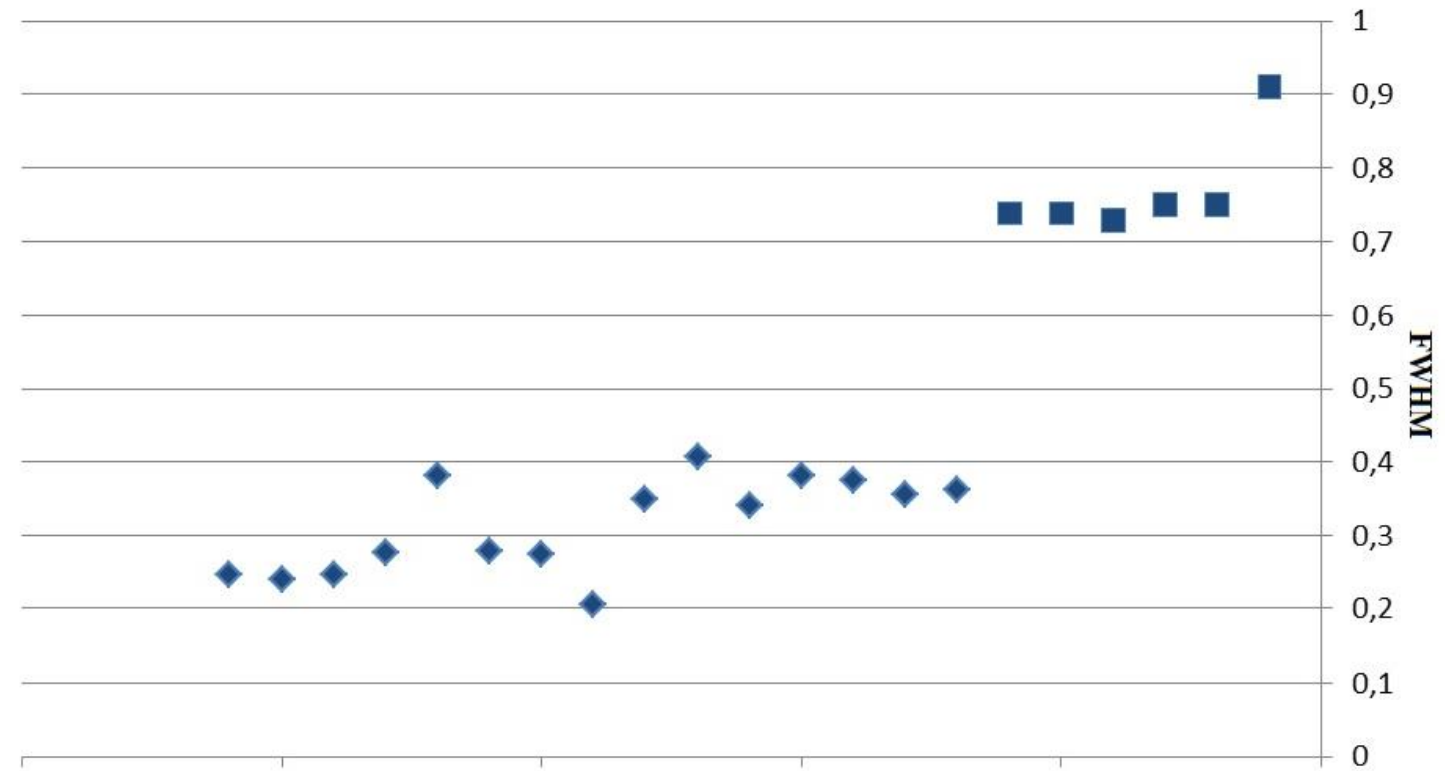

Figura 38 - Valores de FWHM, em ${ }^{\circ} \Delta 2 \theta$, de Bonhomme (1986) (quadrados) e deste trabalho (losangos).

A decomposição foi realizada nos difratogramas das amostras secas ao ar e solvatadas com etileno-glicol (tabela 9 e exemplo na figura 39). Os valores de FWHM obtidos mostram claramente, mesmo sem a utilização da decomposição, uma tendência de valores maiores na região de Buritis-MG (próximos ao limite diagênese-anquizona), diminuindo gradualmente para oeste até valores próximos do limite anquizona-epizona na região do norte do Distrito Federal. Os resultados mostram a presença de ao menos duas fases, uma mais cristalina (série 1), entre anquizona e epizona (FWHM entre 0,33 e 0,13), e uma menos cristalina (série 2), entre diagênese e anquizona (FWHM entre 0,64 e 0,30 ). A fase mais cristalina apresenta reflexões mais estreitas e de maior intensidade, posicionadas entre 8,923 e 8,703(20). Já a fase menos cristalina apresenta

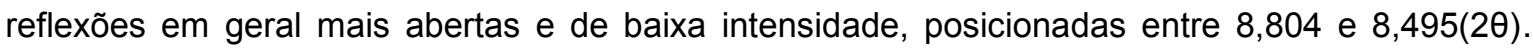
Não foi observada mudança significativa nos valores de FWHM das reflexões com maior grau de cristalinidade com a solvatação com etileno-glicol, indício que a presença de interestratificados é mínima. Para as reflexões com menor grau de cristalinidade, há uma variação significativa no tratamento com etileno-glicol. Estes dados são apresentados na figura 37.

Tabela 9 - Valores de FWHM após a decomposição. N - Fração argila seca ao ar; G - Fração argila solvatada com etileno-glicol.

\begin{tabular}{cccccc}
\multirow{2}{*}{ Amostra } & Granulometria & \multicolumn{2}{c}{$\mathbf{N}$} & \multicolumn{3}{c}{$\mathbf{G}$} \\
\cline { 3 - 6 } & & 1 & 2 & 1 & 2 \\
\hline 14-II-56 & $<2 \mu \mathrm{m}$ & 0,33 & 0,62 & 0,33 & 0,64 \\
\hline LS 002 & $<2 \mu \mathrm{m}$ & 0,238 & 0,494 & 0,241 & 0,478 \\
\hline LS 003 & $<2 \mu \mathrm{m}$ & 0,267 & 0,468 & 0,267 & 0,468 \\
\hline LS 004 & $<2 \mu \mathrm{m}$ & 0,298 & 0,468 & 0,298 & 0,468 \\
\hline $\mathbf{1 1 - I I I - 8 4}$ & $<2 \mu \mathrm{m}$ & 0,145 & 0,637 & 0,171 & 0,523 \\
\hline $\mathbf{1 2 - I V - 7 8}$ & $<2 \mu \mathrm{m}$ & 0,139 & 0,448 & 0,144 & 0,308
\end{tabular}




\begin{tabular}{cccccc} 
11-II-78 & $<2 \mu \mathrm{m}$ & 0,162 & 0,509 & 0,182 & 0,558 \\
\hline 13-V-1 & $<2 \mu \mathrm{m}$ & 0,181 & 0,412 & 0,168 & 0,386 \\
\hline 11-I-68 & $<2 \mu \mathrm{m}$ & 0,249 & 0,473 & 0,115 & 0,393 \\
\hline LS-006 & $<2 \mu \mathrm{m}$ & 0,21 & 0,45 & 0,235 & 0,633 \\
\hline LS-006 & $<0.2 \mu \mathrm{m}$ & 0,24 & 0,43 & 0,24 & 0,43 \\
\hline LS-007 & $<2 \mu \mathrm{m}$ & 0,18 & 0,36 & 0,165 & 0,369 \\
\hline LFDF 006 & $<2 \mu \mathrm{m}$ & 0,152 & 0,385 & 0,136 & 0,313 \\
\hline LFDF 006.2 & $<2 \mu \mathrm{m}$ & 0,159 & 0,432 & 0,167 & 0,39
\end{tabular}




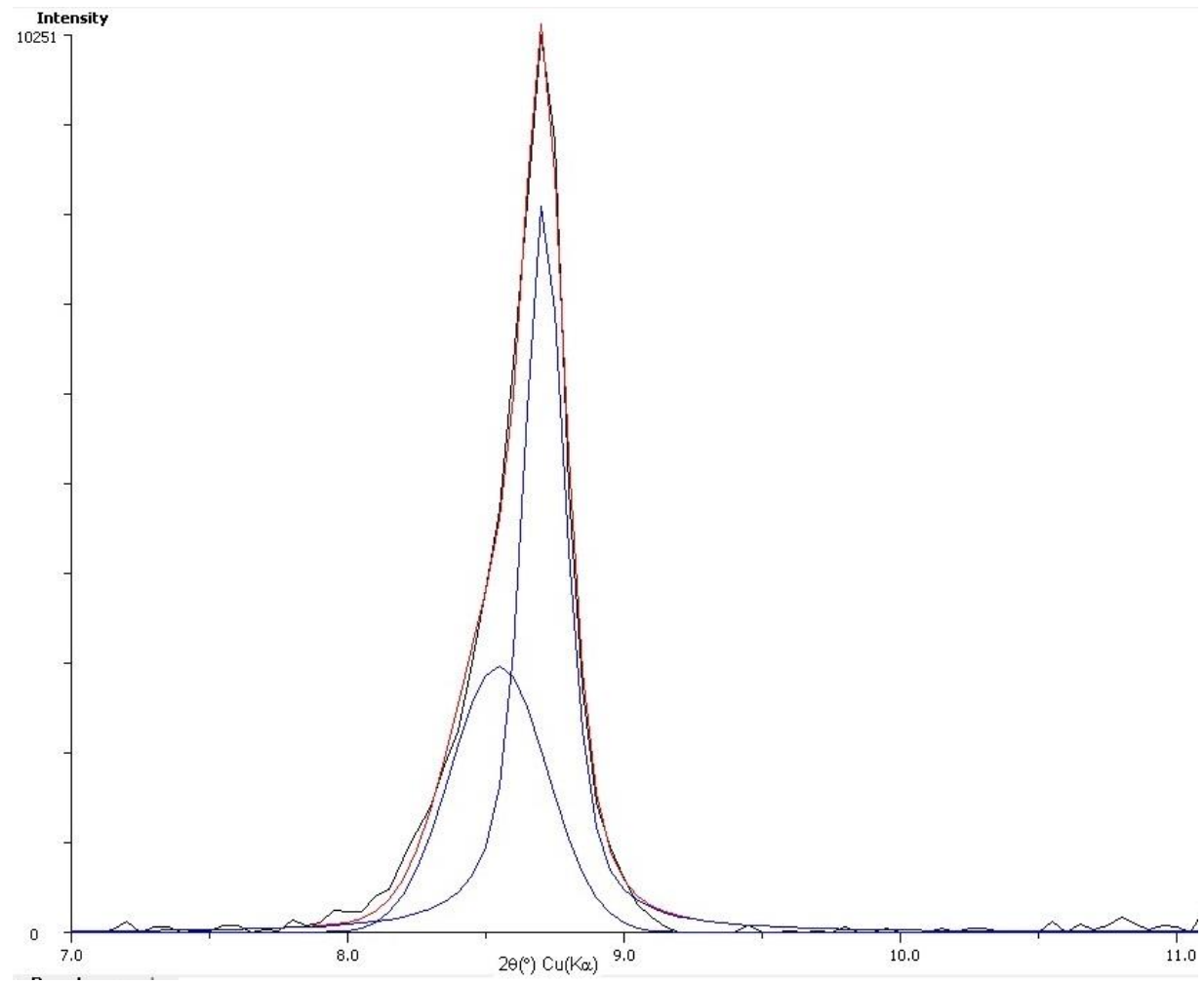

Figura 39 - Decomposição da reflexão 001 da illita da fração argila da amostra 13-V-1. A linha azul representa o valor medido. A linha vermelha representa a linha calculada que melhor se ajusta à reflexão. As linhas pretas representam as reflexões após a decomposição, a de maior intensidade correspondendo à série 1 e a de menor intensidade, à série 2 .

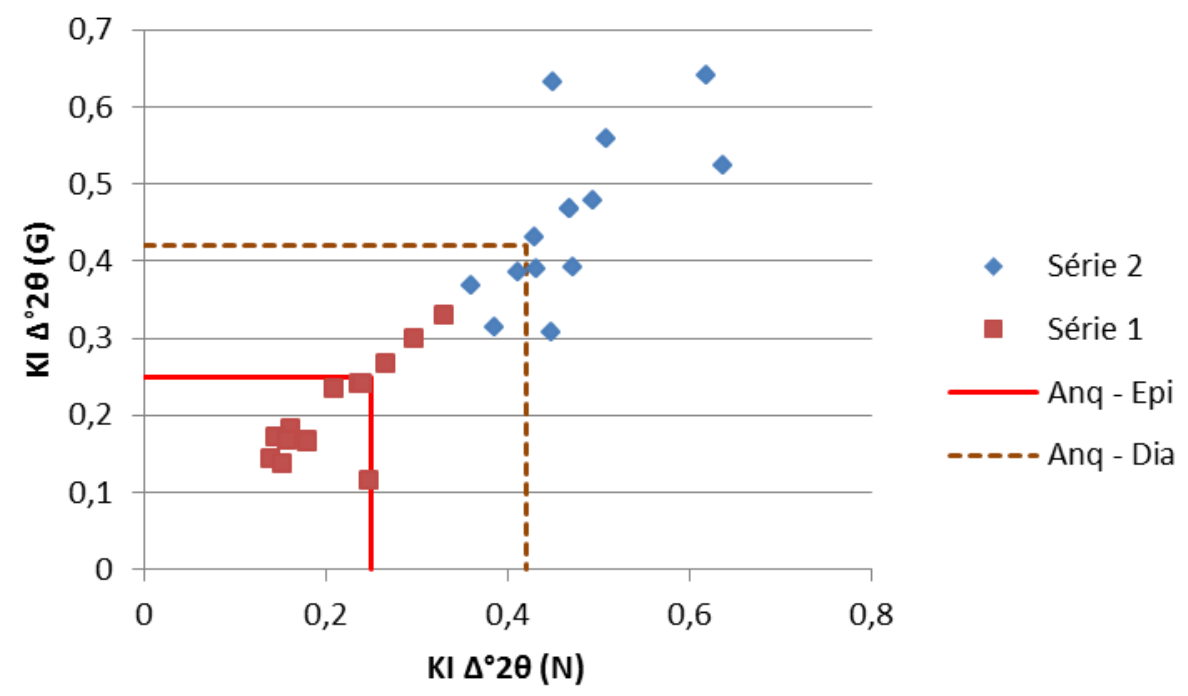

Figura 40 - Valores de FWHM da fração argila (N) versus valores de FWHM da argila solvatada com etileno-glicol $(G)$.

Assim como nos resultados pré-decomposição, foi observada uma tendência de diminuição dos valores em direção a oeste, no entanto, exibindo um grau diagenético mais baixo (figura 38). Tal efeito se deve provavelmente à retirada da influência do material detrítico. A amostra de Formosa-GO com FWHM 0,637 (11-III-84) apresenta sinais de alteração intempérica, provável motivo do valor mais alto. 


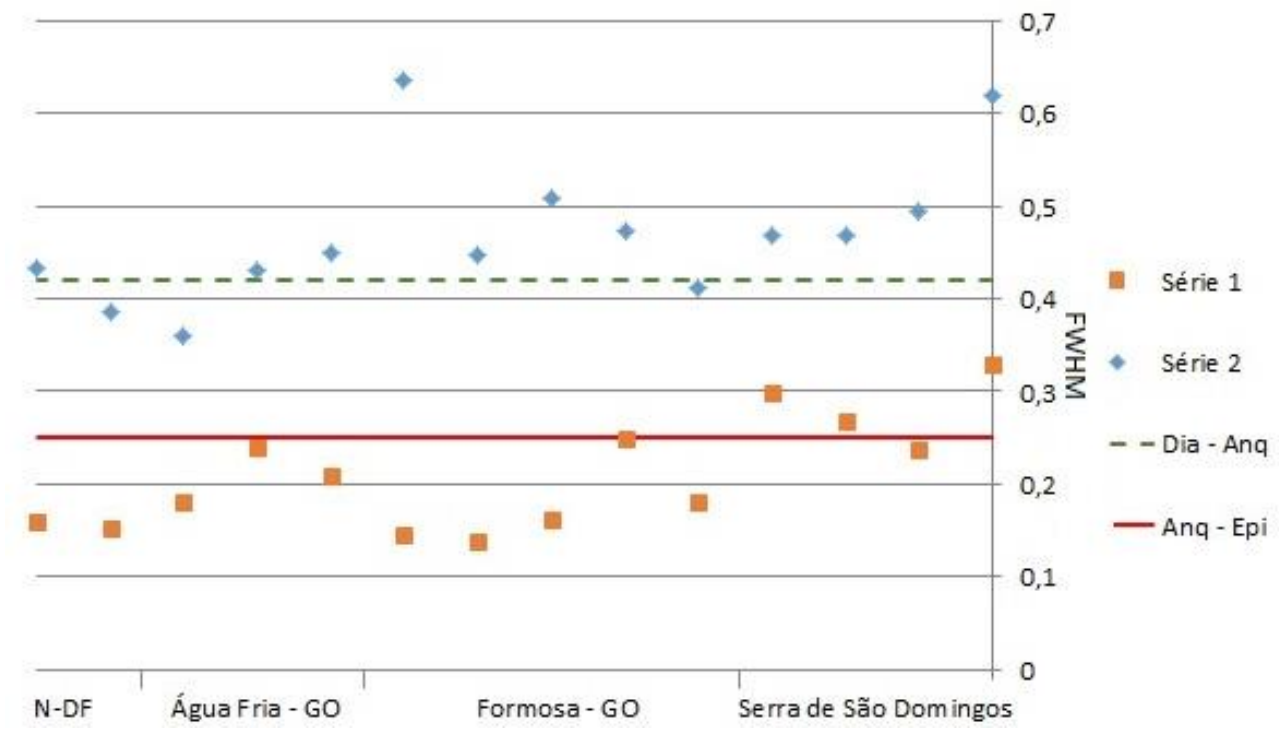

Figura 41 - Variação do índice de Kübler de acordo com a distância do Orógeno. Valores de FWHM em ${ }^{\circ} \Delta 2 \theta$.

\section{DISCUSSÃO: CONDIÇÕES DEPOSICIONAIS E DIAGENÉTICAS DA FORMAÇÃO SERRA DE SANTA HELENA, COM BREVES CONSIDERAÇÕES SOBRE A INFLUÊNCIA DA DESAGREGAÇÃO DE AMOSTRAS E A DETERMINAÇÃO DO ÍNDICE DE KÜBLER.}

As análises petrográficas e químicas forneceram dados que permitem interpretações sobre o contexto deposicional, enquanto as condições diagenéticas - indicadas pelas análises difratométricas, influenciadas, dentre outros fatores, pela forma de desagregação - foram determinadas pelo Índice de Kübler. Este por sua vez contou com a discriminação de constituintes detríticos e diagenéticos, pela utilização do software DECOMPX.

\subsection{Contexto deposicional}

A predominância da granulação fina e da laminação aproximadamente plano-paralela das rochas da FSSH indica deposição por decantação em massa de água com baixa energia, ocasionalmente perturbada pelo aporte de areias, cujas estruturas hummocky indicam eventos de tempestade. Perturbação dos sedimentos inconsolidados é registrada pelas estruturas de escorregamento, o que indica instabilidade do substrato.

Considerando a textura e, principalmente a composição, estas são rochas imaturas, com baixa intensidade de retrabalhamento, cujo conteúdo em matriz dos psamitos os enquadram na classificação de grauvacas. Estas grauvacas e os pelitos associados com porcentagem de quartzo, inferior a $50 \%$ (apenas uma com 53\%), tendo filossilicatos (micas e cloritas) como palhetas dispersas ou agregados atribuídos a litoclastos (em geral acima de 10\%), sendo o feldspato predominante o plagiocásio, são plotados no diagrama de Dickinson et al. (1983) no campo Orógeno Reciclado (figura 8).

O conteúdo relativamente baixo de quartzo e alto de plagioclásio e minerais máficos alterados para clorita (Figura 14) e vermiculita (Figuras 17 e 18) indica importante contribuição de rochas intermediárias a básicas como fonte dos sedimentos, isentas de alteração intempérica, em área muito próxima ao sítio de deposição.

Um aspecto intrigante da FSSH é a persistência em uma extensa área da composição mineral imatura bastante homogênea; no caso do presente estudo, desde a Serra de São Domingos (leste) até o município de Padre Bernardo (oeste).

Concordante com as características petrográficas das rochas da $\mathrm{FSSH}$, as análises químicas também mostram a composição de grauvacas, ou seja: conteúdo de $\mathrm{Na}_{2} \mathrm{O}$ em geral superior ao de $\mathrm{K}_{2} \mathrm{O}$ e de $\mathrm{MgO}$ superior ao de $\mathrm{CaO}$. Uma característica interessante a ser observada é a inversão da relação do sódio com o potássio com o princípio de intemperismo da rocha, quando o primeiro, por ser mais móvel, é lixiviado preferencialmente em relação ao último. 
As análises mostram que os psamitos da Formação Serra de Santa Helena apresentam características químicas que os enquadram na classificação das grauvacas: a predominância de $\mathrm{MgO}$ sobre $\mathrm{CaO}$ e, principalmente, de $\mathrm{Na}_{2} \mathrm{O}$ sobre $\mathrm{K}_{2} \mathrm{O}$. Em porcentagem de óxidos, a composição química destas se situa nos mesmos intervalos da composição de grauvacas citadas na literatura (Kozlowsky et al. 2014, Zimmermann 2005, Bauluz et al. 2000, El-Rahman et al. 2010, Pettijohn 1957b, tabela 1), observando-se conteúdos superiores de $\mathrm{Na}_{2} \mathrm{O}$ e $\mathrm{K}_{2} \mathrm{O}$. Com base na composição mineral (tabela 4), o sódio pode ser atribuído ao plagioclásio, enquanto o potássio está contido principalmente nas micas, mas também no feldspato potássico. Ferro e magnésio se encontram essencialmente nas cloritas, mas também podem ser associados à biotita, e o primeiro pode ainda estar contido na pirita e hematita.

A análise de elementos traço não gerou bons resultados, talvez em função do baixo limite de detecção do aparelho de fluorescência de raios-X. Poucos elementos deram resultado, e mesmo estes apresentaram valores muito superiores à média das rochas sedimentares, apresentada por Bathia \& Crook (1986). Uma análise mais confiável seria obtida utilizando-se ICPMS/AES.

O fato de que as rochas do Grupo Bambuí tenham tido sua proveniência classificada como Orógeno Reciclado se encaixa bem com a associação a uma bacia tipo foreland do Orógeno Brasiliano. Caso a matriz não fosse considerada como pseudomatriz, esta proveniência seria classificada como Continental Transicional/Interior Cratônico, o que não condiz com o contexto geotectônico regional. Tal resultado mostra também que, tal como apresentado na literatura, boa parte da matriz de grauvacas é proveniente da modificação diagenética de fragmentos líticos.

Os resultados da geoquímica, apesar de levemente discordantes, apontam para um ambiente de margem continental ativa, com contribuição de sedimentos de arco de ilhas e de sequências sedimentares/metassedimentares. O resultado do gráfico discriminante de Roser \& Korsch (1988), particularmente, reflete o mesmo tipo de informação obtida no diagrama petrográfico de Dickinson et al. (1983), indicando uma proveniência de terrenos granito-gnáissicos com possível contribuição de terrenos sedimentares. Tais resultados se encaixam no contexto da área-fonte dos sedimentos do Grupo Bambuí nesta porção da Faixa Brasília, possivelmente as rochas sedimentares/metassedimentares dos grupos Araxá, Canastra e Paranoá, e ígneas do Arco Magmático de Goiás.

\subsection{Condições diagenéticas ou de anquizona}

A determinação da diagênese/anquimetamorfismo é indicada pela presença/ausência de minerais expansivos e pelo Índice de Kübler. Para a determinação deste são recomendados procedimentos de preparação de amostras e condições analíticas (Kisch 1991, Árkai \& LelkesFelvári 1993 e Süssenberger et al. 2014), adotados no presente trabalho, que apresenta também a comparação de duas técnicas de desagregação de amostras: moinho micronizador McCrone e o morteiro.

\subsubsection{Desagregação de amostras}

A separação da fração argila é um procedimento essencial na análise dos argilominerais diagenéticos, tendo em vista que filossilicatos detríticos podem ter grande influência nas reflexões da illita e da clorita neoformadas. Além dos procedimentos adequados de separação, é essencial a aplicação da técnica de decomposição do pico d(001) para a discriminação de fases, cujas reflexões se sobrepõem, como no caso de micas/illita e de cloritas.

O moinho McCrone separou de modo eficiente os argilominerais nas amostras menos resistentes já que em um curto período de desagregação, foi liberada grande quantidade de material. Entretanto, para amostras mais resistentes, pode ocorrer a pulverização de minerais das frações mais grossas até o tamanho de $2 \mu \mathrm{m}$ ou menor. Para evitar esta pulverização, a maior eficiência do moinho McCrone é obtida diminuindo o tempo e aumentando a quantidade de ciclos de desagregação, separando periodicamente o material desagregado.

O morteiro proporcionou, de modo geral, uma desagregação menos agressiva, sendo que as reflexões dos argilominerais se tornaram tão intensas quanto as do quartzo, refletindo uma maior concentração dos primeiros em relação ao último. Isto pode se dever ao curto tempo de desagregação, que não permitiu a pulverização dos componentes de granulometria maior. 
6.2.2 Composição mineral definida por DRX

As análises difratométricas confirmam a composição definida pela petrografia, evidenciando os constituintes maiores da amostra e destacando a composição da fração argila.

A presença de vermiculita, esmectita e interestratificados pode ser associada com um princípio de alteração intempérica da própria rocha sedimentar e não como minerais indicadores de um estágio diagenético, como apontado por Bonhomme (1976), tendo em vista que as rochas em que foram identificados também apresentaram os maiores valores de CIA. Tais minerais, em especial a vermiculita, seriam formados logo no início do intemperismo, como resultado da alteração de minerais ferromagnesianos como clorita, biotita e anfibólio.

Apesar do avançado grau de alteração intempérica das amostras coletadas na região de Padre Bernardo, as análises por difratometria de raios-X revelaram mineralogia compatível com as descrições do Grupo Bambuí em outras regiões. Estudos mais aprofundados com enfoque em mapeamento geológico, petrografia e geoquímica são necessários, no entanto, para melhor definição do posicionamento estratigráfico destas rochas.

\subsubsection{Decomposição da reflexão 001 da illita/moscovita e Determinação do Índice de Kübler}

A discriminação das fases que contribuem para a reflexão 001 de illita/moscovita feita pela decomposição mostra a presença de dois picos: um mais estreito e intenso (FWHM entre 0,33 e 0,13 ) e outro mais largo e baixo (FWHM entre 0,64 e 0,30). Estes são interpretados respectivamente como mica detrítica e illita diagenética.

Tanto a análise de FWHM diretamente dos difratogramas quanto a realizada sobre o produto da decomposição mostram um leve aumento da cristalinidade da illita, e consequentemente do grau de diagênese/metamorfismo regional, em direção a oeste. Exceções a essa regra podem se dever a um grau mais elevado de alteração intempérica ou mesmo à influência de zonas de falha, que elevam localmente a temperatura e permitem uma melhor cristalização dos argilominerais. Com a realização de análises de mais amostras com maior distribuição pela região, é possível gerar um mapa onde zona diagenética, anquizona e epizona sejam bem definidas. Para tanto, a utilização da técnica de decomposição do pico d(001) de raios$X$ é essencial, pois fornece dados mais precisos e com menor influência de componentes detríticos e telodiagenéticos. Também é confirmada a influência das nappes do Grupo Canastra deformação sobre o estágio diagenético alcançado pelas rochas da Formação Serra de Santa Helena, visto que as amostras coletadas próximo ao contato com nappes do Grupo Canastra apresentaram os menores valores de FWHM, já em anquizona inferior.

As reflexões de menor valor de FWHM observadas se devem, provavelmente, a micas detríticas que não foram separadas durante o processo de desagregação e centrifugação. Tal afirmação é suportada pelo fato de que suas reflexões sofrem pouca ou nenhuma variação com o tratamento com etileno-glicol, característica de micas com alto grau de cristalinidade. Estas reflexões não podem ser associadas com illitas autigênicas, pois não foram observadas características petrográficas (foliações, mineralogia, etc) que suportem condições de epizona para estas rochas. A variação de seu FWHM pode ser associada a diferentes rochas-fonte, cada qual com diferentes níveis de diagênese/metamorfismo.

\section{CONSIDERAÇÕES FINAIS}

A partir das análises de petrografia, geoquímica e difratometria de raios- $X$, acrescida da técnica de decomposição do pico d(001), pode-se concluir que:

- Os resultados da geoquímica e da petrografia permitiram inferir o ambiente tectônicodeposicional e as rochas presentes na área-fonte dos sedimentos constituintes da Formação Serra de Santa Helena, que seriam um orógeno reciclado e terrenos formados por rochas máficasintermediárias, com contribuição expressiva de sequências sedimentares-metassedimentares. No entanto, para que tais resultados sejam melhor embasados e refinados é necessária a utilização de outras técnicas, como por exemplo geoquímica de elementos-traço e terras raras e estudos geocronológicos; 
- Os resultados apresentados pelo CIA indicam intemperismo moderado a alto na áreafonte, bem como enriquecimento em potássio em algumas amostras, com alteração telodiagenética como provável causa;

- O tipo de técnica utilizada na desagregação das amostras pode influenciar na quantidade de material detrítico misturado à fração argila. No entanto, mesmo que grande parte do material detrítico seja eliminado, a aplicação da decomposição ainda é essencial;

- O estágio diagenético alcançado pela Formação Serra de Santa Helena, indicado através da decomposição, foi de anquizona, e é mais alto quanto mais próximo do contato com as nappes do Grupo Canastra, evidenciando que a carga tectônica exerceu influência sobre a cristalinidade dos argilominerais. Exceções constituem zonas de falhas, onde o calor gerado pelo movimento pode elevar a cristalinidade dos argilminerais;

- A decomposição do pico $\mathrm{d}(001)$ dos difratogramas de raios-X constitui procedimento essencial na análise de FWHM em rochas sedimentares, visto que estas apresentam, na maioria dos casos, filossilicatos detríticos;

- É necessário um mapeamento geológico sistemático e detalhado da região de Padre Bernardo-GO, para esclarecimento e detalhamento da relação estratigráfica entre os grupos Bambuí, Paranoá e Canastra, bem como de suas respectivas subunidades;

\section{BIBLIOGRAFIA}

Abad, I. 2007. Physical meaning and applications of the illite Kübler Index: measuring reaction progress in low-grade metamorphism. Seminarios de la Sociedad Española de Mineralogía, 3, $53-64$.

Aldega, L., Botti, F. e Corrado, S. 2007. Clay mineral assemblages and vitrinite reflectance in the Laga Basin (Central Apennines, Italy): What do they record? Clays and Clay Minerals, 55, 504-518.

Alkmim, F.F. e Martins-Neto, M.A. 2001. A bacia intracratônica do São Francisco: arcabouço estrutural e cenários evolutivos. In: C.P. Pinto e M.A. Martins-Neto (editores). Bacia do São Francisco - Geologia e Recursos Naturais. SBG/Núcleo MG, p. 9-30.

Almeida, F.F.M. O Cratón do São Franscisco. 1977. Revista Brasileira de Geociências, 7(4):349364.

Almeida, F.F.M. O Cratón Paramirim e suas relações com o São Francisco. 1981. In: SBG, Simpósio sobre o Cratón do São Francisco e suas faixas marginais, Salvador, 1981. Anais, Salvador, p. 1-10.

Alvarenga, C.J.S. 1978. Geologia e Prospecção geoquímica dos grupos Bambuí e Paranoá na Serra de São Domingos - MG. Dissertação de Mestrado, IG-UnB.

Alvarenga, C.J.S.; Della Giustina, M.E.S.; Silva, N.G.C.; Santos, R.V.; Gioia, S.M.C.L.; Guimarães, E.M.; Dardenne, M.A.; Sial, A.N.; Ferreira, V.P. 2007. Variações dos isótopos de C e Sr em carbonatos pré e pós-glaciação Jequitaí (Esturtiano) na região de Bezerra-Formosa, Goiás. Revista Brasileira de Geociências, vol. 37(4-supl.), p. 147-155.

Alvarenga, C.J.S., Dardenne, M.A., Vieira, L.C., Martinho, C.T., Guimarães, E.M., Santos, R.V., Santana, R.O. 2012. Estratigrafia da borda ocidental da Bacia do São Francisco. Boletim de Geociências da Petrobrás, Rio de Janeiro, v.20, p. 145-164.

Alvarenga, C.J.S., Santos, R.V., Vieira, L.C., Lima, B.A.F., Mancini, L.H. 2014. MesoNeoproterozoic isotope stratigraphy on carbonates platforms in the Brasilia Belt of Brazil. Precambrian Research, 251, 164-180. 
Árkai, P. 1991. Chlorite crystallinity: an empirical approach and correlation with illite crystallinity, coal rank and mineral facies as exemplified by Palaeozoic and Mesozoic rocks of northeast Hungary. Journal of Metamorphic Geology, 9, p. 723-734.

Árkai, P. e Lelkes-Felvári, GY. 1993. The effects of lithology, bulk chemistry and modal composition on illite "crystallinity" -A case study from the Bakony Mts., Hungary. Clay Minerals28, p. 417-433.

Árkai P, Sassi FP, Sassi R (1995b) Simultaneous measurements of chlorite and illite crystallinity: a more reliable geothermometric tool for monitoring low- to very low-grade metamorphism in metapelites. A case study from Southern Alps (NE. Italy). European Journal of Mineralogy, 7:1115-1128.

Arkai, P., Faryad, S.W., Vidal, O., Balogh, K. (2003): Very low- grade metamorphism of sedimentary rocks of the Meliata Unit, Western Carpathians, Slovakia: Implications of phyllosilicate characteristics. International Journal of Earth Sciences, 92, p.68-85.

Barbosa, O. 1965. Série Bambuí. In: Congresso Brasileiro de Geologia, 19, 12p.

Battaglia, S., Leoni, L., Sartori, F. 2004. The Kübler index in the late diagenetic and low-grade metamorphic pelites: a critical comparison of data from the $10 \AA$ and $5 \AA$ peaks. Clays and Clay Minerals, 52, 85-105.

Bauluz, B.; Mayayo, M.J.; Fernandez-Nieto, C.; Lopez, J.M.G. 2000. Geochemistry of Precambrian and Paleozoic siliciclastic rocks from the Iberian Range (NE Spain): implications for sourcearea weathering, sorting, provenance and tectonic setting. Chemical Geology 168, p.135-150.

Bhatia, M.R., 1983. Plate tectonics and geochemical composition of sandstones. Journal of Geology, 91: 611-627.

Bhatia, M.R., Crook, K.A.W. 1986. Trace element characteristics of greywackes and tectonic setting discrimination of sedimentary basins. Contributions to Mineralogy and Petrology, 92:181-193.

Bisevac, V., Balogh, K., Balen, D., Tibilias, D. 2010. Eoalpine (Cretaceous) very low- to low-grade metamorphism recorded on the illite-muscovite-rich fraction of metasediments from South Tisia (eastern Mt Papuk, Croatia). Geologica Carpathica, 61, 6, 469—481.

Boggs, S. Jr. 2006. Principles of Sedimentology and Stratigraphy. Pearson Education Inc., $4^{\circ}$ ed. $662 \mathrm{p}$.

Boles, J.R., Franks, S.G., 1979, Clay diagenesis in Wilcox sandstones of Southwest Texas: implications of smectite diagenesis on sandstone cementation. Journal of Sedimentary Petrology, v. 49, p. 55-70.

Bonhome, M. 1976. Mineralogie des fractions fines et datations rubidium-strontium dans le Groupe Bambuí, MG, Brésil. Revista Brasileira de Geociências SBG, vol. 06, pp 211-222.

Braun, O.P.G. 1968. Contribuição à geologia do Grupo Bambuí. In: XXII CONGRESSO BRASILEIRO DE GEOLOGIA. Anais. Belo Horizonte: SBG, 1968, p.155-166.

Burley, S.D., Kantorovicz, J.D., Waugh, B. 1985. Clastic diagenesis. In: Sedimentology: Recent and Applied Aspects. P. Brenchley e B.P.B. Williams (editors). Special Publication of Geological Society of London, 18, p. 189-226.

Campos, L.F.B. 2013. Diagênese de sequências Proterozoicas com base na caracterização de argilominerais - topo do Grupo Paranoá e base do Grupo Bambuí - norte do Distrito Federal. Tese de Mestrado, Universidade de Brasília, Brasília-DF.

Campos, L.F.B., Guimarães, E.M., Barroso, R.H.G., Gomes, A.W. 2015. Influência da pressão e temperatura na cristalinidade da illita em sequências Proterozoicas: Norte do Distrito Federal e Goiás, Brasil. Brazilian Journal of Geology, 45(3): 383-398. 
Choquette, P.W. e Pray, L. 1970. Geologic nomenclature and classification of porosity in sedimentary carbonates. American Association Petroleum Geologists Bulletin, 54, 207-250.

COMIG/CPRM. 1999. Projeto São Francisco. Módulo I. Belo Horizonte. CD-ROM.

Costa M.T. \& Branco J.J.R. 1961. Introdução. In: Branco, J.J.R. (Ed.). Roteiro para a excursão Belo Horizonte - Brasília. In: SBG, Congresso Brasileiro de Geologia, Belo Horizonte, v. 15, p.1-119.

Crook, K.A.W. 1970b. Geotectonic significance of graywackes: Relevance of recent sediments from Niugini. $42^{\circ}$ ANZAAS Congress, Port Moresby, Niugini.

Curtis, C.D. 1977. Sedimentary geochemistry: environments and processes dominated by involvement of an aqueous phase. Philosophical transactions of the Royal Society, London, 286 , p. 353-372.

Dardenne, M.A. 1978. Síntese sobre a Estratigrafia do Grupo Bambuí no Brasil Central. XXX Congresso Brasileiro de Geologia, Recife, Anais, v.2, p. 597-610.

Dardenne M.A. 1979. Les mineralizations plomb, zinc, fluor du Protérozoique Supérieur dans le Brésil Central. These de Doctorat d'Etat, Université Pierre et Marie Curie - Paris VI. Paris, $251 \mathrm{p}$.

Dardenne, M.A. 2000. The Brasília Fold Belt. In: Cordani, U.G., Milani, E.J., Thomaz Filho, A., Campos, D.A. (Organizadores) Tectonic Evolution of South America, p. 231-263.

Dardenne, M.A. e Schobbenhaus, C. 2001. Metalogênese do Brasil. Brasília. Editora Universidade de Brasília, 392p.

Dickinson, W.R. 1985. Interpreting provenance relations from detrital modes of sandstones. In: Zuffa, G.G. (editor) Provenance of arenites, NATO-ASI Series, D. Reidel Publishing Company, v. 148: 333-361.

Drits, V.A., Lindgreen, H., Sakharov, B.A., Salyn, A.S. 1997. Sequence structure transformation of illite-smectite-vermiculite during diagenesis of Upper Jurassic shales, North Sea. Clay Minerals, 33, p.351-371.

Dunoyer de Segonzac G. 1969. Les minéraux argileux dans la diagenèse - passage au métamorphisme. Mémoires du Service de la Carte Géologique d'Alsace et de Lorraine, 29, $321 \mathrm{p}$.

El-Rahman, Y.A.; Polat, A.; Fryer, B.J.; Dilek, Y.; El-Sharkawy, M.; Sakran, S. 2010. The provenance and tectonic setting of the Neoproterozoic Um Hassa Greywacke Member, Wadi Hammamat area, Egypt: Evidence from petrography and geochemistry. Journal of African Earth Sciences 58, p. 185-196.

Fedo, C.M., Nesbitt, H.W., Young, G.M. 1995. Unraveling the effects of potassium metasomatism in sedimentary rocks and paleosols, with implications for paleoweathering conditions and provenance. Geology 10(23), p. 921-924.

Freitas-Silva F.H. \& Campos J.E.G. 1998. Geologia do Distrito Federal. In: IEMA/SEMATEC/UnB 1998. Inventário Hidrogeológico e dos Recursos Hídricos Superficiais do Distrito Federal. Brasília. IEMA/SEMATEC/UnB. Vol. 1, Parte I. 86p. (Relatório Inédito).

Frey, M. e Robinson, D. 1998. Low Grade Metamorphism. Blackwell Science, 313p.

Frey, M. 1987. Very Low-grade metamorphism of clastic sedimentary rocks. Em: Frey, M. 1987. Low Temperature metamorphism. Blackie and Son Ltda, Glasgow.

Fuck, R.A. 1994. A Faixa Brasília e a compartimentação tectônica na Província Tocantins. In: SBG/Núcleo Brasília e Centro Oeste. Anais do IV Simpósio de Geologia do Centro-Oeste, p. 184-187. 
Gomes, H.S. 1988. Contribuição à petrologia e à diagênese dos arenitos da Formação Três Marias, Bacia do São Francisco, MG. Anais do XXXV Congresso Brasileiro de Geologia, v. 2, Belém, p. 961-974.

Guimarães, D. e Dutra, C.V. 1969. Contribuição ao estudo da Série Bambuí. Boletim DNPM nº 243, Rio de Janeiro, 39p.

Guimarães, E.M., 1997. Estudos de proveniência e diagênese com ênfase na caracterização dos filossilicatos dos grupos Paranoá e Bambuí, na região de Bezerra - Cabeceiras (GO). UnB/Tese de Doutorado (inédito), pp 270.

Guimarães , E. M., Velde, B., Hiller, S. 2000. Diagenetic/ anchimetamorphic changes on the Proterozoic glauconite and glaucony from the Paranoa group mid-western Brazil. Brazilian Journal of Geology, 30 (3), p. 363-366.

Guimarães,E.M.; Dardenne,M.A.; Tonietto,S.N. 2004. Primeiros registros da emersão do Orógeno da FDB em Goiás: Formação Serra de Santa Helena. In: Congresso Brasileiro de Geologia, 42, Resumos.

Hillier, S., and Velde, B. (1991) Octahedral occupancy and the chemical composition of diagenetic (low-temperature) chlorites: Clay Miner. 26, 149-168.

Hower J. 1981. Shale diagenesis. In: Longstaffe FT, editor. Clays and the resource geologist. Short course handbook 7. Ottawa: Mineral Assoc Canada. p 60-80.

Hower, J., Eslinger, E. V., Hower, M. E., and Perry, E. A. (1976) Mechanism ofbufial metamorphism ofargillaceous sediments, 1. Mineralogical and chemical evidence: Geol. Soc. Amer. Bull. 87, 725-737.

Jaboyedoff, M., Bussy, F., Kübler, B., Thelin, Ph. 2001. Illite "Cristallinity" Revisited. Clays and Clay Minerals, 49(2), p. 156-167.

Kisch, H. J., 1983. Mineralogy and petrology of burial diagenesis (burial metamorphism) and incipiente metamorphism in clastic rocks. Em: Larsen, G., Chillingar, G. V. 1983. Diagenesis in sediments and sedimentar rocks, Elsevier, Amsterdam. Pp. 289-493.

Kisch, H. J., 1991. Illite crystallinity: recommendations on sample preparation, X-ray diffraction settings, and interlaboratory samples. Journal of metamorphic Geology, 9. 665 - 670.

Kozlowski, W.; Domanska-Siuda, J.; Nawrocki, J. 2014. Geochemistry and petrology of the Upper Silurian greywackes from the Holy Cross Mountains (central Poland): implications for the Caledonian history of the southern part of the Trans-European Suture Zone (TESZ). Geological Quarterly 58 (2), p. 311-336.

Kübler B. 1967. La cristallinité de l'illite et les zones tout á fait supérieurs de métamorphisme. Colloque sur les "Etages Tectoniques", 18-21. avrile 1966, Festschrift: p. 105-122, Neuchâtel.

Lacerda Filho, J.V.; Valente, C.R.; Bahia, R.B.C.; Lopes, R.C.; Romanini, S.J.; Oliveira, I.B.W.; Oliveira, C.C.; Sachs, L.L.B.; Silva, V.A.; Batista, I.H. 2004. Folha SD.22-Goiás. In: Schobbenhaus, C.; Gonçalves, J.H., Santos, J.O.S.; Abram, M.B.; Leão Neto, R.; Matos, G.M.M.; Vidotti, R.M.; Ramos, M.A.B.; Jesus, J.D.A. de. (eds). Carta Geológica do Brasil ao Milionésimo, Sistemas de Informações Geográficas-SIG. Programa Geologia do Brasil, CPRM, Brasília. CD-ROM.

Lanson, B. e Champion, D. 1991. The I/S-to-illite reaction in the late stage diagenesis. American Journal of Science, 291, 473-506.

Lanson, B. e Besson, G. 1992. Caracterization of the end of smectite-to-illite transformation: Decomposition of X-ray patterns. Clays and Clay Minerals, v. 40, n^1, 40-52.

Lanson, B. e Velde, B. 1992. Decomposition of X-ray patterns: A convenient way to describe complex I/S diagenetic evolution. Clays and Clay Minerals, v. 40, nº, 629-643 
Lanson, B. 1997. Decomposition of experimental X-ray diffraction patterns (profile fitting): A convenient way to study clay minerals. Clays and Clay Minerals, v.45, n², 132-146.

McLennan, S.M., Taylor, S.R., McCulloch, M.T. and Maynard, J.B. 1990. Geochemical and Nd-Sr isotopic composition of deep-sea turbidites: Crustal evolution and plate tectonic associations. Geochimica et Cosmochimica Acta, 54, 2015-2050.

Middleton, G. V., 1960, Chemical composition of sandstones. Geological Society of America Bulletin, 71, p. 1011-1026.

Nesbitt, H. W., and Young, G. M., 1982, Early Proterozoic climates and plate motions inferred from major element chemistry of lutites. Nature, 299, p. 715-717.

Nieto, F. 1998. Criterios de grado en la diagenesis y el metamorfismo incipiente. Conferencias. Sociedad Española de Arcillas (Ed. I. Palomo, M. Ortega y A. López Galindo), 119-128.

Pettijohn, F.J.; Potter, P.E.; Siever, R. 1987. Petrography of Common Sands and Sandstones. In: Sands and Sandstones. Second Edition. Berlim: Springer. 618p.

Pimentel M.M., Rodrigues J.B., Dellagiustina, M.E.S., Junges S.L., Matteini M., Armstrong R. 2011. The tectonic evolution of the Neoproterozoic Brasília Belt, central Brazil, based on SHRIMP and LA-ICPMS U-Pb sedimentary provenance data: A review. Journal of South American Earth-Sciences, 31: 345-357.

Potts, P.J. 1992. A Handbook of Silicate Rock Analysis. 2 ed. London, Glasgow. 70p.

RADAMBRASIL. Folha SD.23, Brasília. Levantamento de Recursos Naturais. Rio de Janeiro: MME. v. 29, 1982. 660 p.

Rimann, E.T. 1917. A kimberlita no Brasil. In: Anais da Escola de Minas, Ouro Preto, 15: 27-32.

Roser, B. P., and Korsch, R. J. 1986. Determination of tectonic setting of sandstones-mudstones suites using $\mathrm{SiO} 2$ content and K2O/Na2O ratio. Journal of Geology, 94, p. 635-650.

Santos, R.V., Alvarenga, C.J.S., Dardenne, M.A., Sial, A.N., Ferreira, V.P. 2000. Carbon and oxygen isotope profiles across Meso-Neoproterozoic limestones from central Brazil: Bambuí and Paranoá groups. Precambrian Research, 104, p. 107-122.

Santos, R.V., Alvarenga, C.J.S., Dardenne, M.A., Sial, A.N., Ferreira, V.P., 1997. A carbon isotope stratigraphic marker in the Bambuí Group, Brazil. South-American Symposium on Isotope Geology, 1, Anais, Campos do Jordão, Brazil, pp. 283-285.

Srodon, J. 1984. X-Ray Powder Diffraction identification of illitic materials. Clays and Clay Minerals, 32(5), p. 337-349.

Srodon, J., Paszkowski, M., Drygant, D., Anczkiewicz, A., Banas, M., 2013. Thermal history of Lower Paleozoic rocks on the Peri-Tornquist margin of the East European craton (Podolia, Ukraine) inferred from combined XRD, K-Ar and AFT data. Clays and Clay Minerals, 61 (2). 107-132.

Süssenberger, A., Neves, B.B.B., Wemmer, K. 2014. Dating low grade metamorphism and deformation of the Espinhaço Supergroup in the Chapada Diamantina (Bahia, NE Brazil): a KAr fine fraction study. Brazilian Journal of Geology. 44(2), 207-220.

Warr, L. N. \& Rice, A. H. N. 1994. Interlaboratory standardization and calibration of clay mineral crystallinity and crystallite size data. J. Metamorphic Geol, 12: 141 - 152.

Weaver, C.E. 1960. Possible uses for Clay Minerals in serach for Oil. American Association Petroleum Geology Bulletin, 44, 1505-1518.

Worden, R.H., Burley, S.D. 2003. Sandstone diagenesis: the evolution of sand to stone. In: Sandstone diagenesis: modern and ancient. Blackwell Publishing. 
Zimmermann, U. 2005. Provenance studies of very low to low grade metasedimentary rocks of the Puncoviscana complex, northwest Argentina. Geological Society, London, Special Publications, 246, p. 381-416. 
ANEXO I - DIFRATOGRAMAS DE RAIOS-X

Difratograma de Análise de rocha total (superior) e fração argila seca ao ar $(\mathrm{N})$, solvatada com etileno-glicol (G) e aquecida a $490^{\circ} \mathrm{C}(\mathrm{A})$ da amostra LS-001.
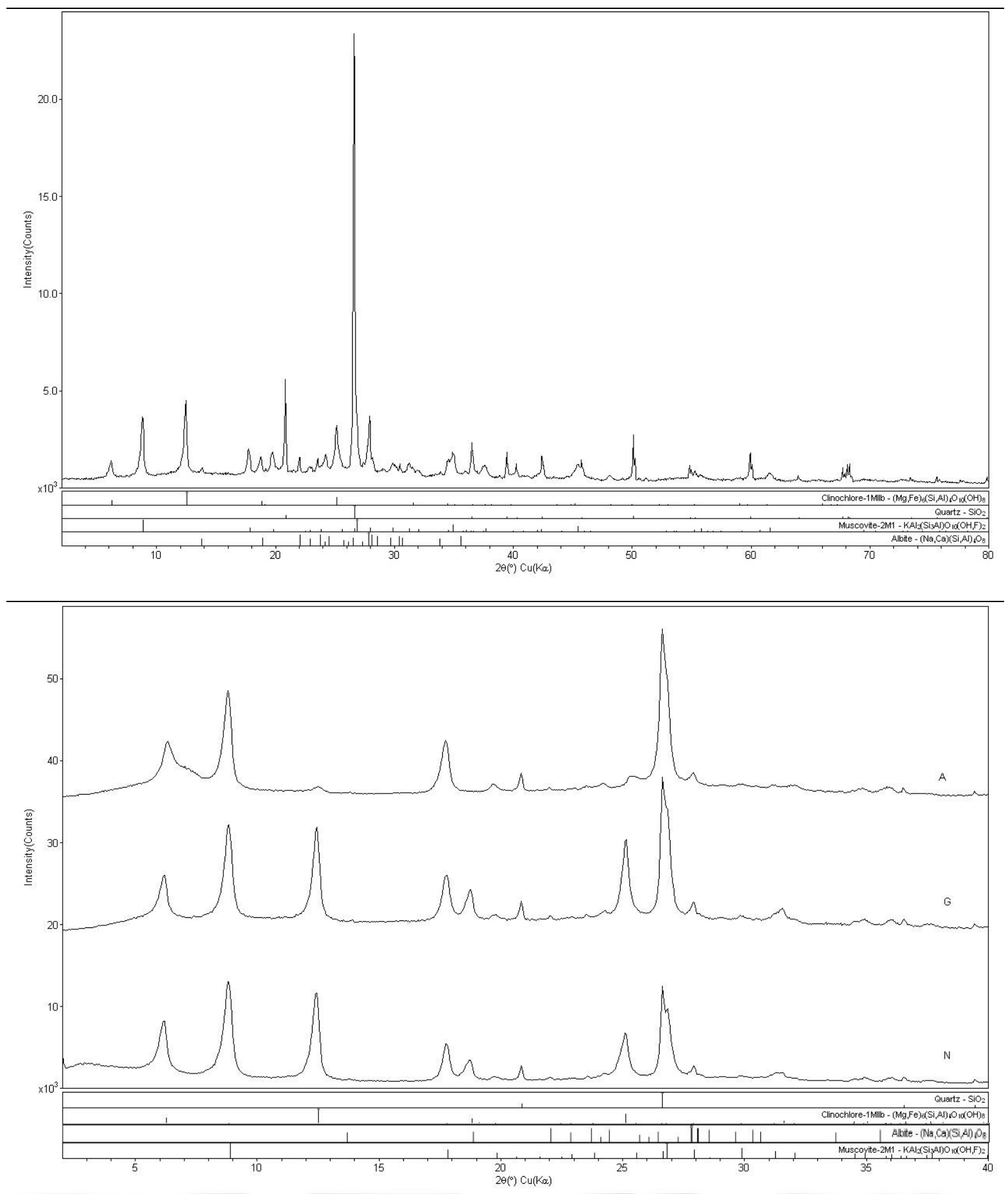
Difratograma de Análise de rocha total (superior) e fração argila seca ao ar $(\mathrm{N})$, solvatada com etileno-glicol (G) e aquecida a $490^{\circ} \mathrm{C}(\mathrm{A})$ da amostra LS-002.
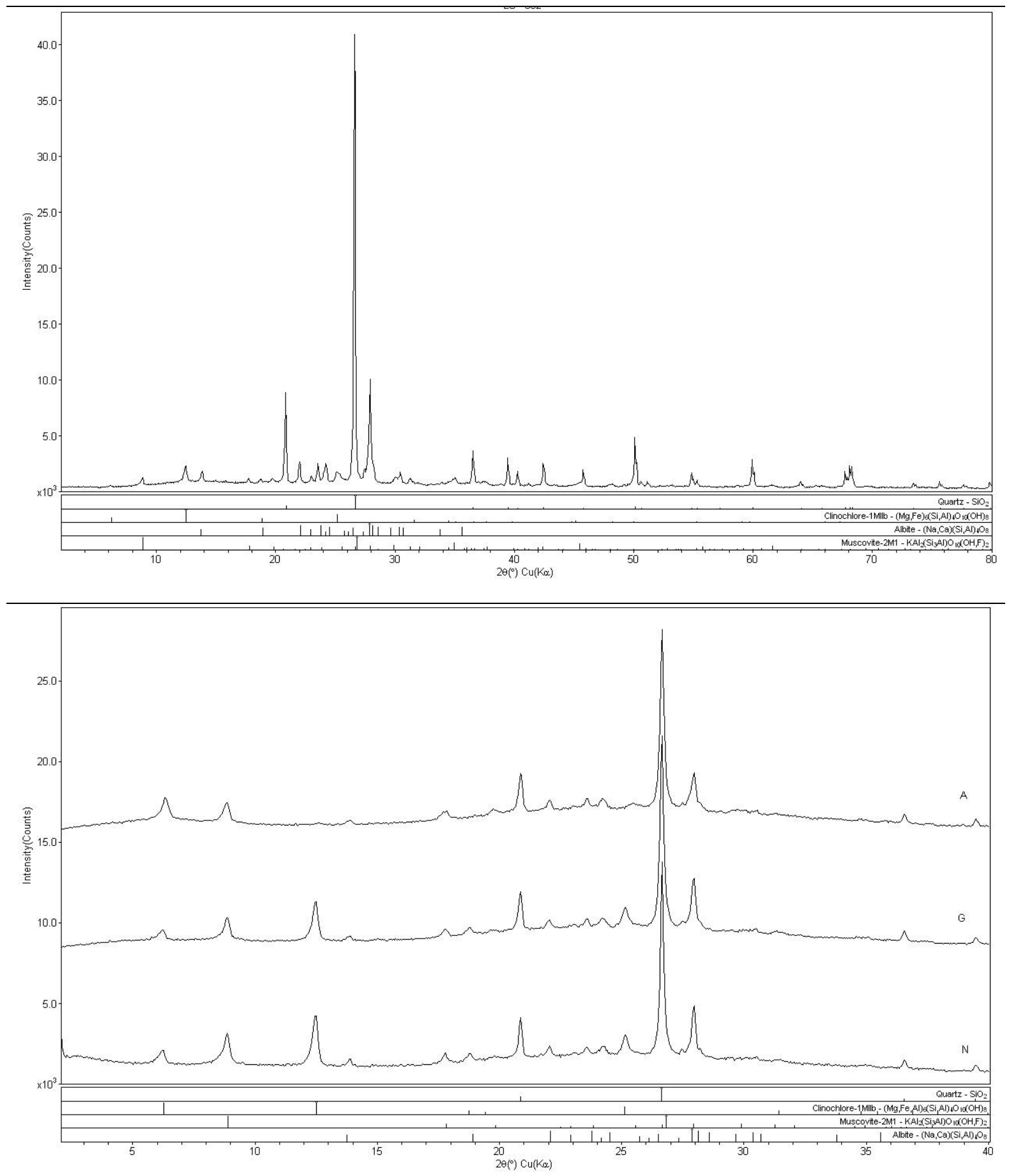
Difratograma de Análise de rocha total (superior) e fração argila seca ao ar $(\mathrm{N})$, solvatada com etileno-glicol (G) e aquecida a $490^{\circ} \mathrm{C}(\mathrm{A})$ da amostra LS-003.
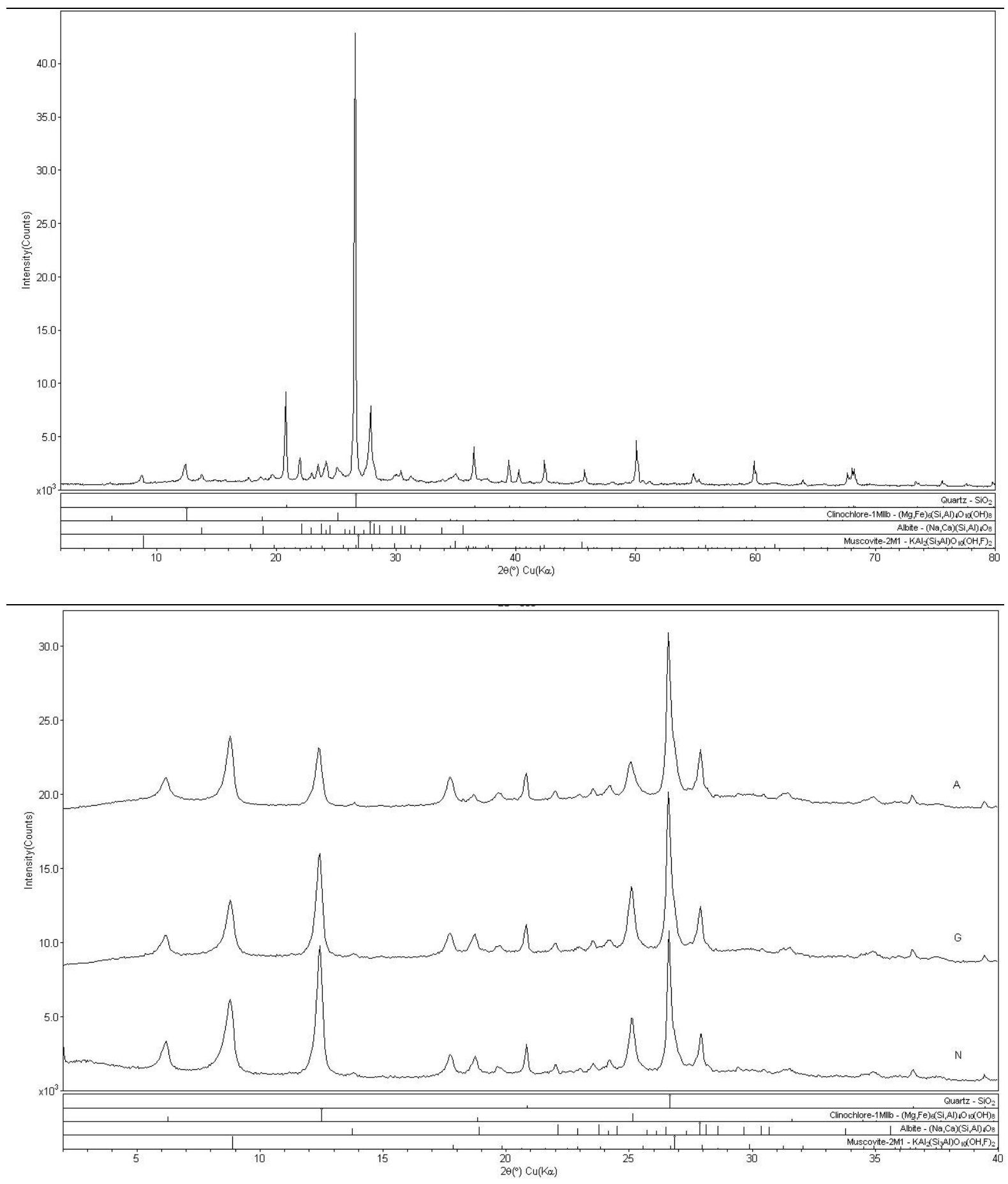
Difratograma de Análise de rocha total (superior) e fração argila seca ao ar $(\mathrm{N})$, solvatada com etileno-glicol (G) e aquecida a $490^{\circ} \mathrm{C}(\mathrm{A})$ da amostra LS-004.
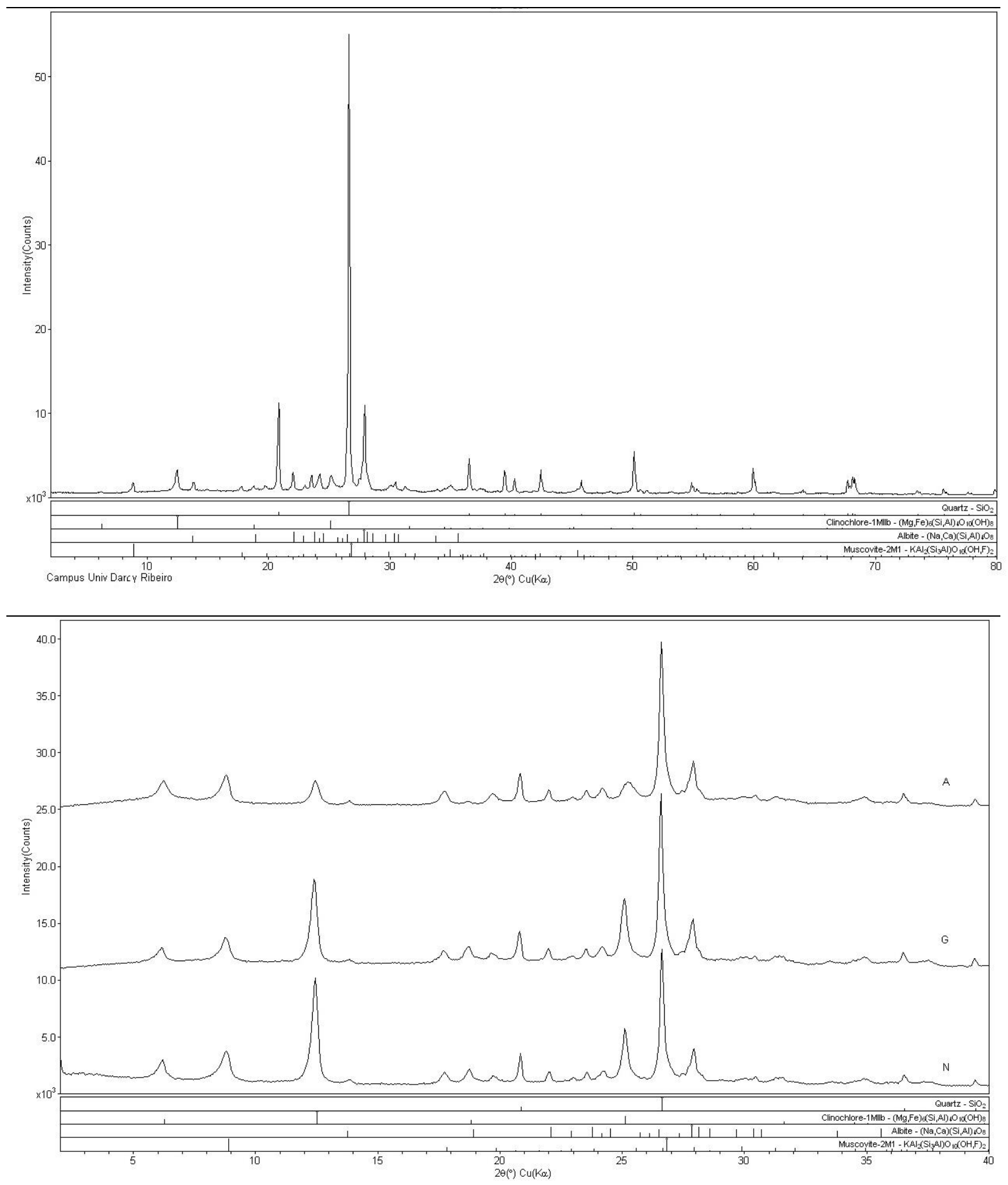
Difratograma de Análise de rocha total (superior) e fração argila seca ao ar $(\mathrm{N})$, solvatada com etileno-glicol (G) e aquecida a $490^{\circ} \mathrm{C}(\mathrm{A})$ da amostra LS-005.
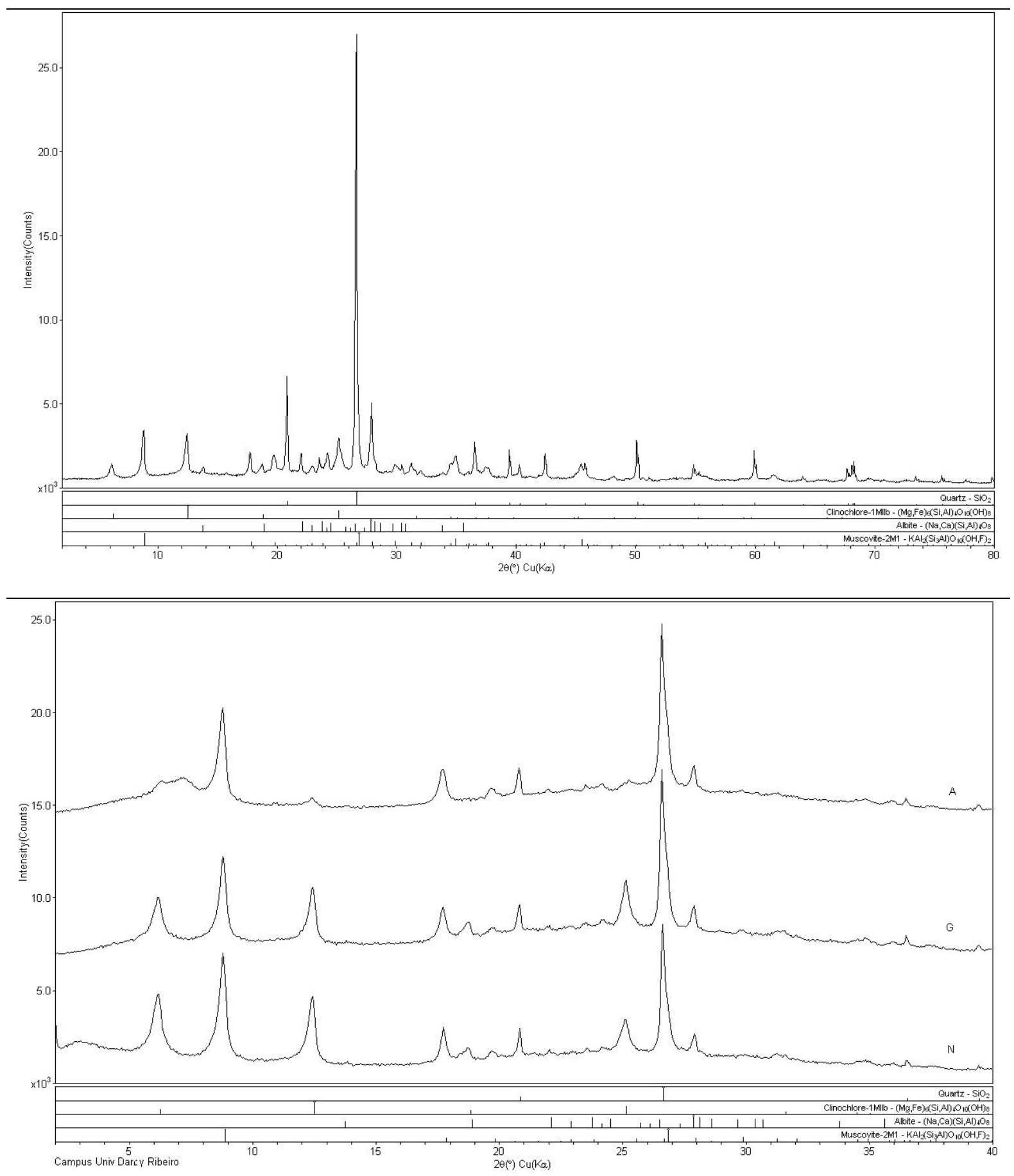
Difratograma de Análise de rocha total (superior) e fração argila seca ao ar $(\mathrm{N})$, solvatada com etileno-glicol (G) e aquecida a $490^{\circ} \mathrm{C}(\mathrm{A})$ da amostra LS-006.
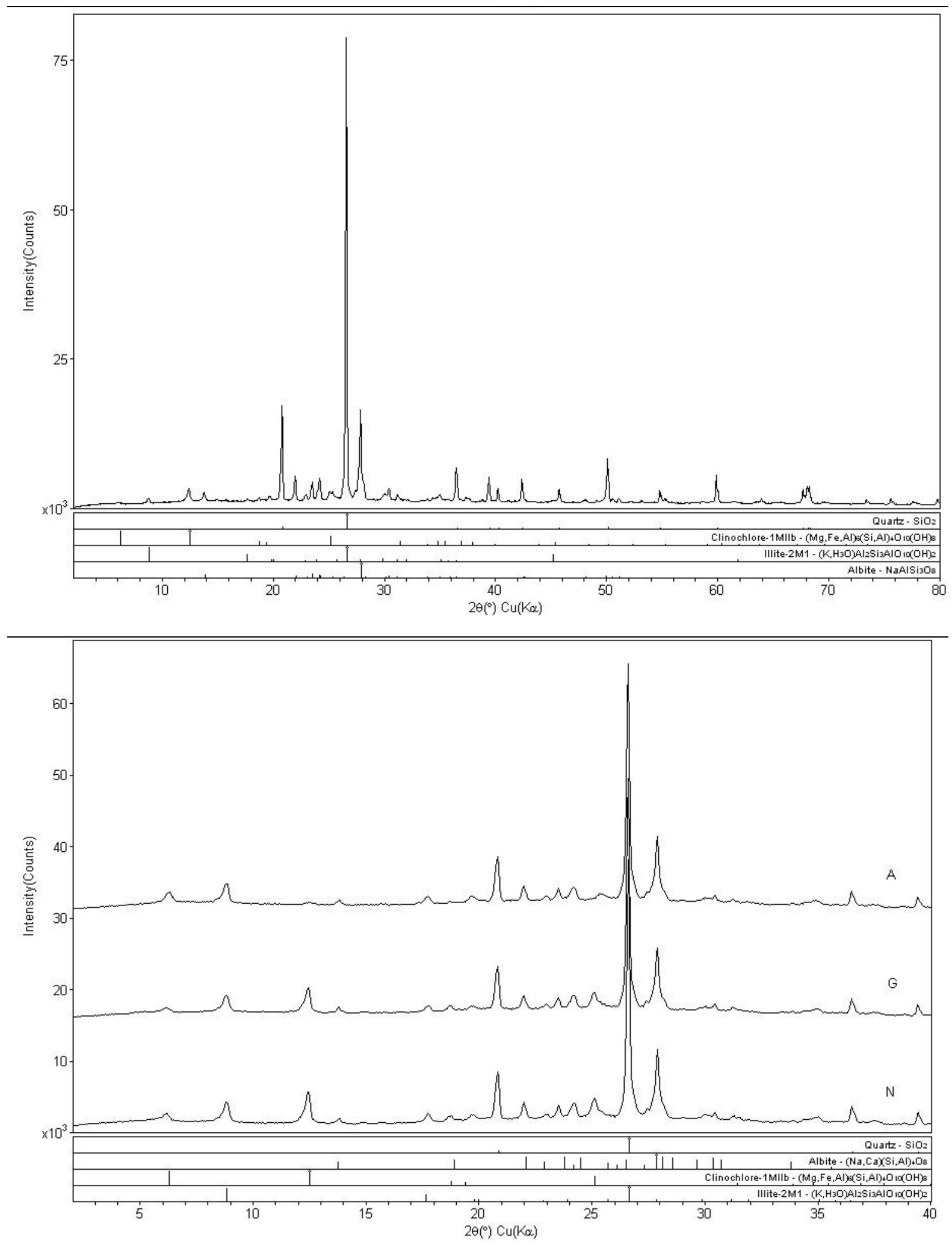
Difratograma de Análise de rocha total (superior) e fração argila seca ao ar $(\mathrm{N})$, solvatada com etileno-glicol (G) e aquecida a $490^{\circ} \mathrm{C}(\mathrm{A})$ da amostra LS-007.
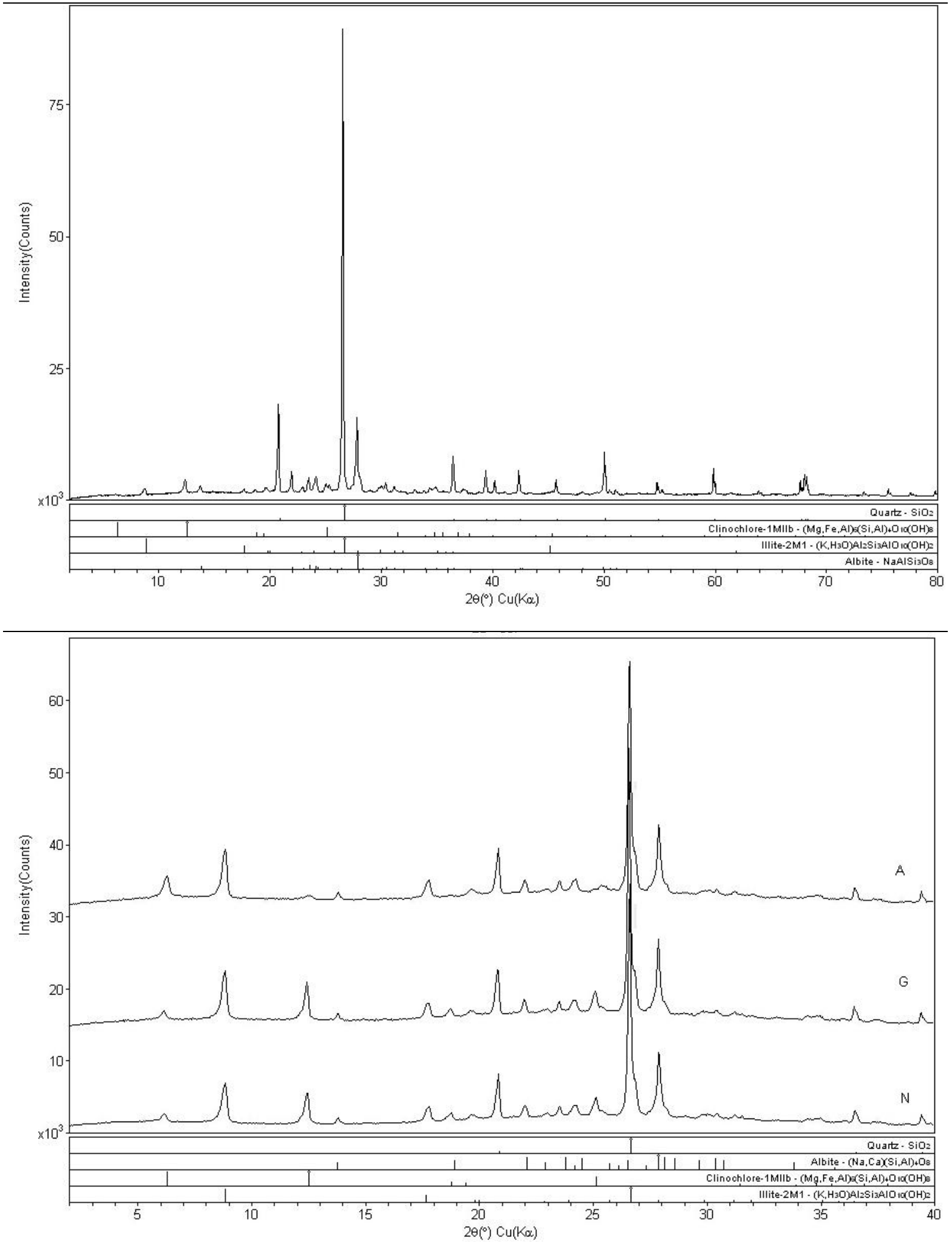
Difratograma de Análise de rocha total (superior) e fração argila seca ao ar $(\mathrm{N})$, solvatada com etileno-glicol (G) e aquecida a $490^{\circ} \mathrm{C}(\mathrm{A})$ da amostra LS-008a.
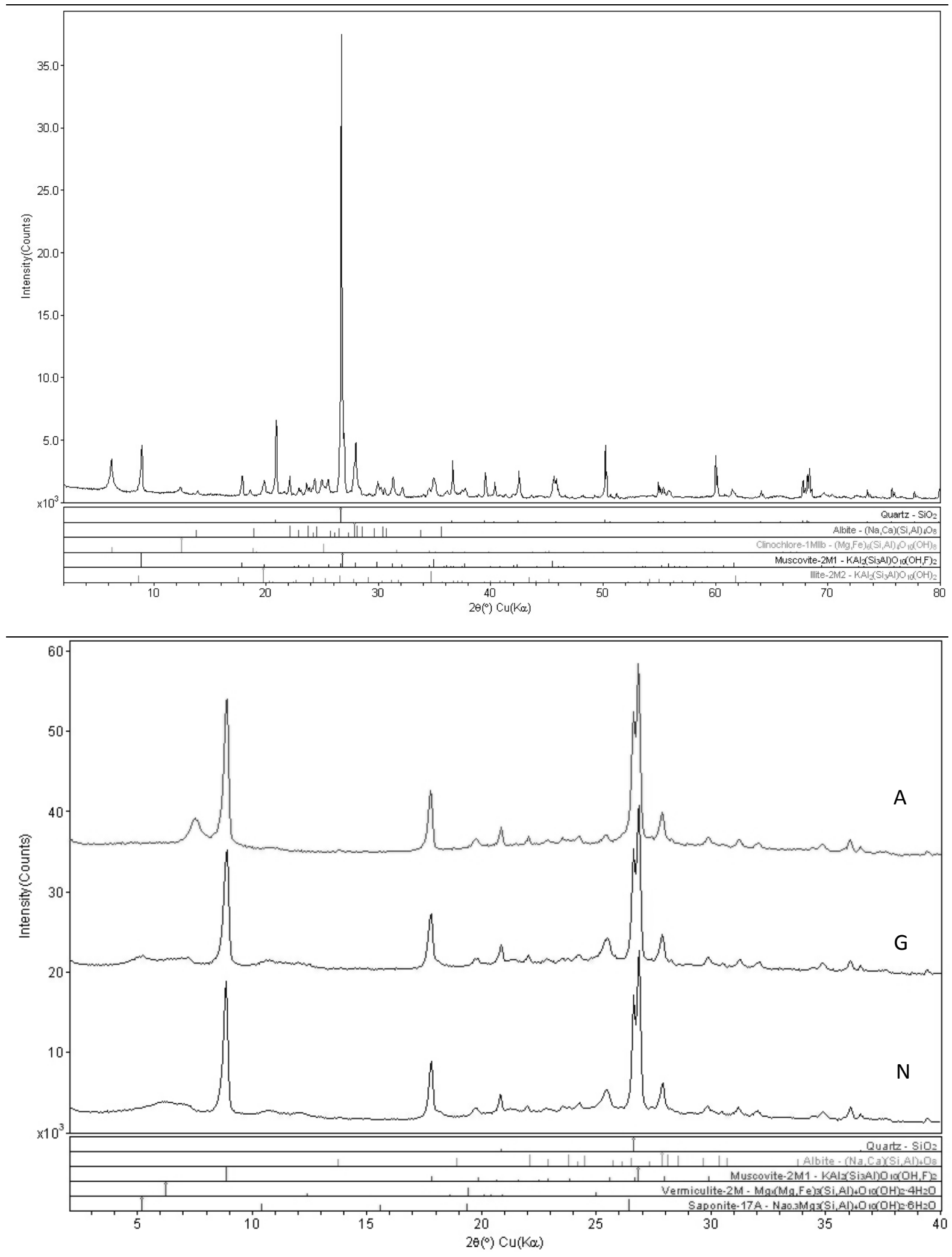
Difratograma de Análise de rocha total (superior) e fração argila seca ao ar $(\mathrm{N})$, solvatada com etileno-glicol (G) e aquecida a $490^{\circ} \mathrm{C}(\mathrm{A})$ da amostra LS-008b.
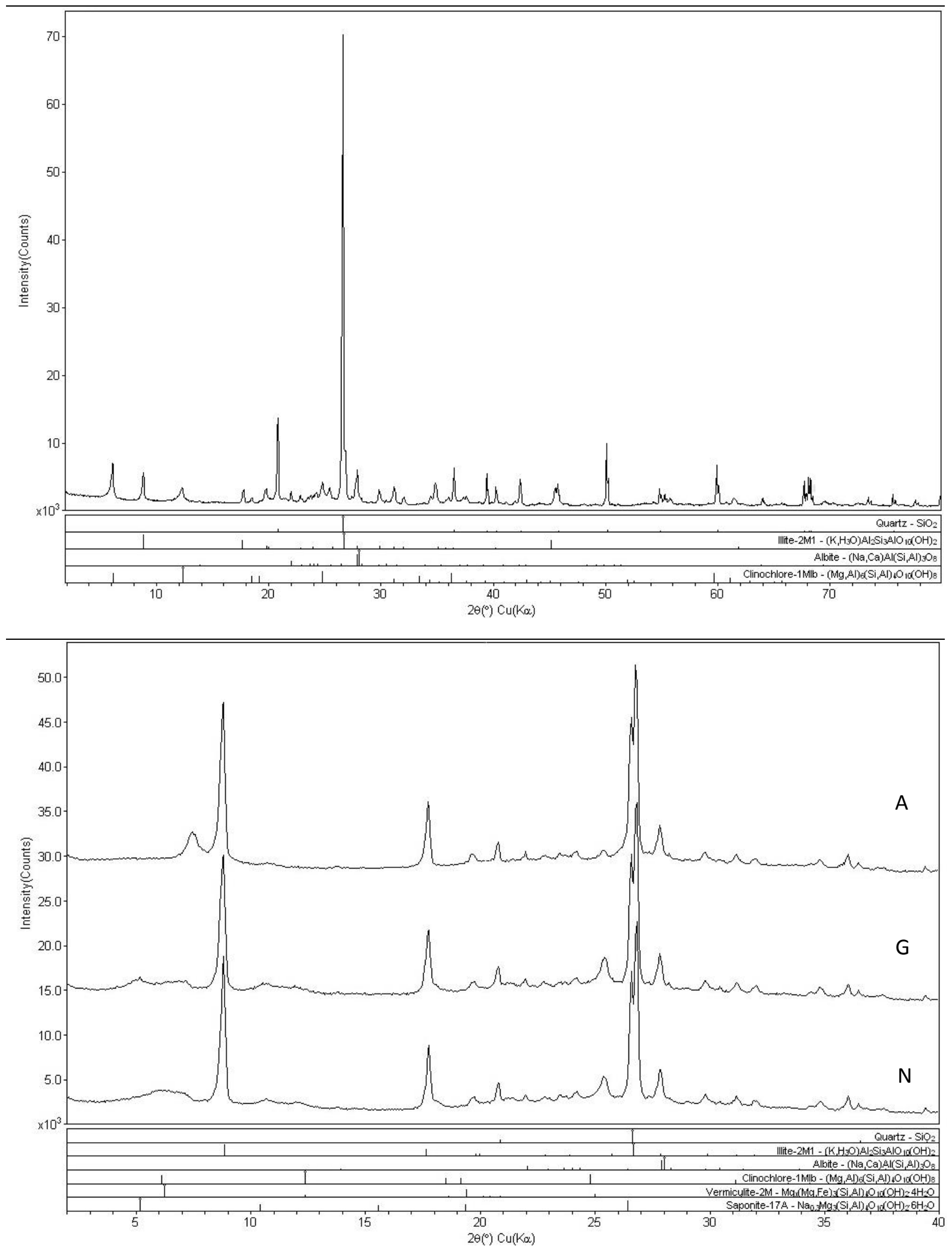
Difratograma de Análise de rocha total (superior) e fração argila seca ao ar $(\mathrm{N})$, solvatada com etileno-glicol (G) e aquecida a $490^{\circ} \mathrm{C}(\mathrm{A})$ da amostra 11-I-68.
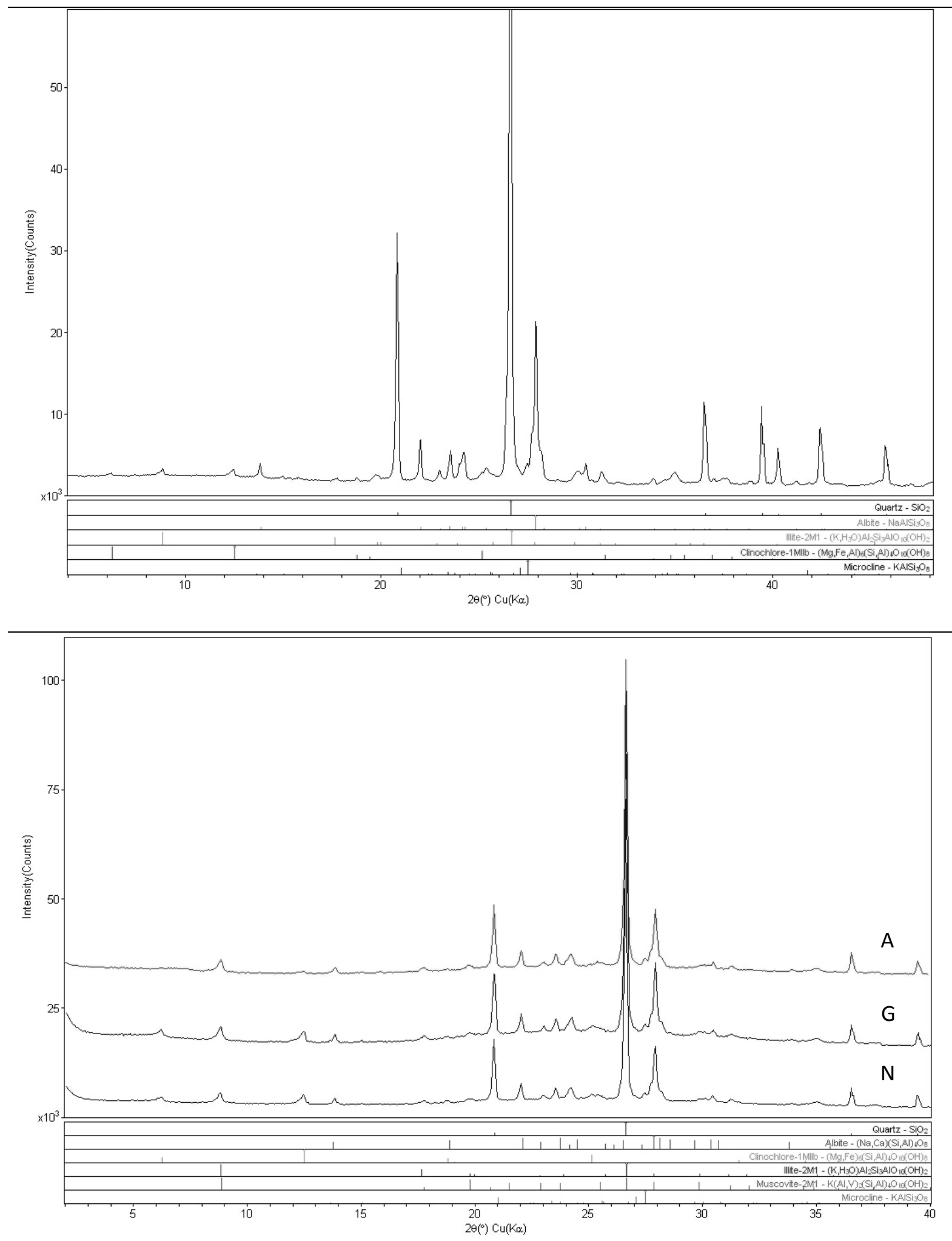
Difratograma de Análise de rocha total (superior) e fração argila seca ao ar $(\mathrm{N})$, solvatada com etileno-glicol (G) e aquecida a $490^{\circ} \mathrm{C}(\mathrm{A})$ da amostra 12-IV-78.
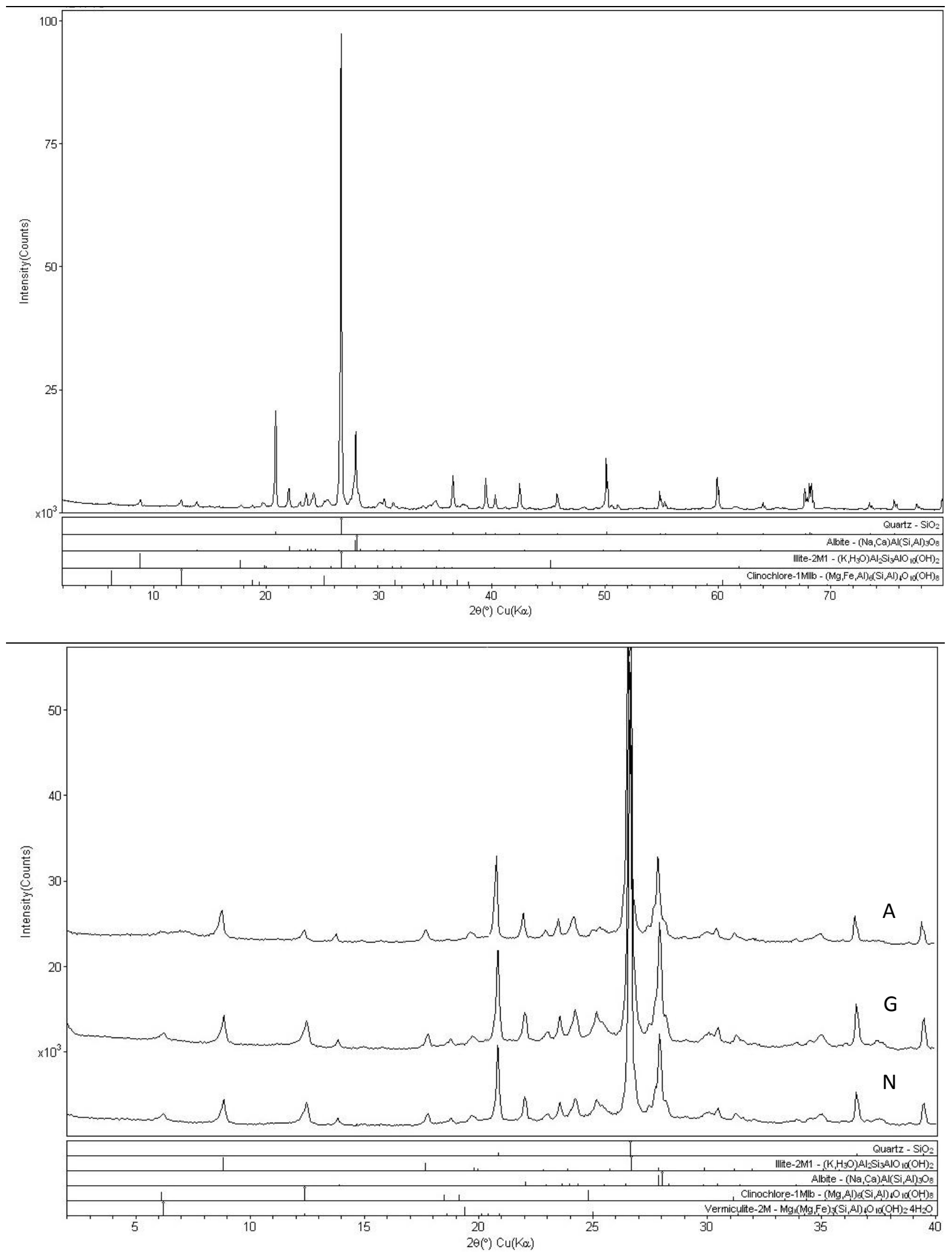
Difratograma de Análise de rocha total (superior) e fração argila seca ao ar $(\mathrm{N})$, solvatada com etileno-glicol (G) e aquecida a $490^{\circ} \mathrm{C}(\mathrm{A})$ da amostra $13-\mathrm{V}-1$.
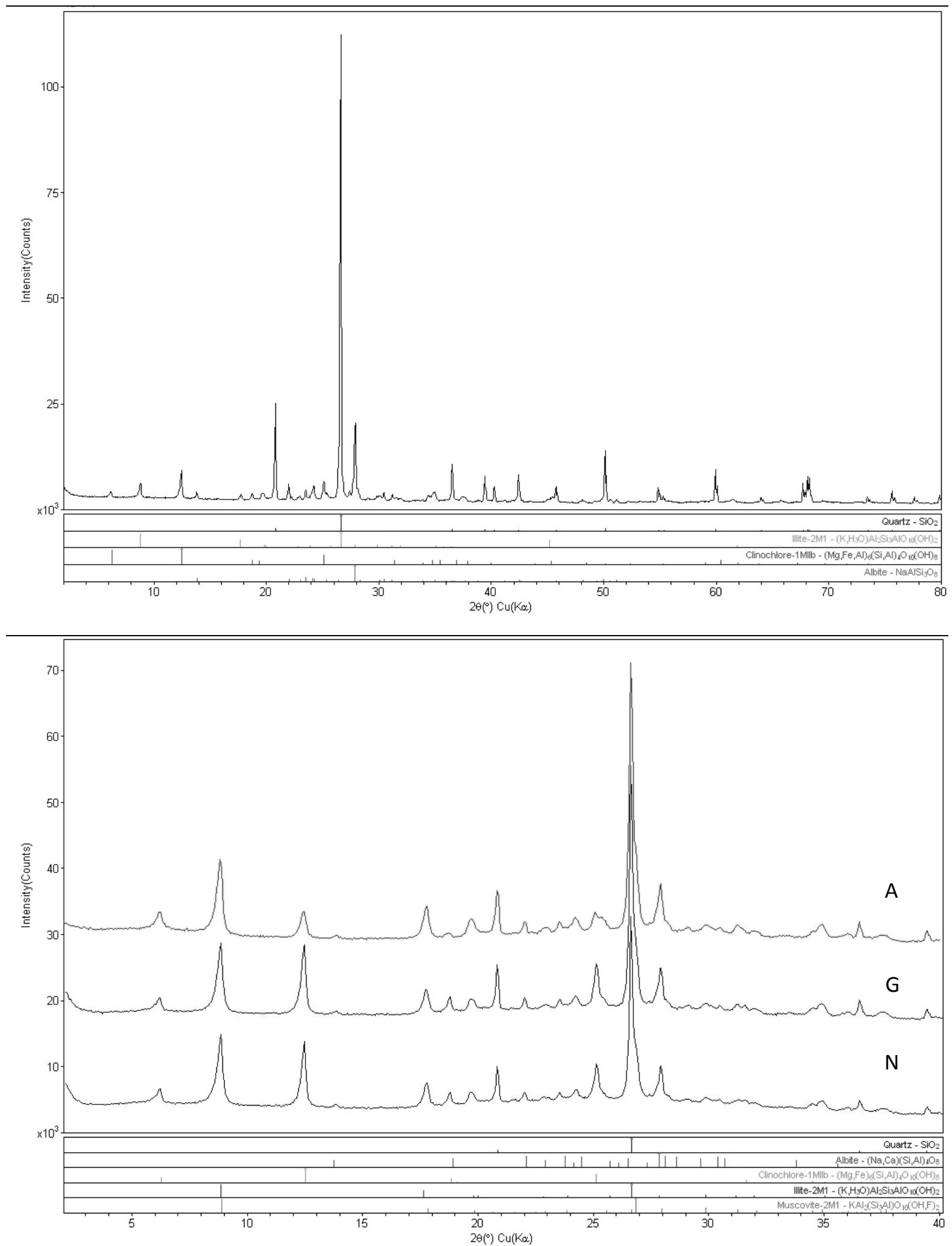
Difratograma de Análise de rocha total (superior) e fração argila seca ao ar $(\mathrm{N})$, solvatada com etileno-glicol (G) e aquecida a $490^{\circ} \mathrm{C}(\mathrm{A})$ da amostra 14-II-56.
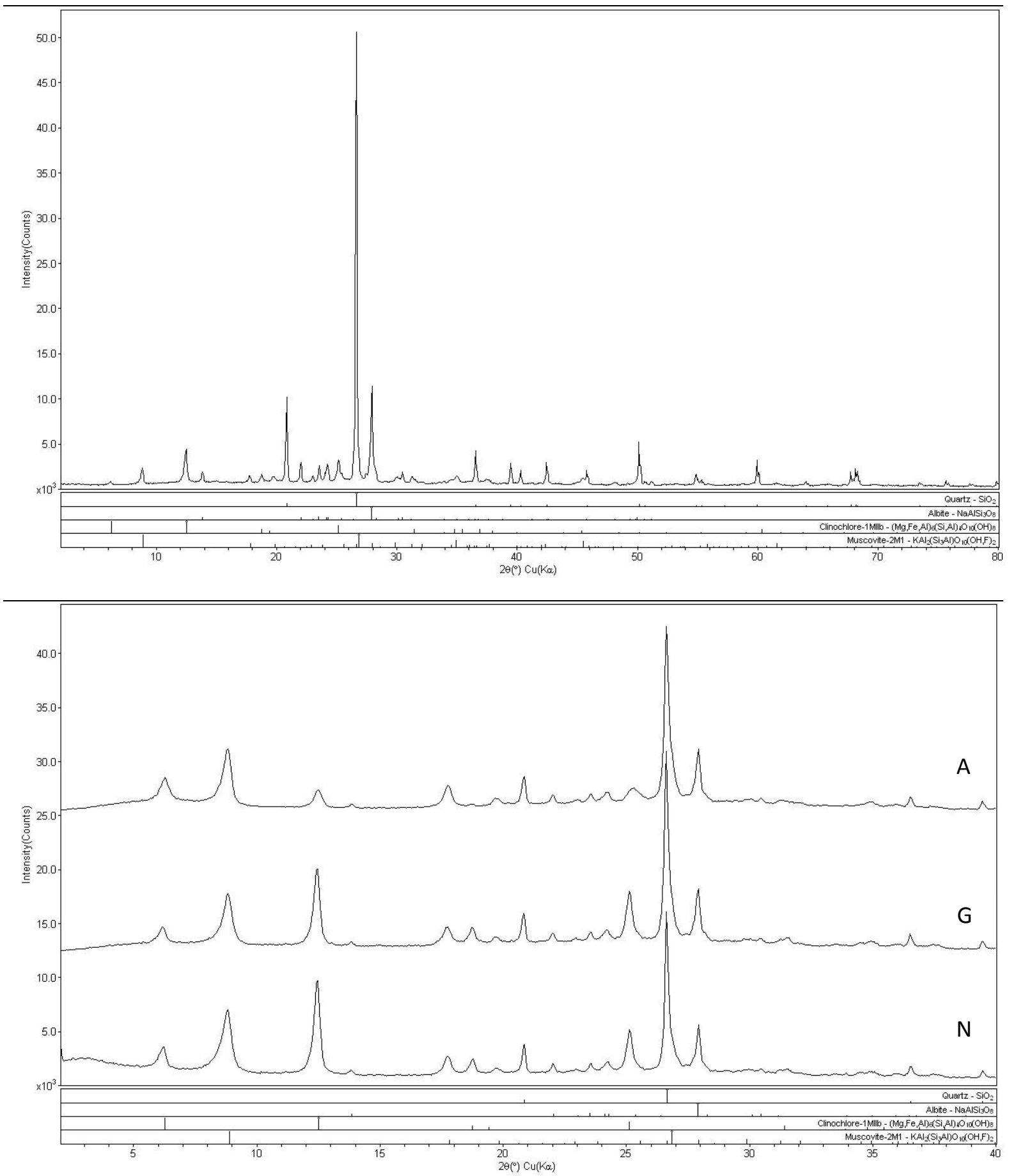
Difratograma de Análise de rocha total (superior) e fração argila seca ao ar $(\mathrm{N})$, solvatada com etileno-glicol (G) e aquecida a $490^{\circ} \mathrm{C}(\mathrm{A})$ da amostra 11-II-78.
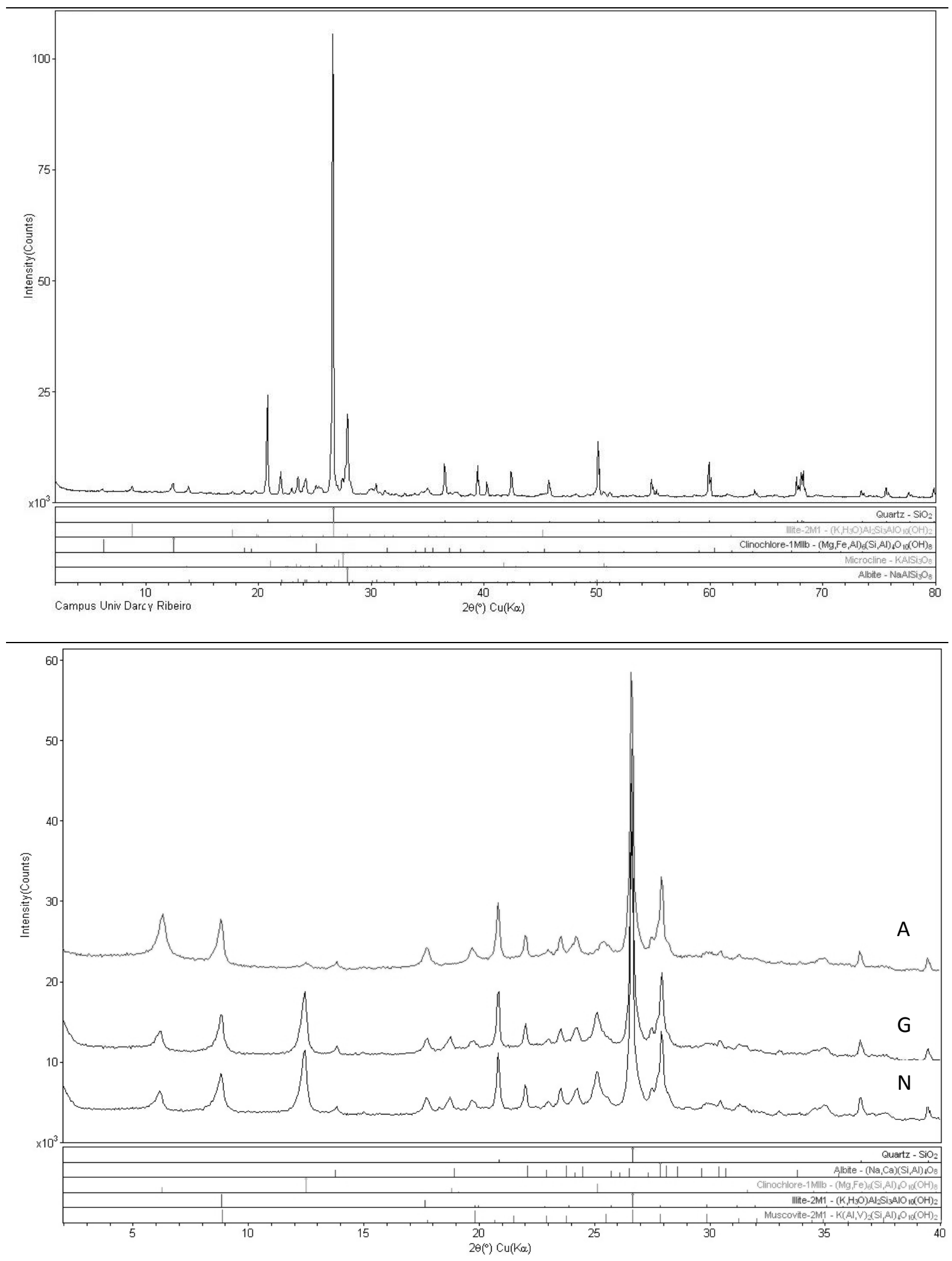
Difratograma de Análise de rocha total (superior) e fração argila seca ao ar $(\mathrm{N})$, solvatada com etileno-glicol (G) e aquecida a $490^{\circ} \mathrm{C}(\mathrm{A})$ da amostra $11-\mathrm{III}-84$.
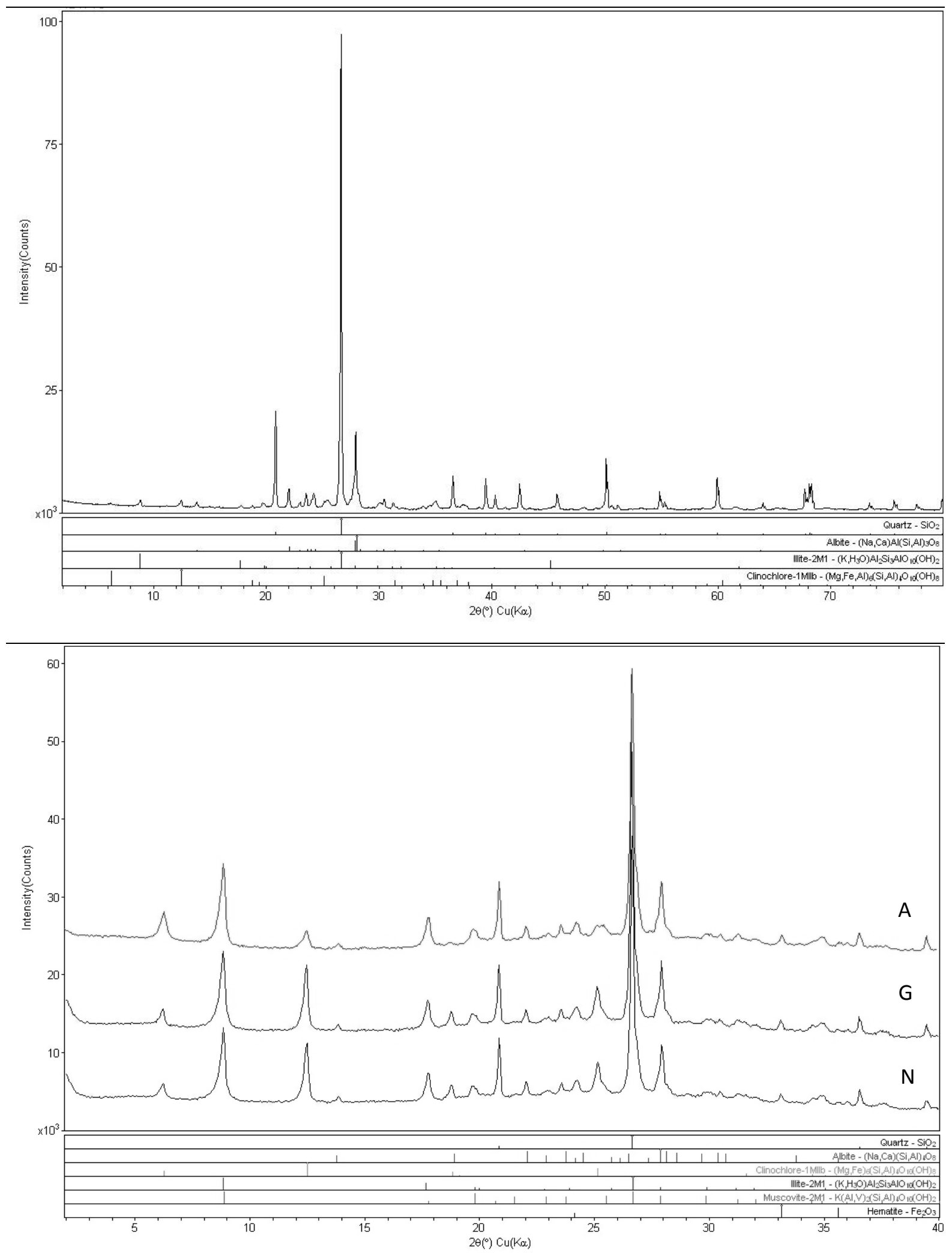